UNIVERSIDADE DE SÃO PAULO

INSTITUTO DE GEOCIÊNCIAS

\title{
A GEOLOGIA DO MACIÇO SIENÍTICO DA PEDRA BRANCA, CALDAS - MG
}

ANDREAS ANTONIUS MARIA WINTERS

Dissertação de Mestrado apresentada ao Instituto de Geociências da Universidade de São Paulo.

SÃO PAULO

1981 


\section{UNIVERSIDADE DE SÃO PAULO}

INSTITUTO DE GEOCIÊNCIAS

\section{A GEOLOGIA DO MACIÇO SIENÍTICO DA PEDRA BRANCA, CALDAS - MG}

ANDREAS ANTONIUS MARIA WINTERS

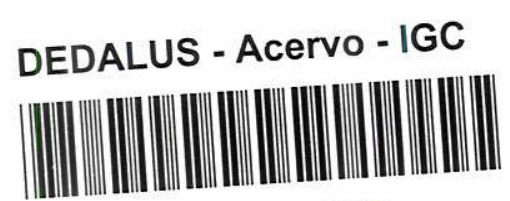

30900005920
Dissertação de Mestrado apresentada ao Instituto de Geociências da Universidade de São Paulo.

\section{Orientador:}

Prof. Dr. José Moacyr Vianna Coutinho

SÃO PAULO

1981 
Aos meus Pais, Esposa e

Filhos. 
I. INTRODUÇAOO 1

I. T. Justificativa do tema 1

I.1.1. Histörico 1

I.1.2. Importāncia 2

1.2. Caracterização da ārea 3

I.2.1. Localização 3

I.2.2. Vias de acesso 3

I.2.3. CTima 3

I.2.4. Vegetação 5

I.2.5. Economia 5

I.3. Metodologia 5

A. Trabalhos de Campo 6

B. Trabalhos de Laboratōrio 6

1. Determinações Microscōpicas 6

a. Determinação qualitativa 6

b. Determinação quantitativa 7

c. Estudo atravēs da Platina de Federoff 7

2. Determinações Radiomētricas 8

C. Trabathos Finais de Escritōrio 9

II. GEOLOGIA REGIONAL 10

A. Complexo de Silvianópolis 13

B. Grupo Amparo 13

C. Grupo Pinhal 13

D. Formações Eleutērio e Pouso Alegre 18

E. Maciço Alcalino de Poços de Caldas 18

III. GEOMORFOLOFIA 20

III. 1. Anālise do Relevo 20

III.1.1. Area Serrana 20

III.1.2. Area de "Mares de Morros" 21

III.2. Anālise da Rede de Drenagem 22 
IV. GEOLOGIA LOCAL 24

IV.T. Migmatitos 24

IV.1.1. Forma e Dimensões 24

IV.1.2. Correspondência Geomorfolögica 24

IV.7.3. Relações de Contato 24

IV.1.4. Litologia 24

IV.2. Granitos Porfirōides e Equigranulares 25

IV.2.1. Forma e Dimensões 25

IV.2.2. Correspondēncia Geomorfolögica 26

IV.2.3. Contatos 26

IV.2.4. Litologia 26

IV.2.4.1. Granitos porfiröides 26

IV.2.4.2. Granitos equigranulares 27

IV.3. O Maciço Sientitico da Pedra Branca 27

IV.3.1. Forma e Dimensões 27

IV.3.2. Correspondência Geomorfolōgica 28

IV.3.3. Contatos Externos do Maciço Sienîtico 28

IV.3.3.1. Com o maciço alcalino de Poços de Caldas 28

IV.3.3.2. Com os granitos e migmatitos 29

IV.3.4. Litologia 30

IV.3.5. Geologia Estrutural 31

IV.4. Rochas Sedimentares 32

IV.5. Maciço Alcalino de Poços de Caldas 33

IV.5.1. Forma e Dimensōes 33

IV.5.2. Correspondência Geomorfolögica 33

IV.5.3. Relações de Contato 33

iV.5.4. Litologia 33

IV.6. Estruturas Geolögicas 34

IV.6.1. Disposição dos corpos 34

IV.6.2. Distribuição das direçōes de foliações ou bandeamentos 35

IV.6.3. Falhas 35

IV.6.4. Fraturamentos 35 
V.1.1. Descrição Macroscōpica 37

V.1.2. Descrição Microscōpica 37

V.2. Granitos Porfiröides 39

V.2.1. Descrição Macroscópica 39

V.2.2. Descrição Microscōpica 40

V.3. Granitos Equigranulares 43

V.3.1. Descrição Macroscōpica 43

V.3.2. Descrição Microscōpica 43

V.4. Maciço Sienitico da Serra da Pedra Branca 46

V.4.7. Descrição Macroscópica 46

V.4.2. Descrição Microscōpica 46

V.4.3. Xenólitos que ocorrem no Maciço Sienitico 63

V.4.3.1. Descrição Macroscöpica 63

V.4.3.2. Descrição Microscópica 63

V.4.4. Diques pegmatiticos no maciço da Pedra Branca

V.4.4.1. Descrição Macroscōpica 65

V.4.4.2. Descrição Microscōpica 67

$\begin{array}{ll}V .5 \text {. Rochas Sedimentares } & 68\end{array}$

V.5.1. Descrição Macroscōpica 68

V.5.2. Descrição Microscópica 68

V.6. Rochas do Maciço Alcalino de Poços de Caldas 69

V.6.1. Tinguaitos 69

V.6.1.1. Descrição Macroscōpica 69

V.5.1.2. Descrição Microscōpica 69

V.6.2. Nefelina Sienitos 70

V.6.2.7. Descrição Macroscōpica 70

V.6.2.2. Descrição Microscōpica 70

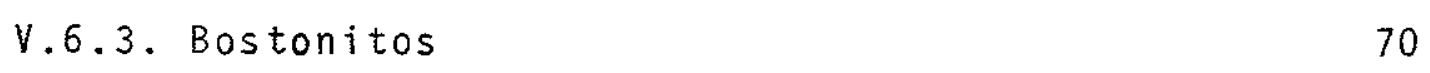

V.6.3.1. Descrição Macroscōpica 70

V.6.3.2. Descrição Microscópica 71 
VI. GEOCRONOLOGIA 72

VI. 1. Mëtodo K-Ar 73

VI.2. Método Rb/Sr 75

VII. DISCUSSAOO DOS RESULTADOS 80

VII.1. Evolução Geológica Local 80

VII.2. Os Sienitos do Maciço da Pedra Branca 81

VIII. AGRADECIMENTOS

IX. BIBLIOGRAFIA 85 
Figura 1 - Localização da ārea estudada.

Figura 2 - Esboço geotectōnico da parte Sul do Craton de São Francisco (seg. Ebert, 1956).

Figura 3 - Mapa geológico do Leste do Estado de São Paulo e Sul de Minas Gerais (seg. Ebert, 1968).

Figura 4 - Mapa geológico simplificado da Região Nordeste do Estado de São Paulo e Sul de Minas Gerais (seg. Fiori, Wernick e Betten court, 1978).

Figura 5 - Isōcrona de Referência dos Granitos

Figura 6 - Isōcrona de Referência dos Sienitos

Tabela 1 - Composição Modal dos Sienitos Saturados a Ins a turados.

Tabela 2 - Composição Modal dos Sienitos Saturados a Super Saturados.

Tabela 3 - Resultados das Determinações K-Ar.

Tabela 4 - Valores de Razão Inicial para Rochas da Area da Pedra Branca. 


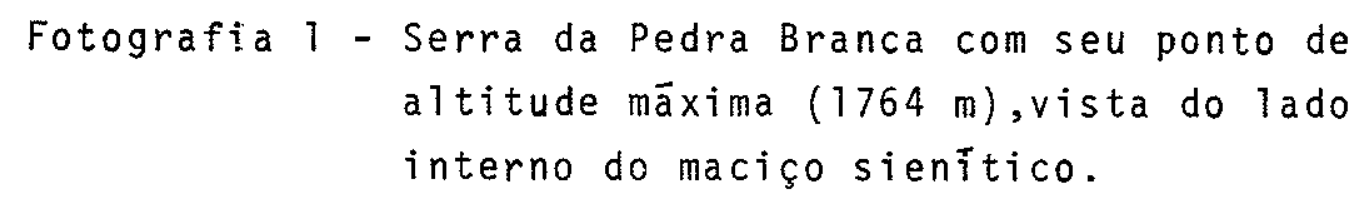

Fotografia 2 - No primeiro plano nota-se a pequena pla nicie aluvionar do Rio Jaguari- Mirim entre Santa Rita de Caldas e Ibitiurade Minas. No segundo plano as rochas graniticas. A fundo destacam-se os sieni tos da Serra da Pedra Branca.

Fotografia 3 - Região de contato entre os granitos e sienitos onde se nota a brusca mudança de relevo próximo ao afloramento 115. os sienitos se encontram à direita na foto (NE).

Fotografia 4 - Aspecto geral do sienito, em matacão partido mostrando estrutura fluidal e pequenos "xenōitos".

Microfotografia 1 - Granito porfirōide. Aspecto Geral da "matriz" dos granitos porfirói des mostrando substituição do mineral acessōrio hornblenda pela bioti ta. Nicóis $X$, aumento $25 x$.

Microfotografia 2 - Granito porfiróide. Detalhe da "matriz" dos granitos porfiróides mostrando plagioclásio subhedral em contato com microciina e biotita.Ni cóis $x$, aumento $32 x$. 
Microfotografia 3 - Aspecto geral do granito equigranular evidenciando o amplo predominio da microclina sobre os plagioclásios. Ni cóis $X$, aumento $10 x$.

Microfotografia 4 - Sienito fluidal com cristais alongados e tabulares de ortoclásio, com geminação Carlsbad. As fraturas são perpendi culares ao alongamento dos feldspatos. As partes mais claras dos piroxēnios in dicam inicio de sua substituição pela biotita. Nicóis $X$, aumento $10 x$.

Microfotografia 5 - Sienito mostrando estrutura fluidal na qual fica evidente que os planos de geminação dos felspatos não são retilíneos e as fraturas são perpendiculares a estes planos. Nicóis $x$, aumento $10 \mathrm{x}$.

Microfotografia 6 - Cristal de ortocläsio mostrando crescimento de "agulhas" e "pingos" de mate rial não identificável, alēm de opacos. Dentro do "pingo" há textura de exsolução. Notar plano de geminação não retiTíneo e fraturas perpendiculares ao pla no de geminação. Nicöis $x$, aumento 100x.

Microfotografia 7 - Diopsidio e hornblenda mostrando secções basais com linhas de clivagem bem desenvolvidas com o segundo substituindo o primeiro, evidenciando tambēm a disposição ortogonal entre os piroxēnios. Nicóis//, aumento $25 \mathrm{x}$.

Microfotografia 8 - Substituição direta de piroxênio por biotita, que tambēm substitui a hornblenda. Notar secção basal do piroxênio com linhas de clivagem bem desenvol vida. Nicóis//, aumento $25 x$. 
Microfotografia 9 - Substituição do piroxēnio por anfibō 1io. Observar pequeno cristal ovalado de zircão dentro da hornblenda.Ni cóis $/ /$, aumento $32 \mathrm{x}$.

Microfotografia 10 - Verdadeiro resto de piroxēnio den tro da hornblenda associada à magne tita. Nicóis//, aumento $32 x$.

Microfotografia 11 - Restos de piroxēnio (no caso aegiri na-augita) dentro da hornblenda associada à titanita e opacos.Nicois//, aumento $25 x$.

Microfotografia 12 - Substituição de piroxênio por hornblenda e deste por biotita. Nicöis//, aumento $10 \mathrm{x}$.

Microfotografia 13 - Contato de corrosão entre piroxênio e anfibölio (cor verde) sendo que ambos mostram inicio de substitui ção por biotita. Nicóis $x$, aumento $32 \times$.

Microfotografia 14 - Sienito na qual se observa que a biotita acompanha a estrutura fluida1. Nicóis $X$, aumento $25 x$.

Microfotografia 15 - Nefelina (no centro) associada à or toclāsio, apatita e aegirina-augita. Nicóis $X$, aumento $32 \mathrm{x}$.

Microfotografia 16 - Afloramento A-171 "Xenölito" do tipo "schileren" composto de plagiocläsio, biotita e espinēlio (grãos pequenos, extintos). Nicóis $x$, aumento $25 \mathrm{x}$.

Microfotografia 17 - "Xenōlito" composto quase que exclu 
$-i x-$

Sivamente por aegirina-augita.Nicóis

$X$, aumento $25 \mathrm{x}$.

Microfotografia 18 - Detalhe da microfotografia 14, mostrando textura adcumulática dos piro xênios. Nicóis $x$, aumento $32 x$.

\section{ANEXOS}

Mapa Geolögico da Area entre Caldas e Andradas-MG.

Mapa de Pontos da Area entre Caldas e Andradas-MG. 


\section{I - INTRODUCAO}

\section{I.1 - Justificativa do Tema}

$$
\text { I.1.1 - Histōrico }
$$

As informações mais recentes referentes aos contatos do Maciço Alcalino de Poços de Caldas, devem-se aos traba Thos de Ellert (1959), Ellert, Bjornberg e Coutinho (1959) e Cou tinho (1959).

Nestes trabalhos estão brevemente mencionadas duas äreas de metamorfismo de contato, caracterizadas por forte dessilicificação e adição de ālcalis ( $N a$ e $K$ ), conhecido sob o nome de "fenitização" (Brogger, 1921 e Eckermann, 1948). Destas āreas, uma estā situada a Oeste-Noroeste, na região de Cascata São Roque da Fartura e a outra a Sudeste, na região compreendida entre as cidades de Caldas e Andradas.

Em 1973, sob a orientação do Prof.Dr. Heinz Ebert, iniciamos o estudo deste interessante assunto, com o auxilio do CNPq, sob a forma de uma Bolsa de Iniciação Cientifica (proc. 386/73), concedida em março de 1973 até abri1 de 1975.

Neste periodo fez-se o trabalho geolögico chegan do-se, com os dados de campo e microscópicos, às seguintes conclusões: na ārea de Cascata-são Roque da Fartura as relações de campo evidenciaram realmente uma faixa fenitizada, porém bastan te irregular quanto à sua distribuição regional, portanto, discordante das limitações originärias de Ellert et al. (1959), com seus contatos entre gnaisses e fenitos, perpendiculares ao conta to do maciço alcalino e do contato proposto por H.Ebert (comunição verbal) com forma lenticular continua. Na ärea entre Caldas e Andradas este estudo foi levado mais a diante com a apresentação do mapa geológico preliminar (Winters, 1975). Nesta àrea,atē então, jā se tinha provado que se tratavam de sienitos prē-Cambrianos e não de fenitos. Os feldspatos alcalinos são de origem primāria, não havendo a substituição do plagioclāsio e quartzo por feldspato potássico, de biotita por hornblenda e da hornblen 
da por aegirina, substituições estas que se dariam quando da intrusão do maciço alcalino. Para esta negativa serviram de base as relações de campo e microscopia das läminas petrogräficas de amostras coletadas na região.

De 1975 em diante, esses estudos foram completados, novamente, com o auxilio do CNPq, sob a forma de Bolsa de Pós-Graduação (proc. 14.687/74), no período de março a abril de 1975-1976, com mëtodos que serão descritos em item especifico, complementando assim a Dissertação de Mestrado que ora apresenta mos.

\section{I.1.2 - Importância}

Achou-se interessante o estudo das rochas sieniticas, especificamente, pela falta de estudos mais detalhados no Brasil, visando esclarecer os fenōnemos associados a estas rochas. Fator de importāncia na descrição dos sienitos ē que pouca coisa existe na literatura nacional, em relação a rochas sienitticas prē-Cambrianas, sendo que os ünicos atē agora petrograficamente descritos são os de Piqueri (Picada, 1966) e o de São Gonçalo (Vandoros e Coutinho, 1966). Alguns outros são apenas mencionados (Pedreira, 1978, Itaūba, BA) ou descritos em publica ções ou relatōrios inacessiveis. Seria interessante na explicação da gênese dos sienitos ressaltar que, embora atē agora cons derados fenitos (produtos de metassomatose quando da intrusãodas alcalinas de Poços de Caldas) neste trabalho se provará tratar -se de sienitos pré-Cambrianos, não relacionados às alcalinas.ou tros corpos do mesmo tipo de sienito já foram observados na mesma região. Uma das ocorréncias localiza-se a Nordeste do Maciço de Poços de Caldas, não ocorrendo nesta região o contato direto entre os dois tipos de rochas (Wernick 1977). A outra localiza-se nos arredores de Pinhal - SP (Ebert e Brochini, 1968; Wernick 1978b).

Observe-se a esta altura,que, Guimarães (1947)te ria sido o primeiro autor a identificar as rochas sieniticas objeto deste trabaiho. Faz ele uma listagem mineralógica sumāriade duas amostras que denominou shonkinito, uma proveniente de aflo- 
ramento junto ao hotel de Pocinhos do Rio Verde e outra do retiro de José Antonio Caetano, ao norte de Andradas. Dentro do contexto do trabalho "Origem das rochas alcalinas", Guimarães aparentemente interrelaciona geneticamente os sienitos de Pedra Branca com as alcalinas do Planalto de Poços de Caldas.

\section{I.2 - Caracterização da Area}

\section{I.2.1 - Localização}

A ārea mapeada, com um total de cerca $440 \mathrm{~km}^{2}, 10$ caliza-se no extremo Sul do Estado de Minas Gerais e é limitada aproximadamente pelos paralelos $23^{\circ} 55^{\prime}$ e $22^{\circ} 05^{\prime}$ sul e pelos meridianos $46^{\circ} 35^{\prime}$ e $46^{\circ} 20^{\prime}$ (Figura 1). Compreende parte das FoThas de Caldas SF-23-V-D-IV-3, Pinhal SF-23-Y-A-III-2 e Santa Ri ta de Caldas SF-23-Y-B-I-1 editadas pelo IBGE na escala de $1: 50.000$.

Situam-se na ārea, as cidades de Andradas, Ibitiura de Minas, Santa Rita de Caldas e Caldas. As principais cidades localizadas nas imediações são: Pouso Alegre a sudeste, Ou ro Fino a Sul e Poços de Caldas a Noroeste.

\section{I.2.2 - Vias de Acesso}

0 acesso à região é relativamente fācil, podendo ser feito atravēs da rodovia MG-62 que liga as cidades de Poços de Caldas e Pouso Alegre. Contudo, especificamente na ārea mapeada, as condições de acesso são bastante dificeis, sendo os únicos trechos com träfego permanente; a rodovia acima menciona da e a estrada não pavimentada que liga Santa Rita de Caldas a Andradas. Ainda, devido às condições topogrāficas adversas,o trä fego é periódico nas demais estradas sendo que muitas vezes encontram-se intransitáveis e em total estado de abandono.

\section{I.2.3 - Clima}

o clima da região é caracterizado pela existência 
Figura - I

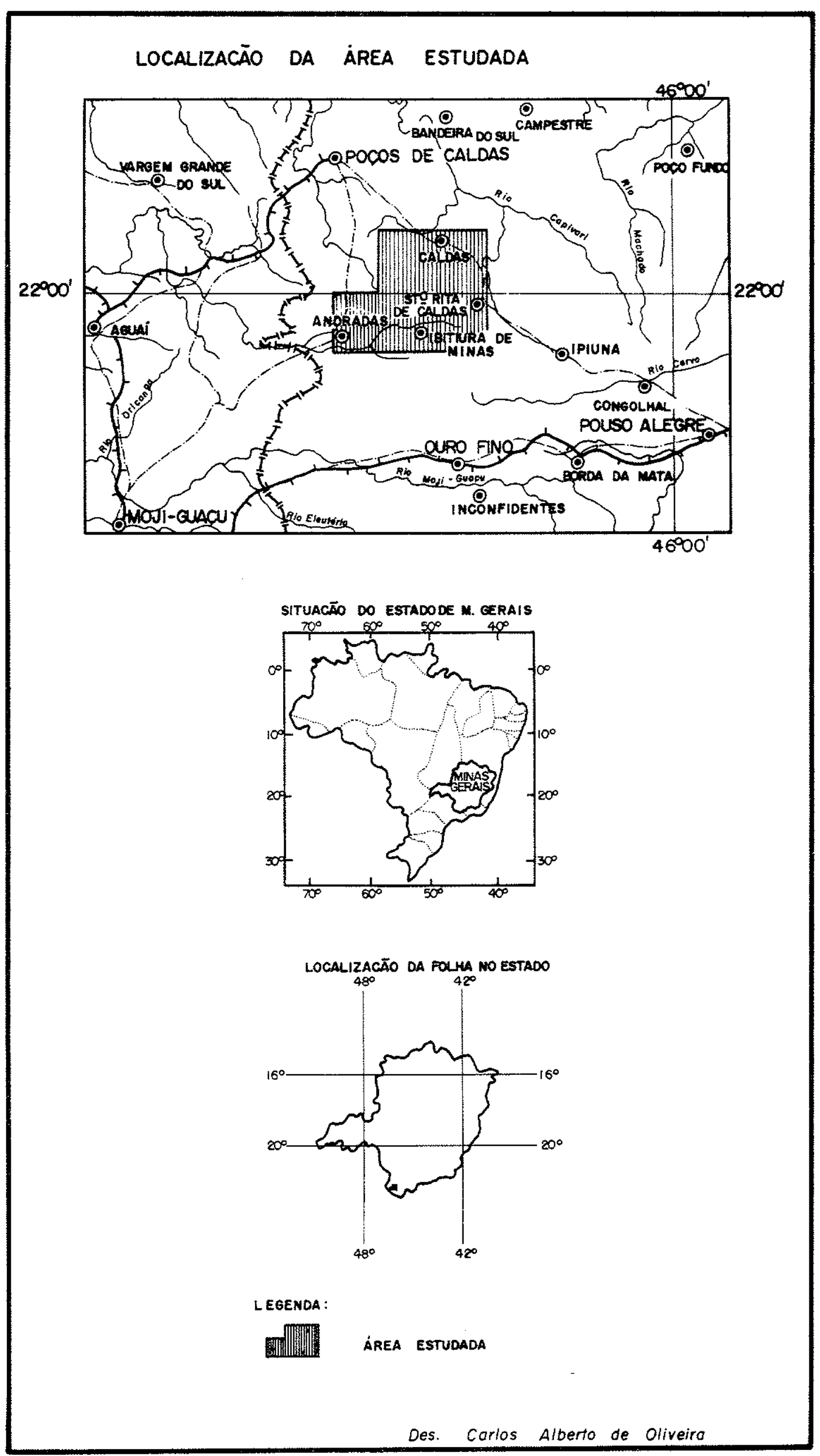


de uma estação seca de inverno, com duração mëdia de 1 a 2 meses. A temperatura é bastante variāvel em função das elevadas altitudes da ārea: a média do mēs mais frio situa-se entre 15 a $20^{\circ} \mathrm{C}$, nas cidades e ficando abaixo de $15^{\circ} \mathrm{C}$ na zona serrana. Na classi ficação de Koeppen é um clima tipo Cwb, e na classificação do IBGE, um clima Tropical sub-seco e sub-quente com algumas zonas de Tropical brando e sub-seco (Soares, 1976).

\section{$1.2 .4-\underline{\text { Vegetação }}$}

0 conjunto vegetal da ärea é formada por campos rüsticos constituídos por Gramineas (predominando a chamada "bar ba de bode", Aristida pallens), cobrindo as encostas e seus topos arredondados.

A vegetação arbōrea e arbustiva apresenta-se dis seminada em pequenas manchas de arvoredo nas cabeceiras dos elementos de drenagem ou estendendo-se em faixas de largura variāvel e descontinuas ao longo dos cursos (matas ciliares). Esta vegetação pode ser englobada à mata latifoliada-tropical (Christofoletti, 1970).

Os pinheiros (Araucāria augustifolia) são encontrados em capões ou isolados nas matas, nas partes inferiores das vertentes e vārzeas, sempre fugindo das partes mais altas, dominada pelos campos.

\section{I.2.5. Economia}

As atividades economicas principais,que utilizam a mão de obra local, resumem-se à pecuāria, ao plantio da uva,da batata e do aproveitamento, em termos de economia de subsistên cia, das pequenas planicies aluviais onde haja concentrações humanas.

\section{I.3 - Metodologia}

As atividades básicas empregadas com as quais ob 


\section{A - Trabalhos de Campo}

0 mapeamento foi feito, após uma fotointerpretação preliminar, na escala de 1:50.000, no perĩodo de 1974-1976, na qual as bases utilizadas, foram as folhas topogräficas de Cal das, Santa Rita de Caldas e Pinhal, editadas pelo Departamento de Cartografia do Instituto Brasileiro de Geografia e Estatistica, IBGE, na mesma escala do mapa geológico.

Para a confecção do mapa geolögico foram feitos caminhamentos pelas estradas, caminhos e trilhas que recortam a ārea com o objetivo de se alcançar afloramentos, contatos, feições estruturais e a partir dos mesmos obter-se informações mine ralōgicas, petrogräficas e estruturais.

Durante a execução do trabalho de campo, realizou-se a coleta de amostra julgadas necessärias e representati vas, tanto para uniformização da nomenclatura, quanto para poste rior descrição, anālise microscópica e geocronológica. Nesta ca panha foram descritos e inventariados cerca de 270 afloramentos com coleta de aproximadamente 350 amostras, nas quais foram determinadas macroscopicamente as estruturas e texturas apresentadas pelas rochas, tanto em termos de afloramento como em amostras de mão. Nesta etapa os minerais principais foram identifica dos macroscopicamente o que possibilitou a nominação preliminar das rochas.

\section{B - Trabalhos de Laboratōrio}

Os trabalhos de laboratörio foram executados nas seguintes etapas:

\section{1 - Determinações Microscöpicas}

Foram confeccionadas, a partir das rochas coleta das no campo, 183 seç̧ões delgadas para estudos microscōpicos vị 
sando a caracterização dos diversos tipos litológicos.

$$
\text { Estes estudos constaram de três estāgios: }
$$

a - Determinação qualitativa

0 estudo qualitativo foi feito atraves de micros cōpio de polarização da Leitz-SN-LUX. Neste instrumento procurou -se identificar os diferentes minerais constituintes da rocha atravēs das seguintes propriedades: clivagem, fratura, relevo, in dice de refração em relação ao Bālsamo de Canadā, ãngulo de extinção, birrefringência, carāter ótico e sinal ótico. Esta identificação é acompanhada do estudo da textura e estrutura da rocha como decorrência das relações de fäbrica entre os cristais. pōs a determinação das propriedades, dā-se o nome definitivo à rocha.

\section{b - Determinação quantitativa}

A determinação quantitativa ("Modus"), visou a composição modal das rochas. 0 método "Point Couter" utilizado, consiste na contagem dos minerais constituintes da rocha atravēs de uma malha prē estabelecida de acordo com a sua granulação, no caso predominantemente de $0,5 \times 0,5 \mathrm{~mm}$, graduada no "Chariot" adaptāvel à platina do microscōpio de polarização. Feita a contagem geral dos minerais na secção delgada, calculou-se a porcenta gem equivalente a cada mineral.

Este estudo foi feito somente em rochas sieniticas, sem vestigios de decomposição e com certeza "in situ", num total de 39 amostras.

c - Estudos atravēs da Platina de Federoff

Estes estudos foram executados em cristais de feldspatos potāssicos, com o objetivo de se determinar não sō a triclinicidade como tambēm as leis de geminação dos mesmos. Este mëtodo consiste na determinação da posição dos vetores princi pais das indicatrizes óticas de cada indivĩduo, em relação à mor 
fologia do cristal.

As medidas são feitas em coordenadas polares $\left(A_{1}\right.$ = azimute; $A_{2}=$ inclinação; $A_{4}=$ rotação), transferidas posteriormente para uma projeção estereogräfica em papel transparente, em orientação bem definida, seja cristalogräfica ou oticamente.

Atravēs da rotação $A_{j}$, coloca-se o cristal em extinção a seguir inclina-se $A_{2}$ atē se poder fixar, pela extin ção total, um dos planos da indicatriz do cristal.

Caso este plano seja o que contēm os eixos ópticos, gira-se o cristal para a posição diagonal e determina - se seu carāter ótico com a ajuda, geralmente, da placa de gibsita. Por rotação de $A_{4}$, determina-se a posição de um ou ambos eixos óticos. Isto é feito em todos os individuos parciais de uma macla ou de um grupo de maclas, se a largura das lamelas o permitem. Também todos os elementos morfolögicos (planos de clivagem ou geminação) são medidos em relação às coordenadas.

\section{2 - Determinações Radiométricas}

As anālises radiometricas foram realizadas no Centro de Pesquisas Geocronolögicas da Universidade de São Pau 10. As determinações foram efetuadas pelos mëtodos K-Ar em minerais separados e $\mathrm{Rb}-\mathrm{Sr}$ em rocha total.

A descrição das tēcnicas utilizadas no mëtodo $K$ Ar, são encontradas em Amaral et a 1. (1966). As anāiises de Ar foram obtidas por diluição isotōpica em espectrōmetro de massa tipo Reynolds, adicionando-se aliquotas de $\mathrm{Ar}^{38}$ puro, retiradas de um reservatório. O teor de potássio foi analisado atravēs de fotometria de chama, com padrão interno de lîtio. As constantes empregadas nos cátculos foram:

$$
\begin{aligned}
& \lambda_{\text {tot }}=0,530 \times 10^{-9} \mathrm{ano}^{-1} \\
& \lambda_{\varepsilon}=0,585 \times 10^{-9} \mathrm{ano}^{-1} \\
& \% \text { atom. de } \mathrm{K}^{40} \text { em } \mathrm{K}^{\text {total }}=0,0119
\end{aligned}
$$


Nas determinações $R b-S r$ foram aplicadas as tēcnicas utilizadas por Torquato (1974). As anālises quantitativas de $\mathrm{Rb}^{\text {tot }}$ e $\mathrm{sr} \mathrm{t}^{\text {tot }}$, foram obtidas por fluorescência de raios $X$. As com posições isotópicas foram obtidas em espectrômetro de massa da marca Varian - Mat, tipo TH 5. As constantes empregadas nos cālcu los foram:

$$
\begin{gathered}
\lambda \mathrm{Rb}^{87}=1,47 \times 10^{-11} \text { anos }^{-1} \\
\mathrm{Rb} b^{85} / \mathrm{Rb}^{87}=2,59 \\
\mathrm{Sr} 86 / \mathrm{Sr}
\end{gathered}
$$

\section{C - Trabalhos Finais de Escritōrio}

Terminadas as etapas acima descritas e a interpre tação de todos os dados, procedeu-se a fotointerpretação final de acordo com a sistemática apresentada por Soares e Fiori (1976)que permitiu traçar as principais feições estruturais e tectônicas,execução dos desenhos, organização das tabelas, gräficos e fotogra fias, bem como a redação do presente trabalho. 


\section{II - GEOLOGIA REGIONAL}

A caracterização geológica regional da ärea teve inicio com os trabalhos pioneiros realizados por Ebert, a partir da década de 50 , nas quais identificou unidades geotectónicas no minadas Paraibides e Araxaides. Estas unidades geológicas tem di reções preferenciai.s NE-SW e NW-SE respectivamente e bifurcam-se aproximadamente a Nordeste do Estado de São Paulo e Sudoeste do Estado de Minas Gerais nas regiões de Poços de Caldas, Ouro Fino, Pouso Alegre, Amparo, etc..Ambos os ramos da bifurcação exibiriam zoneamento com a ocorrência de 3 faixas distintas: uma central, que corresponderia aos internideos, representadas estra tigraficamente pelos Grupos Paraiba e Juiz de Fora; uma faixa intermediāria que corresponderia aos externídeos compreendendoes tratigraficamente os Grupos Andrelândia (Paraibides, MG), Itapira (Paraibides, SP) e Varginha (Araxaides, MG) além dos Micaxistos Paraibuna, na Serra do Mar; e uma faixa externa, caracteriza da por dobramentos e falhamentos suaves incluindo o Grupo São João Del Rei. Delimitada pelos dois ramos ocorre uma área triangular, designado de Maciço de Guaxupé (Almeida et a1, 1976). As figs. 2 e 3 esboçam as unidades geotectônicas mencionadas.

No decorrer de seus trabalhos, Ebert realizou su cessivas adaptações no modelo inicial, como consequência das variações da ārea de ocorrēncia e da extensão das diversas unida des estratigráficas continuamente criadas, redefinidas ou abando nadas, de acordo com o desenvolvimento dos mapeamentos e disponi bilidade de novos dados.

Coube ainda a Ebert $(1968,1971,1974)$ correlá cionar as unidades criadas e estudadas em Minas Gerais com as posteriormente caracterizadas no Estado de São Paulo. Assim correlacionou tentativamente o Grupo Barbacena com o Grupo Amparo, os Grupos São João Del Rei e Andrelândia com o grupo Itapira e interpretou a Formação Eleutērio como sendo correlata ao Grupo Itajai. A fig.3 exibe a distribuição dos grupos criados na ārea bem como suas relações gerais.

Nos ü timos anos tem surgido um grande nümeros de 
Figura - 2

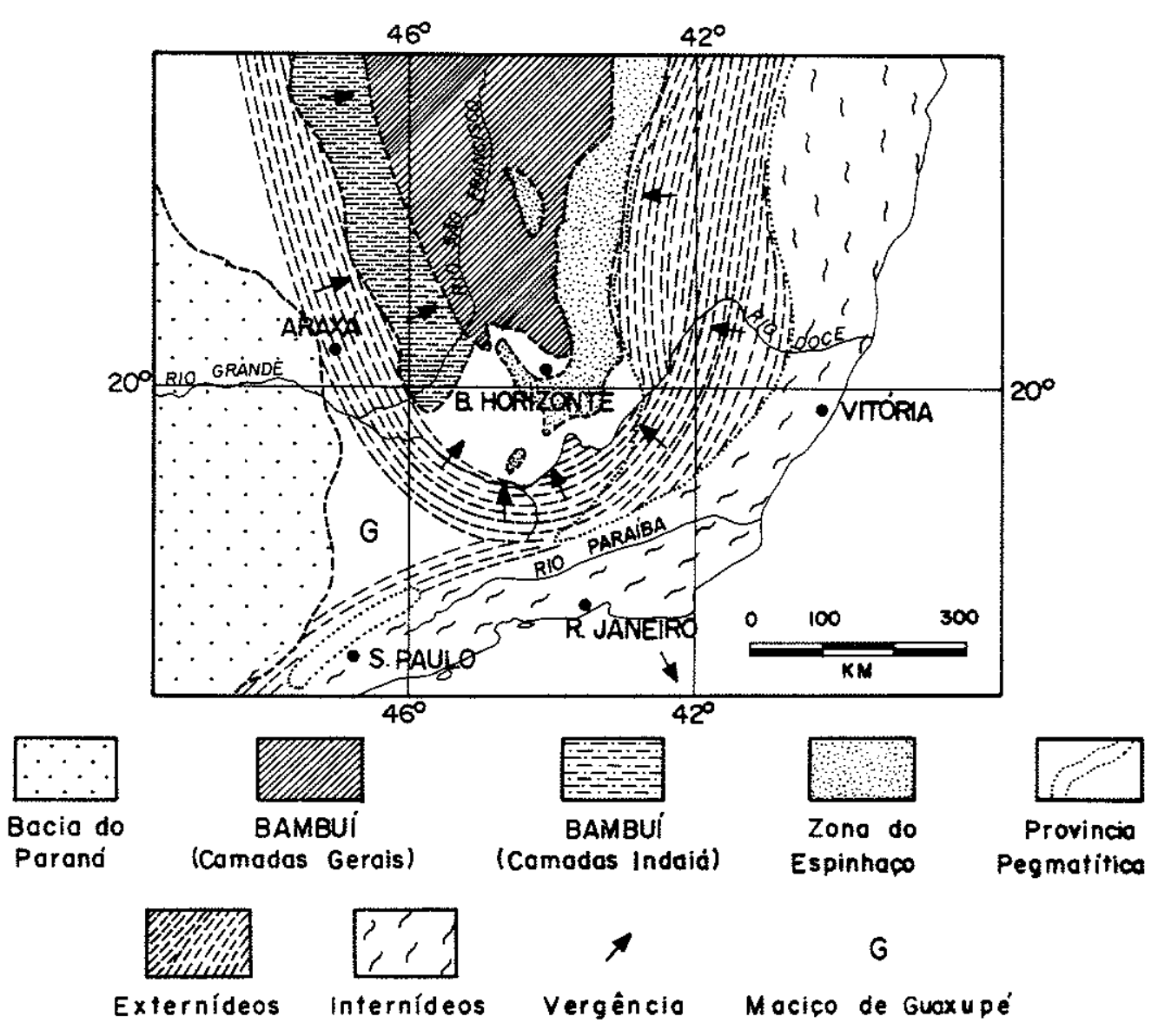

Esboço geotectonico do parte Sul do Graton de Sāo Francisco (seg. Ebert, 1956) 


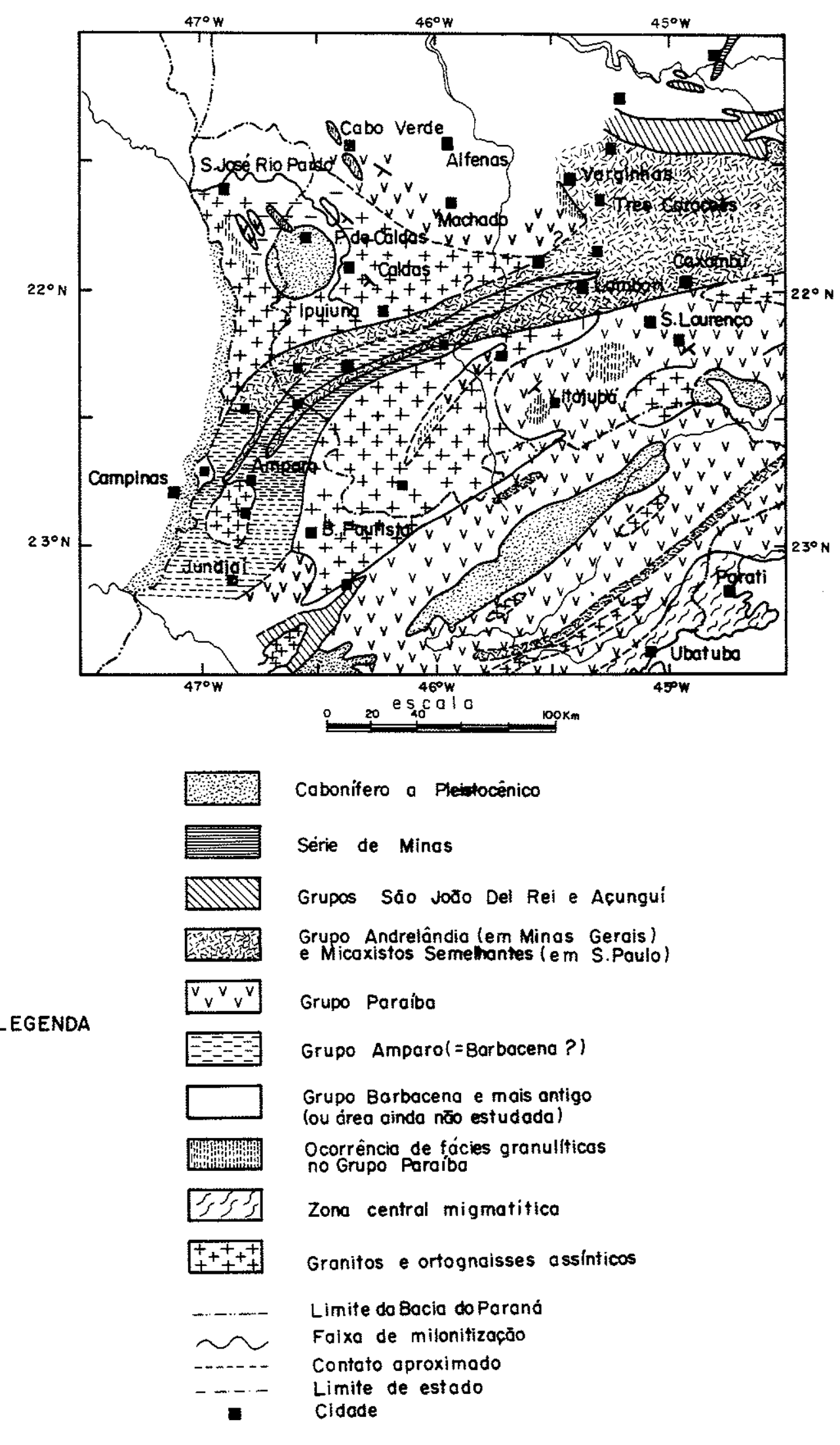

Mopo geológico do Leste do Estodo de Sōo Poulo e Sul de Minas Gerais (seg. Ebert, 1.968) 
dados geológicos, petrogrāficos, estruturais e geocronológicos re ferentes à ärea cristalina do Nordeste do Estado de São Paulo e Sul do Estado de Minas Gerais, atravēs de trabalhos de diversos autores, principalmente por parte de Fiori (1979), Wernick et a1. (1979), Artur et a1. (1979), Wernick e Fiori (1979), e Fiori et a 1. (1980). Destes trabalhos resulta o reconhecimento das seguintes unidades estratigräficas representadas, esquematicamen te, na figura 4 .

\section{A - Complexo de Silvianöpolis}

o Complexo de Silvianópolis (Fiori, 1979), corresponde a uma ampla ärea constituĩda essencialmente por anatexi tos de tipo embrechitico, predominantemente cinzentos, de composição variāvel entre tonalitica e granodioritica a granitica. As rochas apresentam foliação proeminente quer pela disposição para lela de minerais estirados, quer pela alternāncia entre leitos quartzo-feldspáticos e leitos descontinuos enriquecidos em bioti ta e hornblenda. Localmente associam-se gnaisses porfiroblásti cos e anatexitos irregulares do tipo flebitico ou schlierem.Fiori (1979) demonstrou que os embrechitos são produtos de intensa transposição dos anatexitos flebiticos e "schlieren", sendo reconheciveis naqueles ainda, localmente, dobras intrafoliares dis ruptas e com āpices espessados. A textura dos migmatitos é predo minantemente granoblástica e a dos embrechitos granoblástica-cataclästica. Entretanto, em parte do Complexo, os embrechitos mos tram-se, em maior ou menor grau, recristalizados e mesmo remobilizados, indicando terem sido submetidos a fenómenos térmicos pós - deformacionais que chegaram a desencadear fenômenos anatécticos. Ao Complexo de Silvianópolis foi atribuída idade arqueana. Rochas semelhantes ocorrem como nücleos ou intercalações tectōnicas no Grupo Amparo e no Maciço Pinhal (Wernick, 1967, 1978a, b; Ebert, 1968; Choudhuri et a1., 1978; Artur et a1., 1979; Wernick e Penalva, 1980).

B - Grupo Amparo

0 Grupo Amparo, de idade Transamazōnica, è de acordo com Wernick (1967) e Ebert (1968) uma unidade metassedi - 


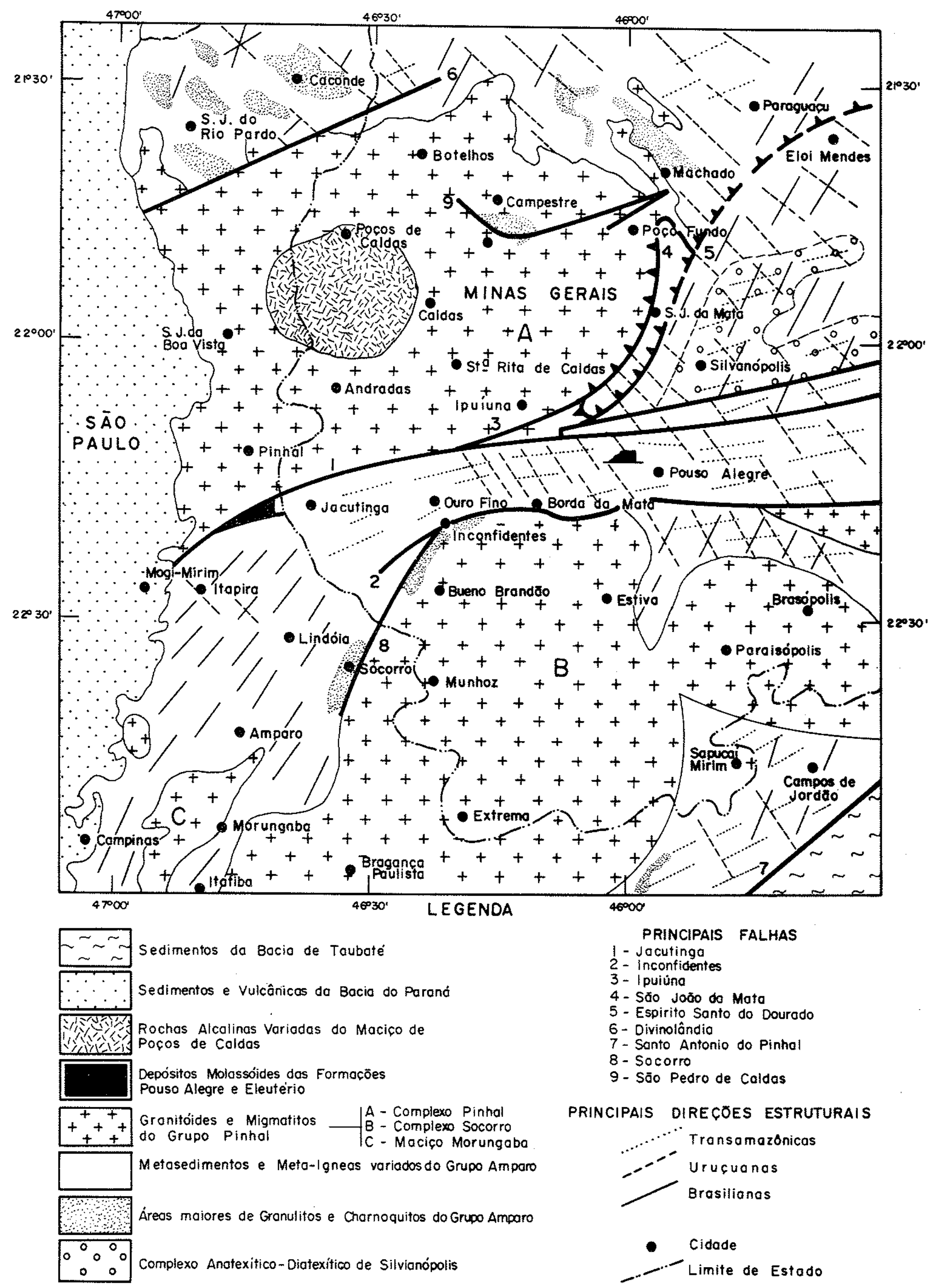

Mapa geologi simplificad do Regiño Nordeste do
Estado de Sôo Paulo Sul de Minos Gerais

Estado de SWori, Wernick B Bettencourt, 1978 .)
(seg. Fis 
mentar composta por biotita e/ou hornblenda gnaisses fitados e bandeados, de diversas naturezas, frequentemente anatexiticos com intercalações de anfibolitos, meta-ultrabasitos, gonditos, märmores dolomiticos, granulitos e rochas calcossilicatadas. (Fig.4) 0 referido Grupo ocorre no Bloco Jundiai, situado ao Norte dos faThamentos de Jundiuvira e Itu, assim como no Maciço Pinhal, localizado ao Norte do falhamento de Jacutinga (Penalva e Wernick, 1973a). Para Leste,sua ārea de exposição sofre um estreitamento lo cal passando a constituir, entre Socorro e ouro fino, uma faixa situada entre os complexos granitico-migmatiticos de socorro e Pinhal, em relação aos quais exibe contatos eminentemente tectóni cos, dados pelos falhamentos transcorrentes de jacutinga e Inconfidentes.

Fiori (1979) redefiniu o Grupo Amparo, retirando de sua litologia as rochas granuliticas, embrechiticas, gnaisses graniticos, certos gnaisses porfiroblästicos e alguns tipos de anatexitos, referindo-as ao embasamento desta unidade do protero zöico Inferior.

o padrão estrutural apresentado pelas rochas do Grupo Amparo è complexo, com evidencias de redobramento e transpo sição. O metamorfismo é da fácies anfibolito, chegando a provo car fenômenos de anatexia com a formação de metatexitos diversos e localmente diatexitos. Em muitos casos, especialmente no comple xo de Silvianópolis, dada a intima associação entre rochas do Grú po Amparo e as do seu embasamento, torna-se extremamente difici a distinção entre os anatexitos formados a partir dos metassedi mentos do Grupo Amparo e os resultantes da remobilização do seu substrato arqueano.

As rochas do Grupo Amparo ainda exibem sinais de polimetamorfismo, caracterizado pelo desenvolvimento de saussuritização dos plagioclásios, formação de clorita a partir de grana das e biotita, desenvolvimento de biotita em anfibólios, etc., indicando a superposição de condições metamōrficas mais brandas sobre paragêneses geradas sob condições mais intensas. Descrições mais pormenorizadas da litologia do Grupo Amparo são devidas a Franco e Coutinho (1957), Gomes et al. (1966), Wernick (1967, 1972a,b, 1977), Pires et a1. (1970), 01iveira e Alves (1974,1976), 
01 iveira (1973), 01 iveira e Hyppolito (1973), Wernick e Artur (1974), Wernick et a 1. (1976a), Soares (1976), Choudhuri et al. (1977), Choudhuri e Fiori (1978) e Fiori (1979).

O Grupo Itapira, interpretado por Ebert (1971) como de idade Brasiliana, seria representado por micaxistos, quartzitos, meta-arcōsios e metagrauvacas, geralmente de grau de metamorfismo mais baixo, granulação mais fina e com infiltra ções pegmatiticas restritas, não pode ser distinguido, de acordo com Wernick e Penalva (1973) e Artur (1980), do Grupo Ampa ro. Estes autores tambēm não reconheceram o complicado padrão estrutural postulado por Ebert, representado por uma sucessão de sinclinais e anticlinais especiais, os primeiros ocupados pe 10 Grupo Itapira e os segundos pelo Grupo Amparo. Consideram,em consequéncia, ambas as unidades equivalentes, variando apenas no aspecto faciolögico da sedimentação. Igualmente, os trabalhos desenvolvidos na região de Santa Rita de Caldas e Ipuiuna, no âmbito do convênio DNPM/FFCL de Rio Claro (Soares, 1976;coor denador), não permitiram constatar que as rochas referiveis por Ebert ao Grupo Itapira ou Andrelândia pertencessem a um ciclo orogênico mais novo que o gerador do Grupo Amparo.

\section{C - Grupo Pinhal}

Trata-se de uma unidade granito-migmatitica, re sultante da injeção granitica em rochas do Grupo Amparo, constituindo dois complexos: o de Pinhal e o de Socorro (Fig.4). 0 complexo Pinhal situa-se ao Norte da Falha Transcorrente de Jacutinga-Ipuiuna (Ebert, 1968; Wernick e Penalva, 1973; Penalva e Wernick, 1973b; Soares, 1976; Rodrigues, 1976). Este complexo acha-se encoberto a Oeste pelos sedimentos da Bacia do Para nä e para Leste o seu limite se estende às proximidades de São João da Mata (MG). A Norte estende-se alēm das cidades de BoteThos e São josé do Rio Pardo.

- Complexo de Socorro situa-se ao Sul da Falha Transcorrente de Inconfidentes (Soares, 1976; Wernick, 1977)des de as proximidades da cidade de Socorro (SP), atē a 0este da localidade de Brasópolis (MG). Para o Sul estende-se além da cí 
dade de Bragança Paulista, atē as proximidades de Sapucai Mirim e Campos de Jordão.

A estes complexos ē atribufda idade Brasiliana (Cordani e Bettencourt, 1967; Ebert e Brochini, 1968; 01iveira, 1973; Wernick et al., 1976c).

As rochas granitōides dos dois complexos são de natureza variāvel, incluindo termos equigranulares, finos a gros sos. As estruturas que predominam nestas rochas são porfirōides, isotrōpicas ou gnāissicas. A composição mineralógica varia entre termos graniticos a quartzo-dioriticos, incluindo alguns sien tos. Nas rochas equigranulares são comuns rochas com grandes cristais arredondados de quartzo indicando origem sub-plutónica. Nos termos porfiróides os megacristais normalmente são de microclina com coloração rosada, podendo alcançar värios centrímetros no seu comprimento, ostentando formatos retangulares, ovalados e irregulares. Estes megacristais estão inseridos numa massa hipau tomōrfica granular mēdia a grossa, leucocrätica a mesocrática,de composição granîtica a quartzo-dioritica. A composição mëdia glo bal predominante das rochas é adamelîtica. As intrusões são controladas por falhas e estruturas dobradas. Aos termos piutonicos e subplutônicos associam-se diques de granito pörfiro, pegmatito e quartzo, cujo alojamento é controlado por fraturas e falhas. As descrições das rochas graniticas da região são devidas a Wernick (1972b,c), Wernick et a]. (1976c) e Wernick e Penalva (1980).

Os migmatitos são, na sua maioria, de cor rosa e com estruturas, segundo a classificação de Mehnert (1968), acamada, agmatitica, "schollen", "schlieren", nebulitica, homofámica, dobrada e oftalmítica. A migmatização é acompanhada de processos metassomāticos mais ou menos intensos que afetam não sō os dife rentes tipos de migmatitos mas tambēm as intercalações de rochas do Grupo Amparo, isentas de injeções de material granitico.

A]ém dos trabalhos acima mencionados, descrições de algumas feições petrogräficas e mineralógicas do Grupo pinhal são devidas a Wernick (1972a), Wernick e Fernandes (1972), 01iveira (1973), Oliveira e Alves (1974), Wernick e Penalva (1974a, 1978) e Gomes (1976), bem como à elaboração de uma sintese, por 
Wernick e Penalva (1980).

D - Formações Eleutērio e Pouso Alegre

As Formações Eleutērio (Ebert, 1974) e Pouso Ale gre (Leonardos Jr. et.al. 1971) são sequências sedimentares de natureza anquimetamōrfica, constituídas essencialmente por areni tos arcosianos e arcósios, localmente conglomerāticos e silicifí cados. Associam-se meta-argilitos e meta-margas com clivagem ardosiana, brechas e conglomerados.

A Formação Eleutērio ocorre sob a forma de uma estreita faixa com direção NE-ENE/SW - WSW, medindo cerca de $11 \times 1 \mathrm{~km}$, iniciando-se nas imediações de Eleutērio e terminado nas proximidades de Jacutinga. Seus limites, na porção ocidental, são predominantemente tectōnicos, colocando-o em contato com o Bloco Pinhal, atravēs da falha de Jacutinga,e, ao Sul, em contato com as rochas do Grupo Amparo. A Formação Pouso Alegre a Noroeste da cidade homōnima, com espessura aproximada de $500 \mathrm{~m}$, acha-se embutida no Grupo Amparo atravēs de contatos tectōnicos. Em alguns lugares é observada nîtida discordāncia angular em relação ao embasamento cristalino circundante.

Wernick e Penalva (1974b) sugeriram a correlação entre elas e mostram sua ocorrência nas proximidades da falha de Jacutinga (Penalva e Wernick, (1973b). Ebert (1971, 1974) sugeriu que a Formação Eleutério seria equivalente ao Grupo Itajaī e outros depósitos molassóides ligados ao Ciclo Brasiliano. A idade Brasiliana é confirmada por dados geocronológicos da Forma ção Pouso Alegre (Hama e Cunha, 1977).

E - Maciço Alcalino de Poços de Caldas

No Cretáceo Superior em diversos pontos do pais houve magmatismo alcalino das quais, na região se destaca o Maci ço Alcalino de Poços de Caldas. Este maciço possui forma ovalada sendo constituído por termos plutōnicos, hipoabissais, efusivas e pirociästicas. As rochas predominantes são respectivamente foi aitos, tiguaitos e fonōitos. Nas imediações do maciço (e.g.arre 
dores de Aguas da Prata, Pocinhos do Rio Verde e nas encostas do Serrote do Maranhão ao Norte de Caldas) e no seu interior (e.g. na Cachoeira Véu de Noiva) ocorrem intercalações de sedimentos referiveis ou Grupo Tubarão. 0 mapeamento e a descrição petrogrā fica deste complexo, são devidas a trabalhos de Ellert (1959), Ellert et a1. (1959) e Ulbrich et al (1977) e trabalhos desenvol vidos pela CNEN e Nuclebrás (p.ex. in Garcia de 0liveira 1974). 


\section{GEOMORFOLOGIA}

A caracterização geomorfológica da ārea serā des crita de forma suscinta destacando dois tópicos: anāilise do rele vo e anālise da drenagem.

\section{III.l - Anälise do Relevo}

Analisando-se a topografia dos mapas topogräficos base utilizados no mapeamento, pode-se dividir a ārea, consi derando como variāvel apenas a altitude. Esta variāvel permite distinguir duas äreas com comportamento diferencial em termos re lacionados com a resistência à erosão: ārea serrana eārea de "mares de morros".

\section{III.1.1 - Area Serrana}

E a ārea sustentada pelas rochas sieniticas da Serra da Pedra Branca com cristais de feldspato potássico orientados por estrutura fluvial e baixo teor em minerais mäficos,que a torna altamente resistente à erosão. Esta área é extremamente rica em exposições de rochas frescas, queda de blocos e matacões. os solos são relativamente rasos e ricos em fragmentos de feldspato potássico. A Serra da Pedra Branca apresenta a altitude máxima da ārea (1764 m). (Fotografia 1).

A Serra da Pedra Branca compõem-se na sua maior parte, de uma serra alongada, onde os topos são bastante agudos, desníveis variando de 280 a $600 \mathrm{~m}$, com värias direções preferenciais, correspondendo a região externa do maciço sienitico próxí mo ao contato com as rochas graniticas encaixantes. Esta serra prōximo a Caldas tem direção WNW, rumo a sul passa gradualmente para NNE, NS e por fim NNW a aproximadamente na região entre Ibi tiura de Minas e Santa Rita de Caldas. A Noroeste de Ibitiura de Minas, esta serra perde altitude, recebendo outro nome (Serra da Forquilha), sustentada por rochas graniticas. Na continuação oeste das rochas graniticas, novamente ocorrem regioes bastante aci dentadas, com morros agudos, sendo constituídos pela serra do Roncador (1453 m) sustentado pelo pequeno corpo isolado de ro- 


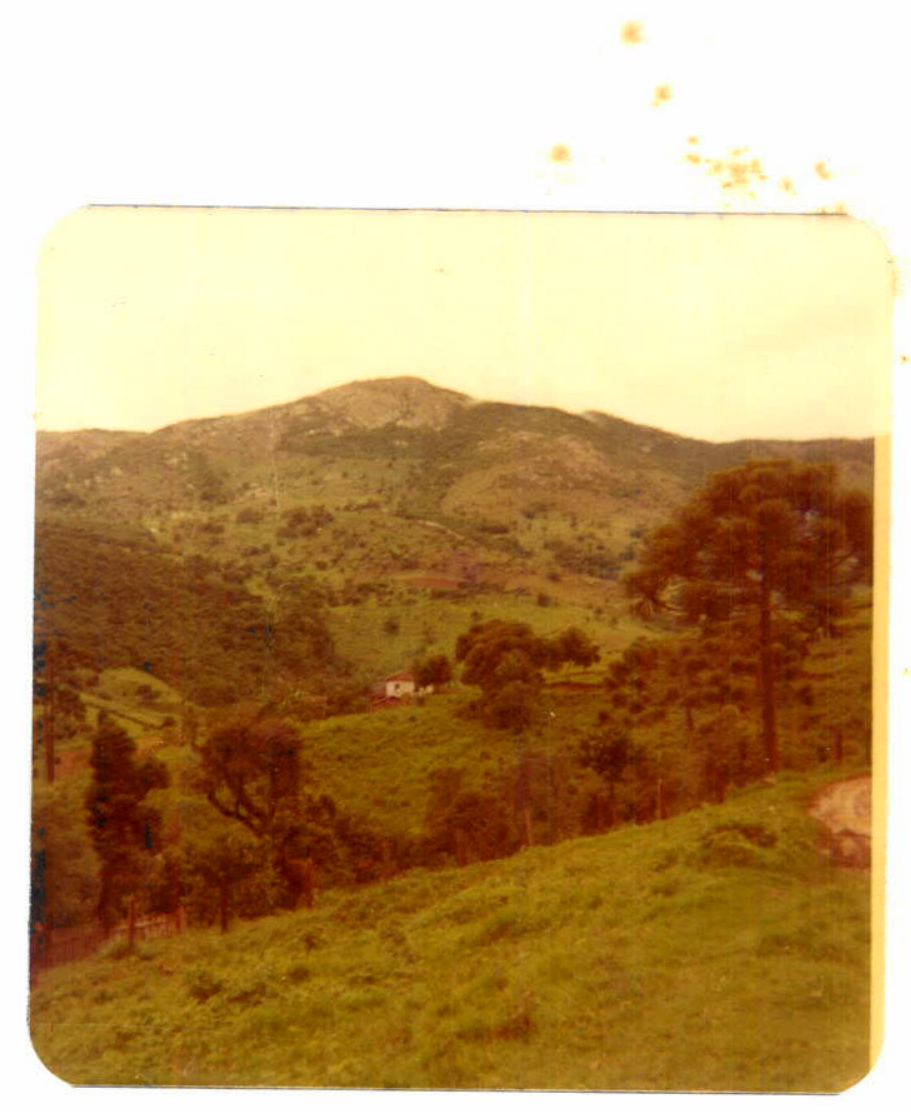

$-2 i-$

Fotografia 1 - Serra da Pedra Branca com seu ponto de altitude máxima $(1764 \mathrm{~m})$, vista do lado interno do maciço sienitico.

chas sieniticas e pela Serra do Caracol (1526 m) esculpida no es pigão anelar de rochas alcalinas que circunda o Maciço Alcalino de Poços de Caldas.

\section{III.1.2 - Area de "Mares de Morros"}

O termo "Mares de Morros" é empregado para relevos constituídos por morros arredondados, de mesma elevação, com encostas convexas e solos espessos (Pierre Deffontontaines, in Guerra - Dicionārio Geomorfológico, 1969). Esta é a caracteristí ca principal do restante da ārea mapeada, constituída por diversas litologias de composição granitica, e estruturas e texturas homogêneas, facilmente erodíveis. Os desníveis são em torno 100 $m$, os solos são dominantemente coluviais, espessos sendo os aflo ramentos rochosos, raros. Este fenómeno ocorre inclusive na região de contato entre a borda do maciço alcalino com a parte cen tral do maciço sienítico, onde a estrutura fluidal é pouco pronunciada. 
O maior desnivel ( $\pm 270 \mathrm{~m}$ ) é verificado nos granitos porfiróides associadas a granitos equigranulares (Serra do Rio Clarol na porção Noroeste de Santa Rita de Caldas. Na bacia do Rio Jaguari-Mirim a erosão deixou os vales com encostas ingre mes e o relevo mais rebaixado, com altitude média em torno de $950 \mathrm{~m}$, revelando o grande desnível da ārea (Serra da Pedra Bran$\mathrm{ca}, 1764 \mathrm{~m}$ ). (Fotografia 2)

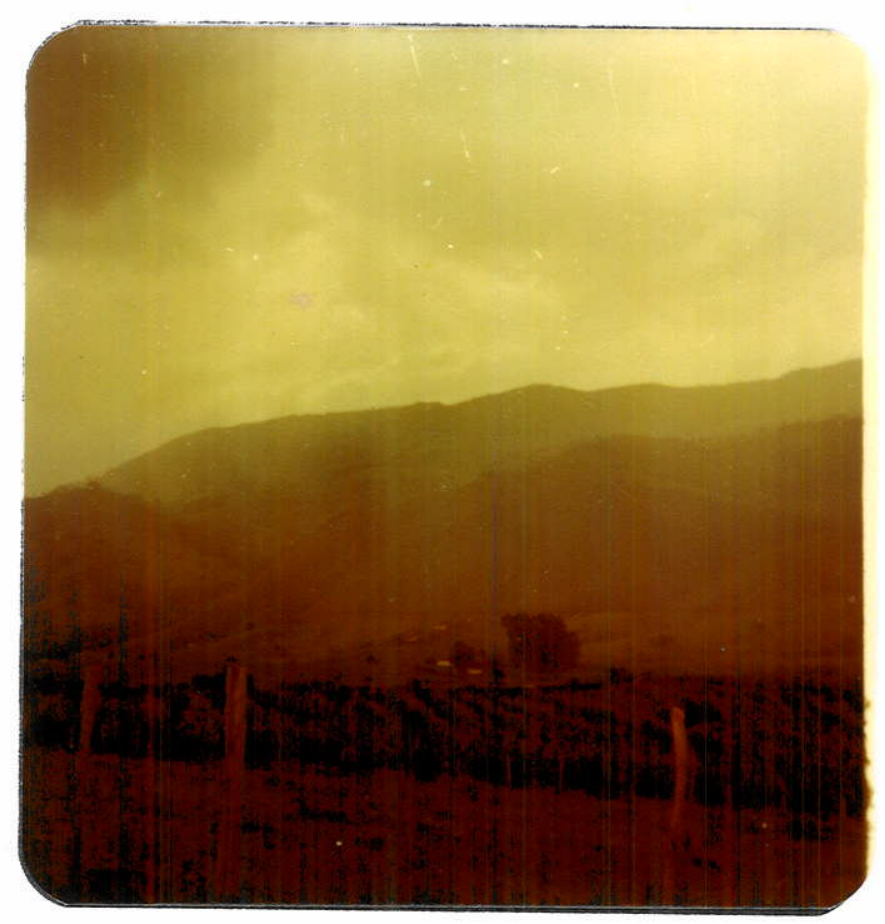

Fotografia 2 - No primeiro plano nota-se a pequena planicie aluvionar do Rio Jaguari-Mirim entre Santa Rita de Caldas e Ibitiura de Minas. No segundo plano as rochas graniticas. Ao fundo destacam-se os sienitos da Serra da Pedra Branca.

\section{III.2 - Anālise da Rede de Drenagem}

A ārea situa-se, de um modo geral, na margem Noroeste do Maciço Atrântico, ou "Provīncia do Planalto Atlāntico" (Almeida, 1964), incluindo parte do Planalto de Poços de Caldas. A parte mapeada é drenada pelas cabeceiras do Rio Jaguari-Mirim (Bacia do Rio Mogi-Guaçu) a Sudoeste, dos rios verde e claro (Ba cia do Rio Pardol, de Sul a Norte e Sudeste da ārea. Toda rede de drenagem pertence à grande Bacia do Rio Grande. O grande divi 
sor de āguas na região mapeada è a Serra da Pedra Branca.

O controle estrutural da drenagem na ärea, mostra uma ordem hierārquica bem definida: 10) contatos entre diferentes tipos litológicos e pequenas falhas; 20 ) foliações e juntas. Na primeira ordem, na ärea, estão os diversos rios controlados pelos contatos litológicos, no caso, Rio Verde e Ribeirão dos Bugres que são os mais extensos, enquanto os de pequenos falhamentos Nordeste são drenados pelos rios Jaguari-Mirim e Rio Claro. As de segun da ordem são drenagens controladas principalmente por juntas, de pequena extensão, cujas direções dominantes são Noroeste- Sudeste e Nordeste-Sudoeste.

De um modo geral ao analisar-se os cursos d'ägua da região, ou seja, os afluentes do Jaguari-Mirim, Rio Verde e Claro, observa-se que toda ärea apresenta uma densidade de drenagem uniforme não servindo essa caracterīstica para definição dos diferentes tipos litológicos.

Nas regiões mais acidentadas, os vales são em forma de $V$, indicando rocha dura, vales profundos, sem aluviões, retilineos ou curvos, correm quase na sua totalidade sobre rocha sã com saltos e corredeiras. Na região de "mares de morros" os vales são dominantemente de fundo chato, com pequenos aluviões, ladeados por colinas do tipo convexo e indicativo de solo espesso. 
IV - GEOLOGIA LOCAL

\section{IV.T - Migmatitos}

\section{IV.T.1 - Forma e Dimensões}

Os migmatitos circundam a parte externa do anel dos granitos equigranulares e porfiróides, sem forma e dimensöes definidas jā que sua ocorrência se estende para fora da àrea mapeada.

\section{IV.1.2 - Correspondēncia Geomorfolögica}

Corresponde à ārea de "mares de morros". Tratase da região que apresenta a topografia mais suave da área mape ada.

\section{IV.1.3 - Relações de Contato}

Acredita-se que as relações de contato com os granitos porfiróides seja de transição, pois à medida que se afasta do anel externo destes granitos a frequência relativa de material paleossomático é cada vez maior.

Como os granitos equigranulares e as rochas do Maciço Alcalino de Poços de Caldas o contato è intrusivo.

$$
\text { IV.T.4 - Litologia }
$$

Os migmatitos são rochas hïbridas, resultantes da injeção de material granītico em rochas prë-existentes. Nas rochas migmatiticas a parte nova, ou seja, a parte granitica $\bar{e}$ chamada de neossoma e a parte prë-existente de paleossoma. o ma 
material pré-existente ē constituĩdo por raros fragmentos de metassedimentos e principalmente por rochas anfiboliticas. A associação destas partes nos dão os mais diversos tipos de estrutu ras, sendo as mais comuns na ārea mapeada, as do tipo nebuliti co, "schlieren", "schollen" e oftalmitico. Estas rochas são. interpretadas como pertencentes ao maciço de Pinhal e acredita-se que a parte paleossomática faça parte do Grupo Amparo (Wernick, 1978) ou do Complexo Silvianōpolis (Fiori, 1979).

A composição da parte neossomātica ē adamelitica, na qual os minerais mais frequentes são microclina, oligoclásio (em proporções mais ou menos iguais), quartzo e biotita. Acessoriamente pode ocorrer: opacos, titanita, apatita e zircão.

A composição do paleossoma geralmente ē anfibolitica e consta essencialmente de andesina, hornblenda, e biotita. Como acessōrios encontram-se quartzo, opacos, titanita, epidoto, apatita e zircão.

\section{IV.2 - Granitos Porfirōides e Equigranulares}

Estas rochas serão descritas conjuntamente pois, na região Sul da ārea mapeada, em värias localidades situadas en tre Andradas, Ibitiura de Minas e Santa Rita de Caldas não hä condições de se fazer uma separação dos tipos graniticos referi dos, devido à interpenetração dos mesmos e à pröpria limitação da escala do mapa apresentado.

Tanto os granitos porfiróides como os equigranula res pertencem ao Maciço Pinhal.

\section{IV.2.I - Forma e Dimensões}

De um modo geral circundam o contato externo do Maciço da Pedra Branca, com formato de semi anel, com espessura më́dia de 2 a $3 \mathrm{~km}$. 
Pode ser individualizado, um corpo de granito por firōide a N-NE-E do maciço sientitico, truncado pela saliência de sienito a Sudeste da cidade de Caldas e dois corpos de granitos equigranulares, um a Noroeste de Santa Rita de Caldas e outro a Norte de Ibitiura de Minas. (mapa geológico anexo).

\title{
IV.2.2. - Correspondência Geomorfolögica
}

A ārea de ocorrēncia dos granitos porfirōides e equigranulares ē geomorfologicamente classificada como ārea de "mares de morros" onde o relevo é relativamente suave,apesar dos granitos porfiróides sustentaram regiões um pouco mais acidentados. Predominam morros arredondados, convexos, vales em forma de $U$ indicando fundo chato e com razoável cobertura de solos.

\section{IV.2.3 - Contatos}

Dos dois tipos de granitos, o equigranular é aparentemente mais jovem e corta os granitos porfiröides de maneira irregular e difusa, onde sinais de deformação ocorrem com certa frequência.

As relações de contato entre estes granitos e 0 Maciço da Pedra Branca são de natureza intrusiva demonstrando que o ültimo è mais jovem que os granitos.

Os contatos com os migmatitos, aparentemente, são de transição, pois, à medida que se afasta do corpo granitico,ob serva-se hibridização crescente das litologias graniticas devido à contaminação das mesmas por rochas de composição totalmente di ferente.

\section{IV.2.4 - Litologia}

\author{
IV.2.4.1 - Granitos Porfiröides
}


Esta unidade è constituida por microclina-adamelitos mesocrāticos portadores de quartzo, oligoclāsio e biotita. Apresentam megacristais de microclina com ate $5 \mathrm{~cm}$, com formas euhedrais a subhedrais, numa massa de granulação mëdia a grossa e coloração acinzentada. Os mega-cristais mostram certa orientação dispersos na matriz, normalmente maciça.

\section{IV.2.4.2 - Granitos Equigranulares}

São rochas de estrutura maciça, textura xenomörfica equigranular, granulação fina a média e ocasionalmente exibindo granulação grossa. Mineralogicamente são constituídos essencialmente por feldspato potássico, quartzo e biotita.

\section{IV.3 - O Maciço Sienitico da Pedra Branca}

\section{IV.3.1 - Forma e Dimensões}

0 maciço possui forma de um semi-círculo ( vide mapa geológico anexo) cujo vertice Norte fica nas proximidades de Pocinhos do Rio Verde, ( $3 \mathrm{~km}$ a Oeste da cidade de Caldas) e cujo diāmetro se estende $13 \mathrm{~km}$ para sudoeste. 0 semi- circulo possui um raio de $8 \mathrm{~km}$ na direção ESE, passa a Sul de caldas e mostra uma saliência para Nordeste perto desta cidade aflorando nas proximidades da rodovia Poços de Caldas - Pouso Alegre. A Sul desta saliência encontra-se, na Serra da Pedra Branca, o ponto mais alto do Planalto de Poços de Caldas, isto é, $1764 \mathrm{~m}$. $E$ um marco orogräfico visivel a grande distância (Fotografia 1).

Provavelmente, antes da intrusão do Maciço Alca lino de Poços de Caldas, o maciço sienitico teria forma horizon tal circular quase perfeita.

Uma outra ocorrência de forma irregular devido a falhamentos, e com provāvel forma original circular, situa-se 
a $4 \mathrm{~km}$ a Sudoeste da terminação do semi-cīrculo, no sentido Andra das. As dimensões aproximadas são de $3 \mathrm{~km}$ de comprimento por $1 \mathrm{~km}$ de largura.

\section{IV.3.2 - Correspondência Geomorfolögica}

Conforme jā descrito no item Geomorfologia a parte externa do semi-circulo, em contato com as rochas graniticas, assim como a ocorréncia isolada a Nordeste de Andradas, enquadra- se geomorfologicamente nas áreas serranas, isto ē, āreas de gran des desniveis topogräficos, morros agudos, pouca cobertura de so10, vales em forma de $V$ indicando rocha dura, vales profundos,sem aluviões, com ägua correndo sobre rocha sã com saltos e corredeiras.

A parte central do maciço sienitico, em contato com as rochas do Maciço Alcalino de Poços de Caldas, pode ser geo morfologicamente classificada como ärea de "mares de morros". Nes ta região a relevo é relativamente mais suave, com desníveis da ordem de $100 \mathrm{~m}$, constituído por morros arredondados, solos domi nantemente coluviais espessos. Os vales são em forma de $U$, fundo chato, com pequenos aluviões, encaixados por colinas do tipo convexo, indicativo de solo espesso.

\section{IV.3.3 - Contatos Externos do Maciço Sienítico}

\section{IV.3.3.1 - Com o Maciço Alcalino de Poços de Caldas}

Não cabe aqui discutir os possiveis mecanismos de intrusão do Maciço Alcalino de Poços de Caldas, ressaltando-se to davia que as relações de contato das rochas alcalinas com o Maciço da Pedra Branca são bruscas, discordantes, (a orientação de fluxo magmático dos sienitos se mostra, de um modo geral, perpendicular ao contato) e de natureza variada, como segue: 
a - contato direto, nitido e brusco entre os tinguaitos do Maciço de Poços de Caldas e os sienitos da Pedra Bran ca, a exemplo do afloramento 244.

b - contato direto, por meio de brecha alcalina (bostonitos), verificada no campo, situada entre os tinguaitos e os sienitos. Este tipo de contato é verificado nos afloramentos 258,257 e 241 (vi.de mapa de pontos).

Na maioria dos casos a interligação dos contatos, vistos no campo, foram feitas atravēs da interpretação aerofotogräfica, posteriormente confirmado no campo atraves da diferenciação litolögica nas proximidades do mesmo.

E interessante mencionar que na região de contato entre as duas grandes unidades o relevo não se impõe a favor de nenhuma delas, fato estranho, pois no restante do maciço alcalino, este se sobressai, atravēs dos diques anelares.

Pelos motivos acima expostos fica dificil afirmar que exista qualquer relação genëtica entre os dois maciços.

\section{IV.3.3.2 - Com os Granitos e Migmatitos}

O contato externo, circular, do Maciço da Pedra Branca com os granitos e migmatitos nunca foi observado no campo, devido à grande quantidade de blocos de sienitos e solo colu vial, proveniente da grande escarpa que os sienitos formam na região de contato. (Fotografia 3 ). Nas proximidades do contato os granitos mostram fenómenos de orientação paralela ao contato,com cataclase incipiente.

Por fotografias aēreas este contato ē nîtido devi do ao grande contraste topogräfico entre as duas unidades. Obser va-se, tambëm, no campo, uma orientação plano paralela dos feldś patos potássicos dos sienitos concordantes à forma circular do maciço alēm de diferenças fundamentais na composição mineralögica, estrutural e textural entre o sienito e as rochas graniticas. 
Isto leva a crer que o sienito é intrusivo nos granitos, intrusão esta, de penetração forçada, ou ainda, penetração de uma massa jă semi cristalizada, implicando em forte orientação mine raiógica destas rochas na sua parte externa.

Estas evidēncias afastam mais uma vez a hipōtese de fenitização que, pressupõe a existência de contatos transicionais e ausencia de alteração da estrutura e textura das rochas envolvidas no processo.

\section{IV.3.4. Litologia}

De um modo geral, trata-se de rochas que apre sentam estrutura fluidal mais ou menos desenvolvida, textura hi pidiomörfica inequígranular, granulação mëdia a grossa e cores rosa acinzentadas. A composição mineralögica destas rochas $\bar{e}$ bastante variada, mas globalmente podemos definir os seguintes minerais essenciais: ortoclásio, hornblenda, diopsídio ou aegirina-augita e biotita. Acessoriamente ocorrem värios minerais como apatita, quartzo, oligoclásio intercrescido ou não com quartzo (mirmequita), albita intercrescida no ortociásio (micro pertita), titanita, zircão, clorita, opacos e nefelina, esta,so mente no afloramento $115 b$ (vide mapa de pontos).

Restitos relativamente raros, alongados, de dimensões variāveis nunca superiores a $20 \mathrm{~cm}$, podem ainda ocorrer neste corpo. As extremidades são arredondadas, os contatos são muitas vezes difusos e mineralogicamente predominam minerais mä ficos.

Foram verificados ainda; um dique de tiguaito na ärea central do maciço, vārios veios de quartzo maciço que localmente chegam a atingir $2 \mathrm{~m}$ de espessura e ainda diques de material pegmatitico de espessura decimétrica com composição granitica, provavelmente associados à fase final volätil do maciço sienítico. 


\section{IV.3.5 - Geologia Estrutural}

As rochas do Maciço Sienitico da Pedra Branca ostentam forte orientação plano paralela, muito bem desenvolvida, principalmente por parte dos feldspatos potássicos de aspecto tabular segundo (010). Os minerais prismāticos (piroxēnios e anfibó lios) e placöides (micas) tambēm são orientados, porēm, de maneira não tão rigorosa. Esta orientação ē concordante com a forma semi circular externa do maciço sienitico, isto é, paralela ao contato. E na região do contato, ou seja a zona externa do maciço que este fenömeno se manifesta com maior intensidade.

Este processo de orientação plano paralela sucede - se sob a forma de fluxo laminar (C1oos, 1923), quando uma massa rochosa escoa-se no estado semi-sölido, com as particulas individuais deslizando entre si, em virtude das elevadas condições de pressão e temperatura reinantes no interior da crosta.

As lāminas de fluxo tendem a paralelizar os conta tos das encaixantes rỉgidas ou menos plásticas. Este fato não pode ser observado no campo pois a região de contato sempre encon tra-se encoberta por material coluvial, devido a grande diferença topogräfica que existe entre o sienito e suas encaixantes graniti cas (fotografias 2 e 3 ). A velocidade diferencial das vārias lāmi nas de fluxo, originando a estrutura planar, serā muito maior ná região externa que no interior do corpo rochoso, normalmente mais plástico (Loczy e Ladeira, 1976). Isto pode ser perfeitamente cor roborado jā que na zona interna do maciço (onde se situa o contato com as rochas do Maciço Alcalino de Poços de Caldas), esta orientação não se acha tão bem desenvolvida, assumindo aqui direções caōticas.

Segundo Loczy e Ladeira (1976), o termo estrutura planar de fluxo é praticamente sinōnimo de foliação primária, porēm ē mais abrangente por se referir à orientação planar preferen cial não só de minerais platiformes mas tambēm inclusões, comó as ocorrente nos sienitos da Pedra Branca, sob a forma de "schlie ren" de formas irregulares e segregações normalmente de formato ovalado. 
A principal feição estrutural do maciço sienitico no estado sōlido é o desenvolvimento de juntas transversais, is to $\vec{e}$, perpendiculares à estrutura circular configurada pela estrutura planar de fluxo. Este fenōmeno é observado tanto no campo como em secções delgadas.

\section{4 - Rochas Sedimentares}

0correm em äreas restritas nas imediações do Grande Hotel em Pocinhos do Rio Verde. Trata-se de corpo de are nito constituido na base por um arenito fino, medianamente fri vel, sobreposto por um siltito roxo quebradiço de pequena espes sura, o qual por sua vez ē recoberto por um arenito fino e duro. As espessuras das diferentes litologias que compõem este corpo são desconhecidas. Próximos a esta região foram mapeadas mais duas ocorréncias: uma no bairro de Campinas e outra nas en costas do Serrote do Maranhão. A primeira ocorréncia assenta-se sobre rochas migmatiticas e a segunda sobre rochas alcalinas (Wernick, 1975).

0 arenito geralmente é endurecido pelo metamor fismo tērmico de contato quando da intrusão. Esta intrusão deslocou o corpo de arenito de sua posição original, possivelmente horizontal a sub-horizontal, para direções diversas, mas dominantemente paralelo ao contato externo do Maciço Alcalino de Poços de Caldas, com mergulhos variando de $25^{\circ}$ a $45^{\circ}$ para o cen tro do maciço.

O corpo é essencialmente arenītico, constituĩdo de grãos de quartzo, apresentando granulação fina.

Hipoteticamente atribui-se a estes sedimentos $i$ dade permocarbonifera, em analogia a rocha semelhantes mapeadas por Ebert (1972) ao Tongo da Rodovia Pinhal-São João da Boa Vis ta. 


\section{5 - Maciço Alcalino de Pocos de Caldas}

\section{IV.5.1 - Forma e Dimensões}

Na sua totalidade o Maciço Alcalino de Poços de Caldas perfaz uma ärea aproximada de $800 \mathrm{~km}^{2}$, sendo considerado como um dos maiores do mundo, formado quase exclusivamente de rochas nefelinicas. Possui forma eliptica, com $35 \mathrm{~km}$ no sentido Nordeste-Sudoeste e $30 \mathrm{~km}$ no sentido Noroeste-Sudeste.

Na ärea mapeada áparece parcialmente, representa do por sua porção Sudeste.

\section{IV.5.2 - Correspondência Geomorfolögica}

Tambēm corresponde à ārea de "mares de morros".

\section{IV.5.3 - Relações de contato}

Sem entrar em detalhes sobre a evolução do maciço alcalino podemos afirmar que as relações de contato com todas as unidades mapeadas $\vec{e}$ de natureza discordante e intrusiva.

\section{IV.5.4 - Litologia}

As rochas alcalinas na ārea mapeada são constituídas, em sua maior parte, por tinguaitos. Em menor quantidade ocorrem nas bordas da intrusão, nefelina sienito fino, (afloramento 240) e fonōlitos ao Norte de Andradas.

Os tinguaitos são rochas maciças, variando de termos finos a mëdios, podendo-se observar no campo, nos termos de granulação mëdia, ser a composição mineralögica provāvel cons 
tituỉda por feldspato potässico e piroxênios. As vezes estas ro chas apresentam diversos estāgios de bauxitização.

As ocorrências de bostonito estão associados aos pontos de ocorrência de material interpretado no campo como sen do brechas alcalinas e tambëm junto ao corpo de arenito próximo ao Grande Hotel em Pocinhos do Rio Verde.

O nefelina sienito é maciço, sendo sua ocorrēncia restrita. Apresenta coloração cinza claro e é composto essencialmente por feldspato potássico e piroxénio em menor quantidade.

\section{IV.6 - Estruturas Geolögicas}

IV.6.1 - Disposição dos Corpos

Analisando-se o mapa geolōgico anexo, verificase que a disposição dos granitos porfiróides, granitos equigránulares e sienitos è de forma semi-circular. o centro deste semi-círculo é ocupado pelas rochas sieniticas margeadas por granitos porfiróides e equigranulares que por sua vez são ladeados por migmatitos. As unidades acima descrita são correlacionáveis ao Ciclo Brasiliano.

A evolução geológica destas unidades, baseadas em relações de campo, evidenciam que primeiramente ocorreu a intrusão de granitos porfirōides associado à formação dos migma titos resultante da injeção irregular desses granitos em rochas pré-existentes. Posteriormente tanto os granitos porfiróides e migmatitos foram intrudidos por granitos equigranulares. 0 ūti mo evento Brasiliano foi a intrusão, com formato semi-circular, de maneira forçada, dos sienitos da Pedra Branca nos granitos porfirôides e equigranulares.

No Cretāceo Superior houve a intrusão do Maciço Alcalino de Poços de Caldas, que na ārea mapeada ē representada por sua parte oriental, de formato circular. 
Anteriormente a esta intrusão, acredita-se que os granitos porfiróides, granitos equigranulares e os sienitos tivessem uma forma circular seccionada em sua porção ocidental quando da intrusão do maciço alcalino. Como se sabe, o Maciço Alcalino de Poços de Caldas sofreu grandes abatimentos, demonstra dos pelas posições atuais dos sedimentos (Bjornberg, 1959). $\bar{E}$ bem possivel que toda a porção ocidental do Maciço Sienitico da Serra da Pedra Branca (e granitos) acompanhou este colapso. Posteriormente a região teria sido recoberta de lavas alcalinas, jā que na mesma, não existem indícios do dique anelar externo do maciço alcalino.

\section{IV.6.2 - Distribuição das Direções de Foliações ou Bandeamentos}

Pelo mapa geolögico anexo, fica evidente que a distribuição dos elementos planares corroboram a disposição semi circular tanto dos migmatitos, granitos e sienitos. Nos sienitos os mergulhos da estrutura fluidal variam desde verticais até $70 \%$ para dentro do contorno semicircular.

\section{IV.6.3 - Falhas}

Todas as falhas indicadas no mapa geolögico provēm da fotointerpretação, por diferenças de expressões morfolōgi cas do terreno. Somente duas destas falhas puderam ser identificadas no campo: uma nas proximidades de Caldas e Pocinhos do Rio Verde e outra pouco a Norte de Ibituira de Minas. As duas fa lhas aparentemente são anteriores a intrusão do Maciço alcalino de Poços de Caldas. Fica porēm evidente que existem falhas poste riores à intrusão do maciço alcalino jā que estas cortam tantó rochas Brasilianas como Cretācicas.

\section{IV.6.4 - Fraturamentos}

Apesar de não ser dada atenção especial aos sis- 
temas de fraturamentos, fica muito evidente o desenvolvimento de juntas transversais, perpendiculares ao formato semicircular do maciço sienitico,o qual è concordante com a estrutura planar de fluxo desenvolvida na rocha. Estas fraturas são verificadas tanto macro como microscopicamente. 


\title{
$V$ - PETROGRAFIA
}

\section{V.1. Migmatitos}

\section{V.1.1 - Descrição Macroscōpica}

\begin{abstract}
Conforme já citado anteriormente os migmatitos resultam da injeção de material granītico em rochas prē-existentes. Estas, chamadas de paleossoma, ocorrem como verdadeiros res tos de diversos tamanhos (atē dezenas de metros), ostentando for matos irregulares e contatos nitidos a difusos com 0 materia granitico neossomätico. As associações entre o paleossoma e neos soma, na ärea mapeada, configuram estruturas migmatiticas como
\end{abstract} as do tipo nebulitico, "schlieren", "schollen" e oftalmítico. A composição, bastante homogênea, do neossoma, é granītica a adame 1 îtica, o que ē revelado pela presença em ordem decrescente de frequéncia dos minerais essenciais; microclina, quartzo, plagioclásio e biotita. O neossoma tem aspecto maciço, equigranular,às vezes com textura porfiróide e pode conter megacristais de micro clina geminados segundo a lei de Carlsbad, neste caso, levemente orientados. As rochas constituintes do paleossoma normalmente conservam suas estruturas e texturas originais, principalmente quando o migmatito apresenta estrutura "schollen". O paleossoma, de um modo geral, apresenta estrutura gnaissica, com alternäncia difusa de leitos claros e escuros normalmente de espessuras mill mëtricas. Os leitos escuros são de coloração verde escura, compostos essencialmente por hornblenda e biotita. Plagioclásio e quartzo compõem essencialmente os leitos de coloração cinza esbranquiçado. Predominam nestas rochas a textura granoblästica,às vezes lepidoblāstica sendo que, neste caso, a biotita predomina nos leitos escuros.

\section{V.1.2 - Descrição Microscópica}

Não foi dada atenção especial à descrição micros cópica dos migmatitos jā que o tema central não visou detalhamen to desta unidade rochosa. 
0 estudo de algumas secções delgadas do neossoma revelou que sua composição é grantica e adamelítica, fato decorrente da grande variação no teor em plagioclāsio. As relações de contato entre os feldspatos, indicam que a microclina (pertîtica e com geminação em grade), ē o ültimo mineral a se cristalizar ao substituir plagioclásio, quartzo e intercrescimentos mirmequiticos formados entre eles.

0 quartzo exibe extinção ondulante. Acessoriamente ocorrem minerais opacos, hornblenda, apatita, titanita zircão, todos com distribuição homogēnea no neossoma.

Microscopicamente o paleossoma foi estudado em al gumas amostras coletadas por Ebert (1966), ao longo da rodovia Poços de Caldas-Santa Rita de Caldas.

As caracteristicas das principais variedades lito lögicas, que compõem os migmatitos, são sucintamente descritos a baixo:

\section{- Anfibolitos}

Apresentam estrutura maciça a gnäissica e textura granoblástica. São compostos essencialmente por andesina sōdi ca e hornblenda com granulação um pouco maior que a dos plagiocläsios. A hornblenda exibe fraca extinção ondulante e está asso ciada aos plagioclásios por justaposição. Como acessōrios ocorrem: a biotita, a qual parece substituir a hornblenda; diopsidio que ocorre sempre associado à hornblenda; clorita como mineral secundārio jă que se forma nas bordas tanto dos anfibölios como das biotitas; opacos, sempre associados aos mäficos e com granulação bem inferior em relação aos outros minerais da rocha.

\section{- Hornblenda Diorito Gnaisse}

São rochas com estruturas e texturas semelhantes aos anfibolitos havendo jā uma separação incipiente entre leitos claros e escuros. A microclina e o mineral predominante: os cris tais são irregulares, à geminação em grade ē bem desenvolvida e, 
pelas relações texturais de contato, parecem substituir os plagioclāsios. Provavelmente a microclina seja oriunda da migmatiza ção sofrida por estas rochas.

Numa porcentagem bem menor ocorre oligoclāsio sendo que, em alguns cristais, foi observada geminação segundo a lei de Albita. Os plagioclásios apresentam estrutura zoneada na qual aparentemente as partes externas apresentam um teor maior em anortita. Podem apresentar intercrescimento com quartzo sob a for ma de mirmequita. A hornblenda ocorre com fraca orientação, em leitos mal definidos, com formas prismäticas euhedrais a subhe drais, entre os feldspatos.

Acessoriamente ocorrem quartzo (menos que $2 \%$ ), $0-$ pacos apatita, biotita e hiperstênio.

Foi descrita uma lâmina com caracterîsticas seme Thantes mas sem a ocorréncia de microclina, revelando ser este mineral realmente de cristalização posterior, provavelmente resul tante do processo de migmatização.

\section{- Meladioritos}

Apresentam estrutura maciça, textura granoblästi ca e a composição mineralōgica é dada por porcentagens aproximada mente iguais dos minerais, a saber: andesina, deformadas, zoneadas, podendo mostrar-se intercrescidas com feldspato potássico sob a forma de antipertita; biotita, fortemente pleocróica, granu lação bastante variāvel, normalmente deformada e com bordas clor $\underline{i}$ tizadas; augita, de coloração levemente amarronzada, sob a forma de grãos irregulares e algumas vezes apresentando-se intercrescidos com biotita. Os minerais mäficos não ostentam nenhuma orienta ção. Apatita e magnetita são os acessōrios mais comuns.

\section{V.2 - Granitos Porfiróides}

\section{V.2.1 - Descrição Macroscōpica}

São rochas de estrutura porfiróide com megacris- 
tais de microclina, rosados, numa matriz acinzentada de granulação mëdia a grossa. Ocasionalmente alguns afloramentos não exibem megacristais de microclina. A textura è inequigranular xenomörfica (matriz), hipidiomörfica (megacristais). Apresentam- se levemente orientadas segundo o alongamento dos megacristais. Com posto essencialmente por megacristais de microclina, numa matriz de oligoclásio, quartzo e biotita. opacos, apatita e zircão são os acessórios mais comuns.

Na estrada que liga a cidade de Caldas a Pocinhos do Rio Verde estes granitos exibem uma orientação mais pronunciada com aspecto cataclästico.

A ocorrência de impurezas anfiboliticas de formas e dimensões irreguiares, com contatos difusos podem ser observadas no interior destes corpos.

\section{V.2.2 - Descrição Microscōpica}

A descrição microscópica dessas rochas revela atravēs das suas relações estruturais e texturais, que os megacristais de microclina são de formação posterior em relação à matriz, pois nos contatos externos, às vezes semi-ovalados, pequenos cristais de biotita dispõem-se concordantemente ao contor no. As rochas entre Caldas e Pocinhos do Rio verde realmente revelaram ser de caräter cataciāstico, com forte extinção ondulante do quartzo e deformação dos plagiocläsio. Este fato parece näo acontecer com a microclina indicando mais uma vez sua crista lização posterior. A matriz revelou ser de composição granodior tica jă que o feldspato predominante $\bar{e}$ a andesina.

Uma breve descrição dos constituintes do granito porfirōide segue abaixo:

\section{- Microclina}

Forma os grandes megacristais da rocha, caracte- 
risticamente euhedrais e subhedrais. Mostram geminação Carlsbad e em grade bem desenvolvida alēm de algum intercrescimento com albita sob a forma de pertita. Normalmente ocorrem em cristais individuais, com seus contatos externos rodeados por biotita. A microclina ainda pode ocorrer, numa proporção bem menor, disper so na rocha sob a forma de pequenos cristais anhedrais, somente com geminação em grade, associados ao quartzo e andesina, estes com bordas de corrosão evidenciando substituição. Este fenómeno se manifesta em maior proporção entre Caldas e Pocinhos do Rio Verde, indicando na realidade tratar-se de blastoclasitos. E frequente tanto nas bordas dos megacristais como nos cristais de granulação menor a ocorrēncia de mirmequita, a qual aparente mente está sendo substituida. Quando alterados os feldspatos potássicos apresentam-se caolinizados.

\section{- Plagioclásios}

Os plagioclásios são os minerais que predominam na matriz destes granitos. (Microfotografia 1) Na sua maioria são cristais anhedrais, raramente subhedrais nos termos de granulação mais grossa. (Microfotografia 2) Apresentam geminação polissintética segundo a lei de Albita (010) bem desenvolvidas, mas normalmente deformadas. Geminação segundo a lei de Periclina (001) em indîividuos que apresentam geminação albita ē raro. 0 àngulo de extinção nos plagioclásios varia de 6,5 até $25^{\circ}$, (o ligocläsio a andesina). Em alguns casos apresentam-se intercrecidos com quartzo, sob a forma de mirmequita e mesmo assim acham-se englobados pela microclina. Os plagioclāsios são os pri meiros minerais a se alterar (por sericitização) na rocha.

\section{- Quartzo}

Exibem formas totalmente irregulares, extinção fortemente ondulante (principalmente entre Caldas e Pocinhos do Rio Verdel, indicando deformações. Ocorrem sempre associados ou intercrescidos com plagioclásio ou ainda sob a forma de verdadeiros restos dentro da microclina. 


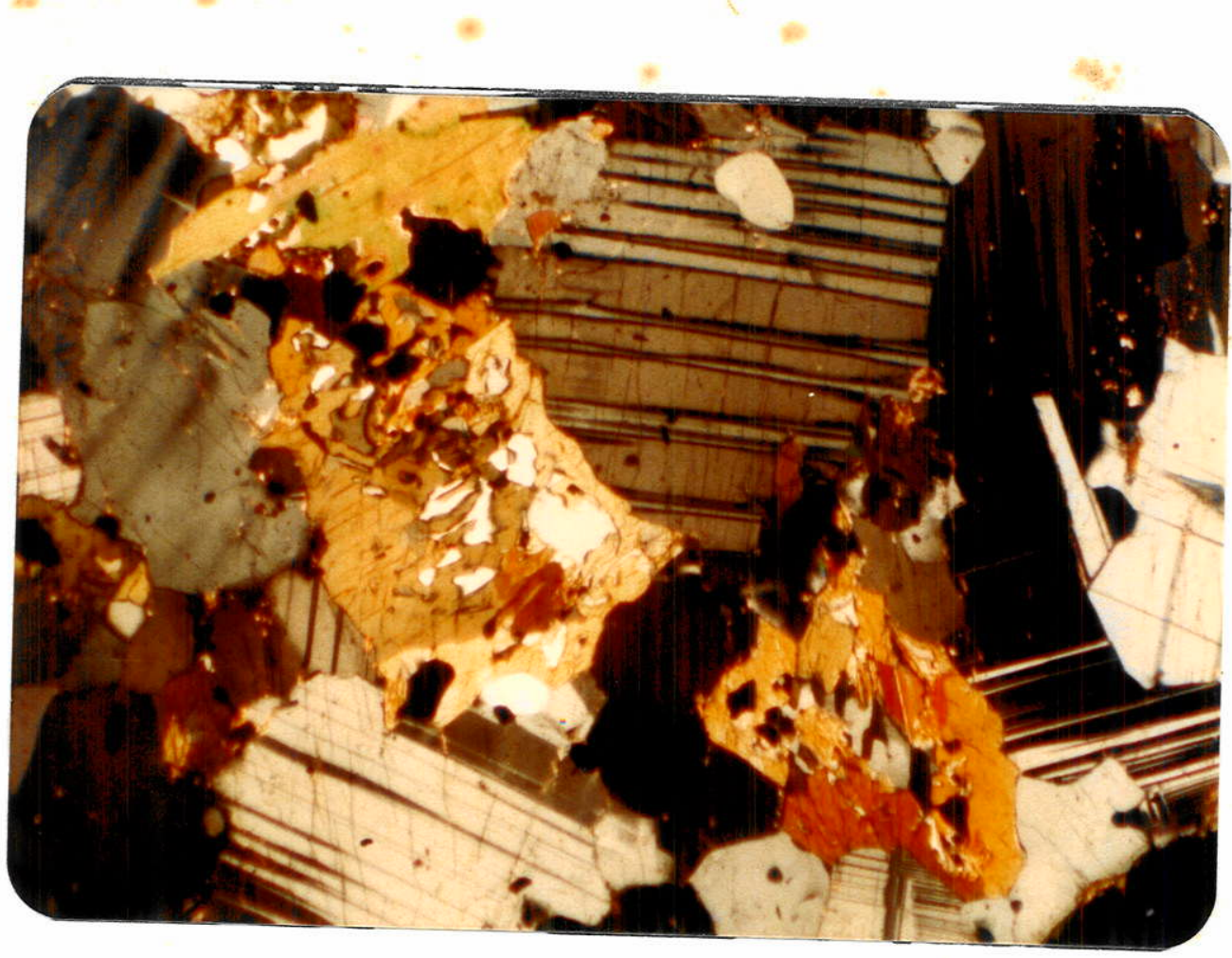

Microfotografia 1 - Granito porfirōide. Aspecto geral da "matriz" dos granitos porfirōides mostrando substituição do mineral acessório hornblenda pela biotita. Nicóis $x$, aumento $25 x$.

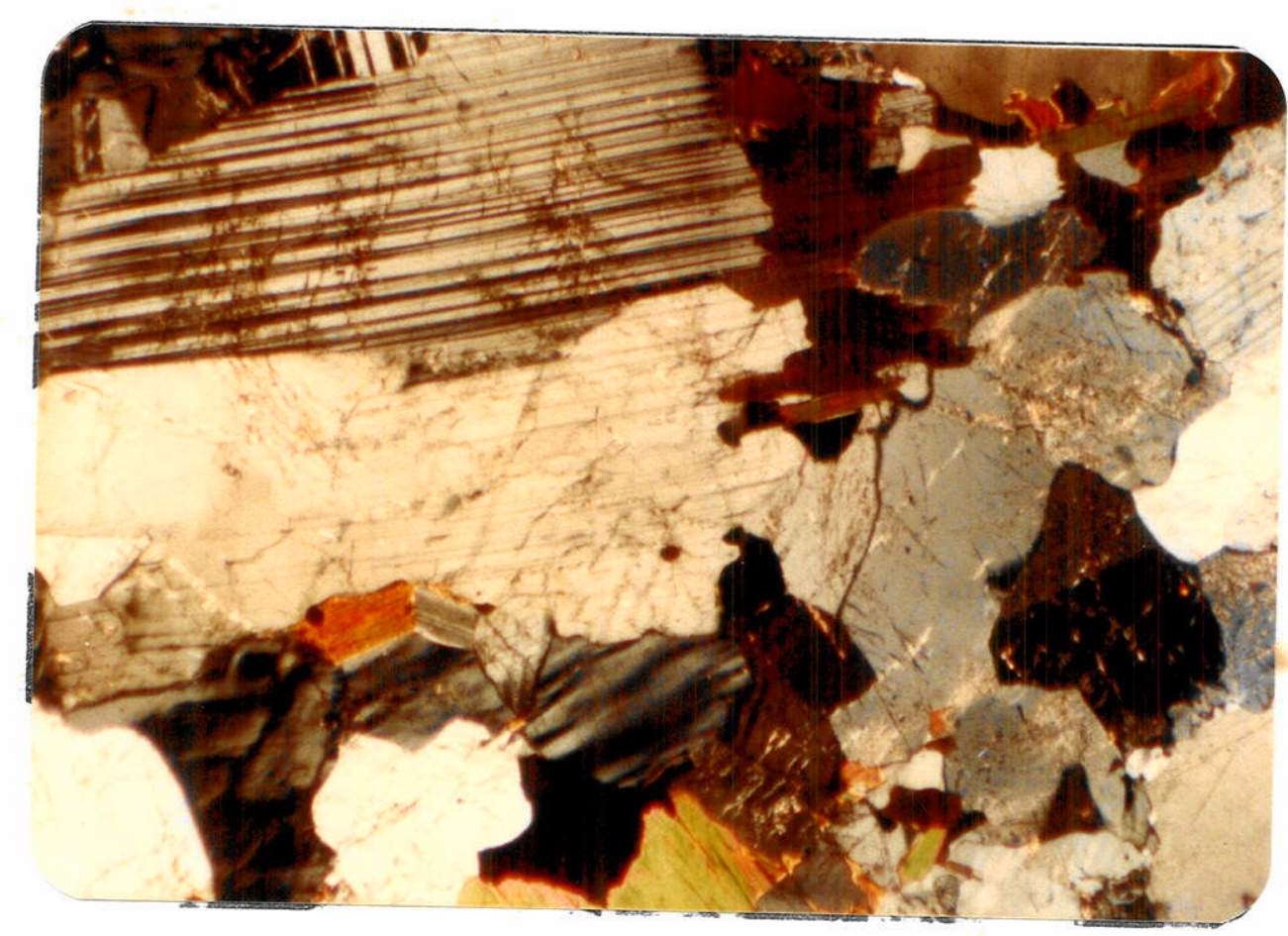

Microfotografia 2 - Granito porfiróide. Detalhe da "matriz" dos granitos porfiróides mostrando plagioclásio subhedral em contato com microclina e biotita. Nicóis $x$, Aumento $32 x$. 


\section{- Biotita}

Ocorre como mineral acessōrio sob a forma de pequenos cristais, subhedrais a anhedrais, distribuidos caoticamen te em torno de megacristais de microciina. Mesmo quando isolados não ostentam qualquer orientação preferencial, a não ser nas zonas de cataclase jā mencionadas. Normalmente apresentam bordas de alteração a clorita.

Acessoriamente podem ainda ocorrer opacos (provavelmente magnetita), hornblenda, apatita, titanita e zircão, to dos com distribuição homogênea, sem nenhuma associação preferencial.

\section{V.3 - Granitos Equigranulares}

\section{V.3.1 - Descrição Macroscōpica}

São rochas maciças, textura hipautomörfica equigranular de granulação média, podendo ocorrer termos mais finos e, raramente de granulação grossa. De um modo geral são de coloração rosada, leucocrāticos, localmente mesocrāticos devido a uma maior concentração de biotita. São compostos em ordem decres cente de frequência de; microclina, quartzo, oligoclásio e biotí ta. Mostram alguma orientação quando nas proximidades ou regiões de contato com os granitos porfiróides.

\section{V.3.2 - Descrição Microscöpica}

A descrição microscópica revelou uma composição que não pode ser correlacionada à matriz dos granitos porfirói des pois o conteúdo em plagioclásio nos granitos equigranulares é bem inferior. (Microfotografia 3 ). Por suas relações texturais parece que a microclina foi o ültimo mineral a se cristalizar nesta unidade. Individualmente o comportamento dos minerais é co mo segue: 


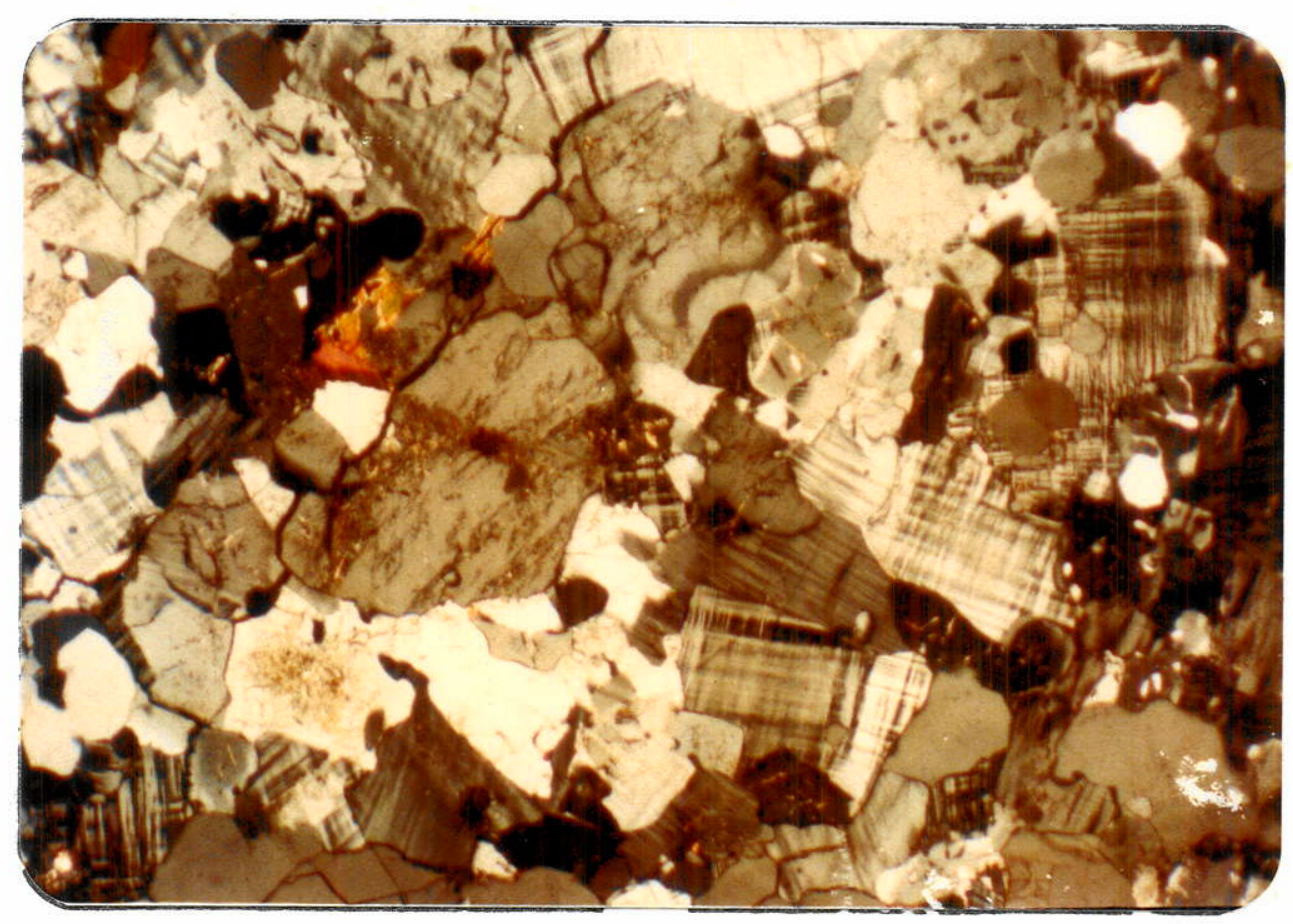

Microfotografia 3 - Aspecto geral do granito equigranular eviden ciando o amplo predomínio da microclina sobre os plagiocläsios. Nicóis $X$, aumento $10 \mathrm{x}$.

\section{- Microclina}

E visivelmente um mineral de cristalização posterior aos outros constituintes da rocha. A geminação em grade é bem desenvolvida e raramente apresenta geminação segundo a lei de Carlsbad. Os cristais demonstram pouca variação na granulação e são de forma irregular em virtude das relações de contato com quartzo e plagioclásio indicar corrosão. A microclina acha- se intercrescida com albita, esta sob a forma de micropertita.Comum é a ocorréncia dentro da microclina, de quartzo e restos de cris tais de plagioclásio exibindo geminação polissintética. Sob os efeitos de intemperismo os cristais de microclina se mostram cao linizados e/ou sericitizados.

\section{- Quartzo}

A exemplo da microclina os cristais são totalmen te irregulares. Podem ocorrer sob a forma de cristais isolados 
ou agregados, dispostos entre cristais de microclina e plagioclā sio ou ainda englobados pela microclina ou mesmo, dentro dos pla gioclásios sob a forma de mirmequita. De um modo geral apresentam extinção pouco ondulante a não ser nas proximidades ou nos contatos com granitos porfiróides, onde aquele tipo de deforma ção é mais evidente.

\section{- Plagioctāsio}

Os plagioclásios ocorrem sempre sob a forma de restitos (no interior ou nos espaços intercristais de microcli na) ou intercrescidos com quartzo nas bordas dos feldspatos potāssicos, quando configuram arranjo ou textura mirmequítica. São cristais anhedrais, muito irregulares e ostentando geminação po lissintética desenvolvida segundo a lei de Albita. Os ângulos de extinção, medidos nesses minerais, demonstram tratar-se de oligo clásio. Os plagioclāsios são os minerais que apresentam maior es tado de alteração, estando normalmente sericitizados.

\section{- Biotita}

E representada por cristais que formam finas lamelas de contornos irregulares distribuidas homogeneamente na rocha, sem orientação preferencial, a não ser nas proximidades dos contatos com os granitos porfiróides onde exibem uma fraca orientação e extinção levemente ondulante. Apresentam pleocrois mo marrom escuro a marrom claro. Normalmente as bordas das bioti tas estão cloritizadas.

\section{- Acessörios}

Nos granitos equigranulares os acessōrios mais comuns são; opacos, apatita, titanita, hornblenda e zircão,todos com distribuição homogênea na rocha. As dimensões dos minerais a cessórios são menores que as dos minerais essenciais e sua for mas são irregulares. Os minerais opacos (provavelmente magneti ta), quase sempre ocorrem associados a biotita ou hornblenda. 


\section{V.4 - Maciço Sienítico da Serra da Pedra Branca}

\section{V.4.1 - Descrição Macroscōpica}

As rochas do maciço sienïtico ostentam estrutura fluidal, com nîtida orientação dos feldspatos de aspecto tabular, segundo seus planos (010), ficando os outros minerais encaixados ao longo destes planos (Fotografia 4). Esta estrutura acha-se melhor desenvolvida no contato externo do maciço onde acompanha a orientação do próprio contato. No centro do maciço a estrutura fluidal acha-se menos desenvolvida, com orientação não definida, havendo mudanças direcionais mesmo em escala de aflora mento.

A textura, como jā mencionada, ē hipidiomōrfica, inequigranular com granulação média a grossa.

Macroscopicamente distingue-se o feldspato potás sico de coloração rosa, aspecto tabular muito bem desenvolvido, geminação evidente, com orientação plano paralelo entre eles,podendo atingir atē $2 \mathrm{~cm}$ de comprimento segundo (010). Anfibōlios e piroxênios ocorrem associados, normalmente com contatos por justaposição aos feldspatos potássicos, ambos com forma prismāti ca, nem sempre acompanhando o alongamento dos feldspatos. Distin gue-se anfibōlios de piroxênios, pelo fato do primeiro ser de có loração verde mais escura que os piroxênios e pelo ângulo de cli vagens. A biotita é facilmente identificāvel pela sua coloração preta, clivagem em placas segundo (001), brilho caracteristico, normalmente com orientação concordante aos feldspatos. Pontuações submilimétricas de apatita, titanita e quartzo, com distribuição homogênea, às vezes são reconhecidas macroscopicamente nos termos de granulação mais grossa.

\section{V.4.2 - Descrição Microscōpica}

o levantamento microscópico dos sienitos da Pedra Branca revelou a existência de um zoneamento mineralógico do corpo como um todo. A parte externa deste maciço, isto é, próxi- 


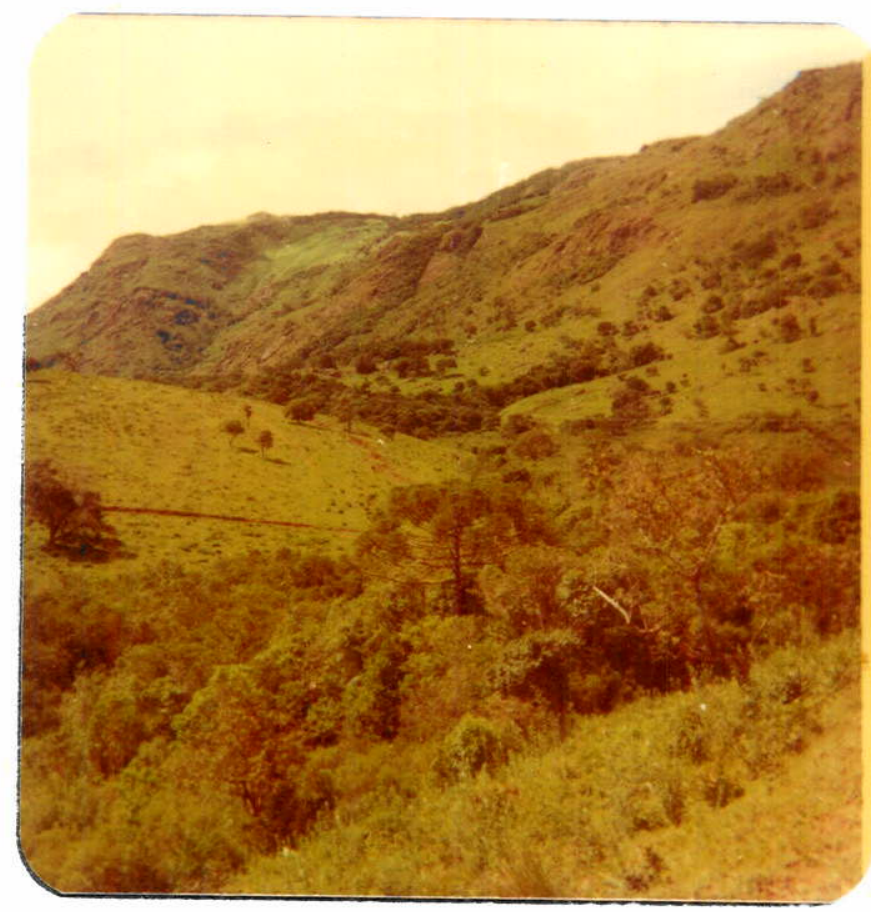

Fotografia 3 - Região de contato entre os granitos e sienitos on de se nota a brusca mudança de relevo próximo ao afloramento 115 . Os sienitos se encontram à direi ta na foto (NE).

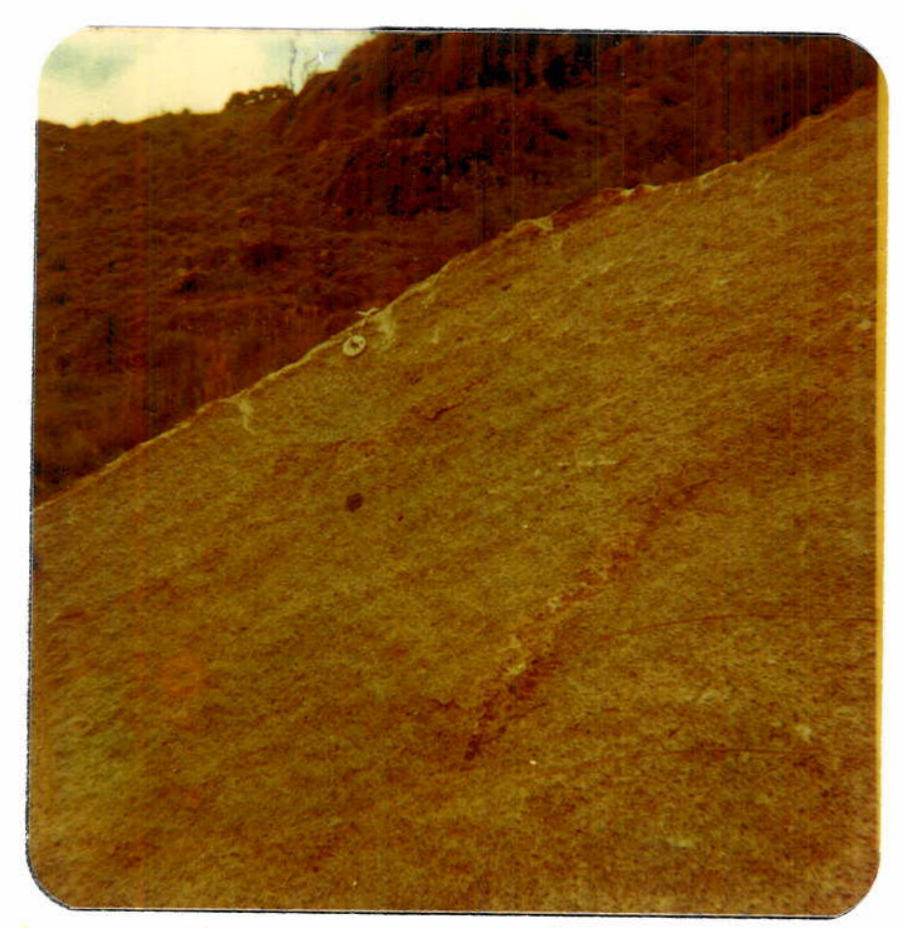

Fotografia 4 - Aspecto geral do sienito em matacão partido mostrando estrutura fluidal e pequenos "xenólitos". 
mo ao contato semicircular com as rochas graniticas, é composta de rochas saturadas (sem quartzo), insaturada num ūnico afloramento (A-115) onde foi determinado o feldspatöide nefelina. 0 mäfico característico destas rochas saturadas e insaturadas $\bar{e}$ a aegirina-augita. 0 anfibólio, hornblenda, ē por vezes azulada e, neste caso seria possivelmente mais sódico, podendo correspon der a uma eckermanita. Entre os māficos essenciais ocorre ainda a biotita. A estrutura, ao microscōpio, tambēm evidencia uma forte estrutura fluidal, com orientação plano paralela, tabular segundo (010) dos feldspatos potāssicos, porēm sem deformação tectónica, nem nos feldspatos nem no restante dos minerais que compõem a rocha. A composição modal caracteriza volumetricamente os constituintes mineralógicos desta zona, assim como a varíação da proporção entre os diversos minerais mäficos. Para a ausēncia em certas amostras, de alguns destes mäficos, não temos explicação no momento (vìde tabela 1).

Na parte interna do maciço, mesmo no contato com o Maciço Alcalino de Poços de Caldas, o sienito mostra- se saturado a supersaturado chegando em alguns locais a conter ate $6 \%$ em quartzo. O diopsĩdio ē o māfico caracterīstico da zona; tambëm, ocorrendo variavelmente, biotita ou hornblenda. A peque na saliência a Sudoeste de Caldas mostra-se supersaturada. Tambëm nesta região interna, os feldspatos potässicos são mais intensamente pertiticos que na zona externa do maciço. A estrutura fluidal nesta região mostra-se menos desenvolvida que na par te externa mas sempre com uma ligeira orientação plano parale1a. A textura revela-se semelhante àquela descrita macroscopica mente. A composição modal das rochas da parte interna do maciço sienitico acha-se na tabela 2 .

A caracterização de cada constituinte mineralógico do maciço sienitico é como segue abaixo:

\section{- Ortociàsio}

E o mineral que predomina na rocha. Baseado em estudos atravēs da platina de Federoff com auxîlio da projeção estereogräfica, o feldspato demonstrou simetria monoclinica e 
TABELA I - COMPOSIÇAO MODAL DOS SIENITOS SATURADOS A INSATURADOS

\begin{tabular}{|c|c|c|c|c|c|c|c|c|c|c|c|c|c|c|c|c|c|c|c|}
\hline Minerais & OF-185 & $A-115 b$ & A-89 & $A-185$ & $A-305$ & A & $A-93$ & $A-146$ & $A-151$ & $A-187$ & $A-171$ & $A-136$ & $A-97$ & $\mathrm{Cd}=120$ & $c d-119$ & $A-88$ & $A-227$ & $A-62$ & $A-174$ \\
\hline Ortoclāsio & 72,82 & 70,04 & 80,16 & 71,38 & $.73,82$ & 70,16 & 68,43 & 72,84 & 68,48 & 72,87 & 66,93 & 75,78 & 71,25 & 69,06 & 83,06 & 78,27 & 65,15 & 87,59 & 72,26 \\
\hline Plag & 2,27 & 0,31 & - & 1,46 & 1,81 & 2,75 & 2,42 & 1,36 & 0,52 & & - & 0,62 & 3,53 & & & - & 0,20 & 4,42 & - \\
\hline Biot & 2,44 & 6,36 & 2,25 & 3,17 & & - & 4, & 09 & & 5,70 & 1,61 & 83 & 1,22 & 2,97 & 2,90 & - & 6,84 & 0,70 & 0,59 \\
\hline Hornblenda & - & & 3,81 & - & 8,60 & 12,21 & 0,15 & 1,60 & 0,07 & - & 15,93 & 0,24 & 10,15 & & - & 10,20 & - & 0,56 & 13,58 \\
\hline Aegirinà-Augita & 15,16 & 14,13 & 8,73 & 17,05 & 7,50 & 0,01 & 17,25 & 14,32 & 14,26 & 16,10 & 5,15 & 11,47 & 6,87 & 17,72 & 9,36 & 4,76 & 18,77 & 5,61 & 7,86 \\
\hline Titar & 3,14 & & 0,62 & 1,52 & 97 & 2,75 & 2,42 & 0,86 & - & 1,88 & 5,42 & 2,28 & 3,89 & 2,49 & 1,34 & 1,28 & - & 0,56 & 0,96 \\
\hline Apa & & & 2,6 & 2, & & & & & 14 & 2,26 & 2,74 & 1,99 & 1,94 & 4,12 & 1,64 & 0,91 & 5,56 & 0,28 & 1,19 \\
\hline $0 p$ & 2,00 & 0,94 & 1,81 & 2,44 & 1,87 & 1,66 & 2,86 & 2,7 & 4,05 & 1,19 & 2,21 & 2,80 & 1,16 & 3,64 & 1,71 & 66 & 3,39 & 0,28 & 2,74 \\
\hline Mir & - & - & - & - & . & - & - & - & - & - & - & - & - & - & - & 2,95 & - & - & 0,74 \\
\hline & - & - & - & - & 0,13 & - & - & & - & - & 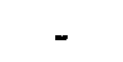 & & & & & - & 0,07 & - & 0,07 \\
\hline Nefelina & & 2,33 & - & - & & - & & & -. & & & & . & & - & - & - & $\therefore$ & - \\
\hline
\end{tabular}


TABELA 2 - COMPOSIÇAO MODAL DOS SIENITOS SATURADOS A SUPER SATURADOS

\begin{tabular}{|c|c|c|c|c|c|c|c|c|c|c|c|c|c|c|c|c|}
\hline minera is Amostra & $C d-125$ & $A-290$ & $O F-184$ & $A-291$ & $A-82$ & $A-81$ & $A-279$ & $A-275$ & A-263 & $A-253$ & $A-245$ & A-172 & $A-251$ & $C d-122$ & A-207 & $C d-121$ \\
\hline Ortocläsio & 76,15 & 71,97 & 76,22 & 79,17 & 73,26 & 72,55 & 72,89 & 73,33 & 73,53 & 65,45 & 66,77 & 74,00 & 75,88 & 72,29 & 73,82 & 81,81 \\
\hline Quartzo & 2,17 & 3,70 & 0,22 & 2,43 & 4,69 & 1,63 & 2,40 & 3,16 & 0,25 & 2,92 & 0,84 & 6,08 & - & 0,50 & 6,12 & 0,70 \\
\hline Plagiocläsio & 2,70 & - & 1,26 & 0,49 & - & - & - & - & 0,50 & - & 5,46 & 3,69 & - & 0,92 & - & 0,82 \\
\hline 8 iotita & 3,69 & 0,16 & 2,34 & 2,43 & 0,13 & 0,82 & 6,36 & 3,16 & 0,50 & 2,12 & 5,69 & 3,48 & 3,59 & 0,28 & 2,15 & 0,06 \\
\hline Hornblenda & 3,41 & 11,59 & 0,25 & 2,78 & 14,08 & 14,67 & 1,56 & 2,88 & 4,44 & 16,37 & 0,76 & 2,68 & - & 12,69 & 6,06 & 3,92 \\
\hline Diopsidio & 6,96 & 5,44 & 13,63 & 7,71 & 1,41 & 5,71 & 10,32 & 9,25 & 14,99 & 5,19 & 15,40 & 6,52 & 13,88 & 7,94 & 3,47 & 8,78 \\
\hline Titanita & 0,28 & 0,36 & 0,02 & 0,63 & 1,28 & - & - & - & 0,84 & 0,22 & - & - & - & 0,07 & - & 1,01 \\
\hline Apatita & 2,56 & 2,42 & 4,12 & 1,81 & 2,18 & 1,36 & 1,88 & 1,64 & 2,26 & 1,68 & 1,97 & 1,30 & 2,15 & 2,41 & 1,53 & 1,39 \\
\hline opacos & 1,99 & 2,00 & 1,97 & 2,43 & 1,28 & 1,09 & 2,09 & 3,48 & 2,68 & 1,83 & 3,11 & 2,17 & 4,50 & 2,91 & 2,71 & 1,52 \\
\hline Mirmequita & - & 2,26 & - & - & 1,61 & 1,90 & 2,45 & 3,00 & 3,22 & - & - & - & - & - & 2,08 & - \\
\hline Zircão & - & 0,10 & - & 0,07 & 0,06 & 0,27 & 0,05 & 0,09 & - & - & - & 0,07 & - & - & - & - \\
\hline
\end{tabular}


geminação segundo a lei de Carlsbad, o ânguto 2 V determinado, va ria de 60 a $78^{\circ}$ indicando que estes feldspatos pertencem à sérié ortoclāsio-micropertita com 30 a $50 \%$ do componente albita (Heinrich, 1965). Como os sienitos são compostos, na sua grande maioria, por um único feldspato, o magma deveria, segundo Heinrich (1965), ter-se cristalizado sob condições "hiper-solvus" (temperaturas altas e pressões baixas), permitindo entretanto um resfriamento suficientemente lento para que atingida a temperatura do "solvus" o feldspato exsolva o componente albita.

0 ortoclásio ocorre sob a forma de grandes cristais euhedrais a subhedrais com até $2 \mathrm{~cm}$, tabulares, alongados segundo uma orientação preferencial. (Microfotografia 4). Quase todos os indivĩduos, apresentam um único plano de geminação, nor malmente não retilíneo, planos estes paralelos a (010) (Microfotrografia 5). Tambēm formam grãos menores, anhedrais, normalmente concentrados, sem geminação e intercrescidos de maneira irregular, associados ou não aos cristais maiores de ortocläsio. A maioria dos cristais apresenta intercrescimento micropertitico, em forma de filmes que normalmente cortam de maneira perpendicular as linhas de geminação. Ao longo destas linhas não hā, em geral, deslocamento dos filmes de albita, o que sugere uma prova vel geminação anterior ao intercrescimento pertitico. A porcenta gem de albita pertítica na parte central do maciço sienitico $\bar{e}$ superior é observada na zona externa onde, às vezes, o ortociásio se isenta de albita. Aqui, alternativamente, nūcleos de orto clásio homogêneo se enriquecem perifericamente de albita pertíti ca chegando, algumas vezes a se observar pequenos cristais individualizados de albita nas bordas do feldspato potássico. Os feldspatos onde este fenomeno ocorre, apresentam estrutura de crescimento em zonas. O crescimento concêntrico parece ser anterior à geminação, visto que, nos planos de composição estas estruturas estão um pouco deslocadas de um individuo para outro.

Individualmente os cristais de ortociásio, pertí ticos ou não, apresentam estrutura poiquilitica, devido a existência de agulhas e "pingos" de material não identificāvel microscopicamente (Microfotografia 6). As agulhas são de material transparente, relevo alto, birrefringência forte, com alongamen 


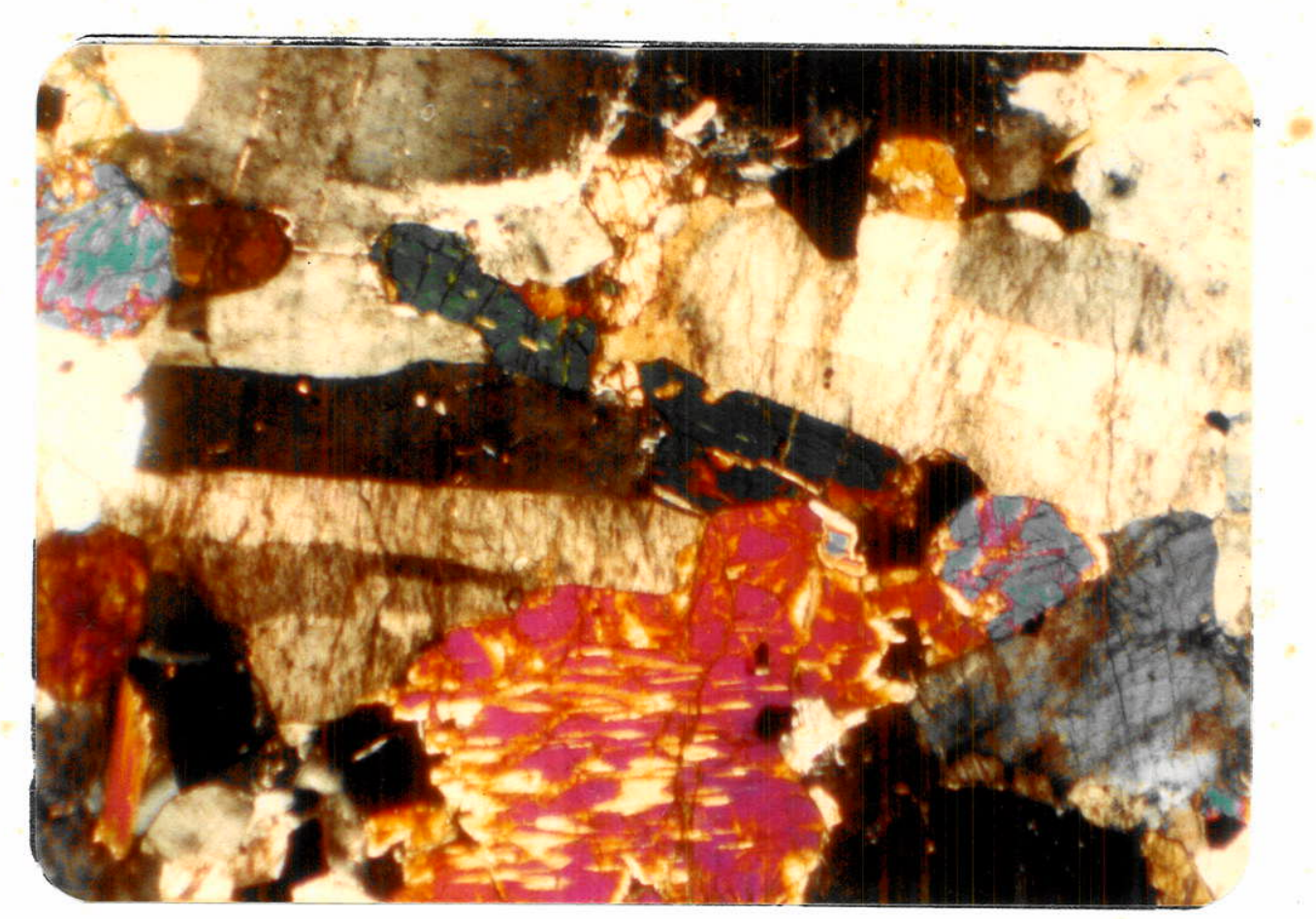

$-52-$

Microfotografia 4 - Sienito fluidal com cristais alongados e tabulares de ortoclásio, com geminação Carls bad. As fraturas são perpendiculares ao alongamento dos feldspatos. As partes mais claras dos piroxênios indicam início de sua substituição pela biotita. Nicóis $x$, aumento $10 x$.

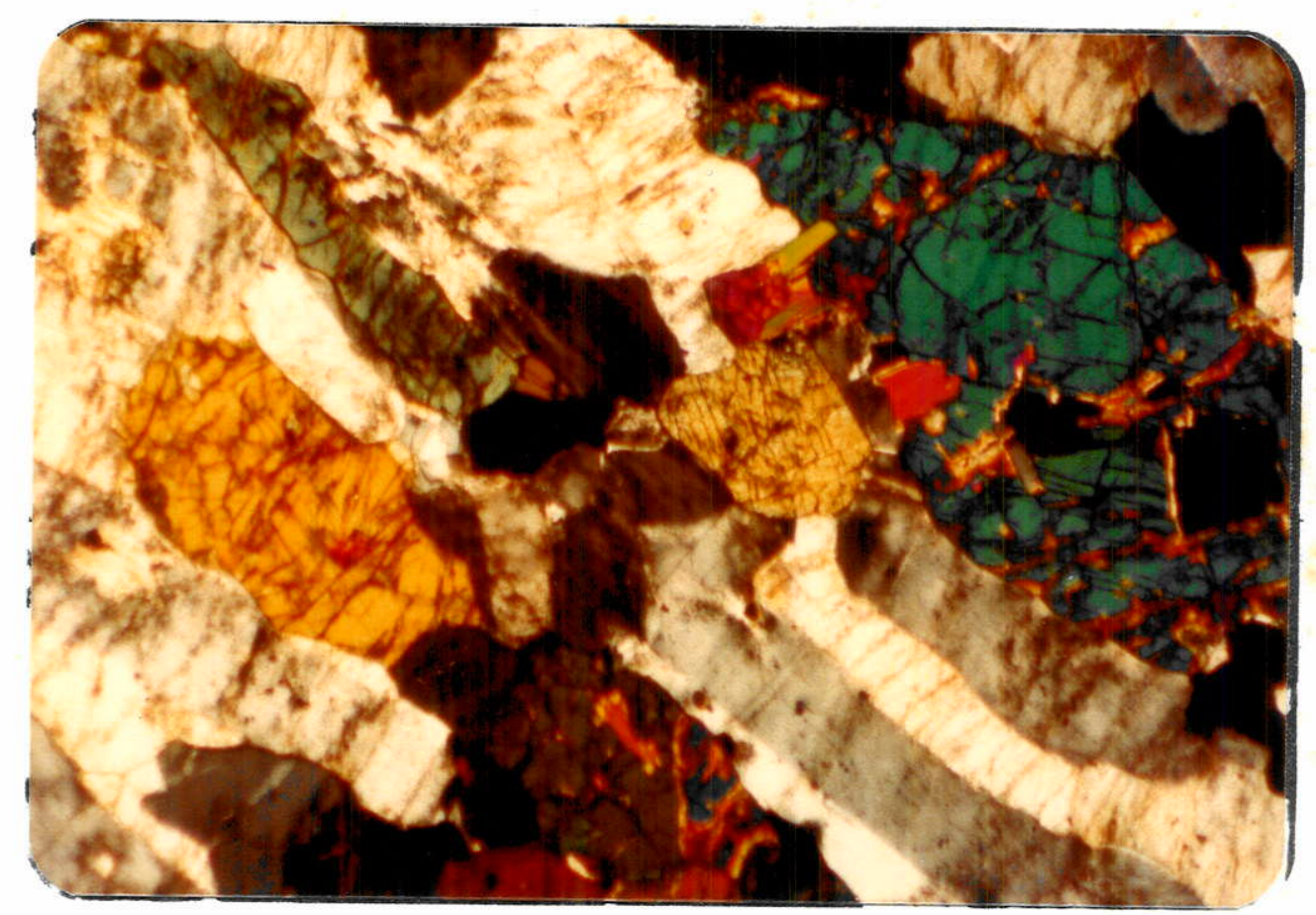

Microfotografia 5 - Sienito mostrando estrutura fluidal na qual fica evidente que os planos de geminação dos feldspatos não são retilineos e as fraturas são perpendiculares a estes planos. Nicóis $X$, aumento $10 \mathrm{x}$. 


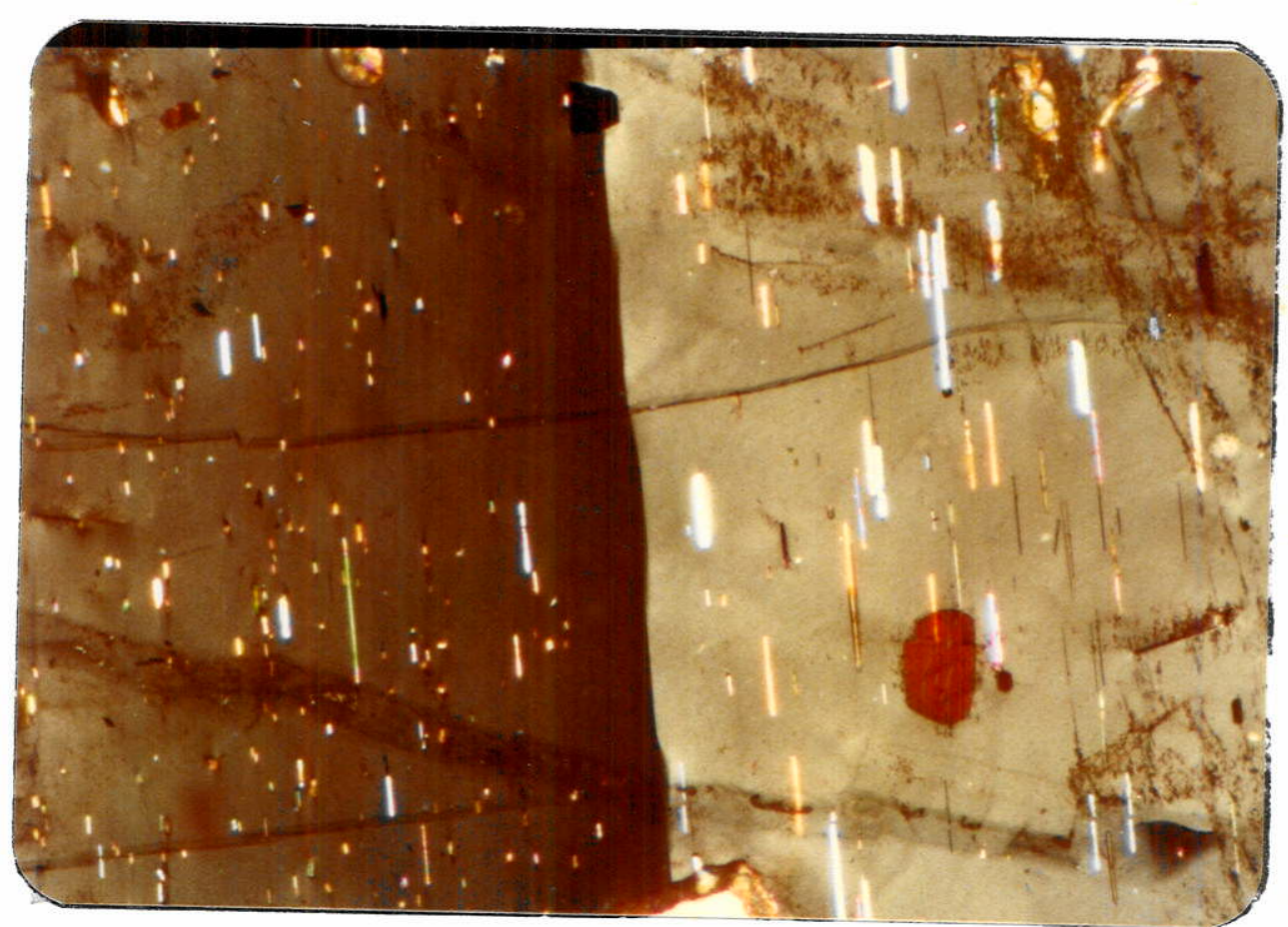

Microfotografia 6 - Cristal de ortoclásio mostrando crescimento de "agulhas" e "pingos" de material não identificāvel, além de opacos. Dentro do "pingo" há textura de exsolução. Notar plano de geminação não retiliñeo e fraturas per pendiculares ao plano de geminação.Nicōis $X$, aumento $100 \mathrm{x}$.

to paralelo ao alongamento do cristal (rutilo?). Os "pingos" aparentemente são de material sub-opaco, cor amarronzada, formas variadas desde quadrados até arredondados. Os "pingos" exibem texturas de exsolução evidenciado pelos contatos nitidos entre termos de coloração marrom escura e marrom médio (microfotografia 6).

E frequente o fraturamento nos feldspatos, perpendicular ao alongamento e às linhas de geminação. (Microfotografias 4,5 e 6). Fenōmenos de sericitização e caolinitização são comuns nos termos semi decompostos e decompostos. 


\section{- Diopsidio}

E o mineral predominante na zona interna do maci ço sienitico. Ostenta em sua maioria formas anhedrais, de granulação bastante variada, coloração verde claro, não pleocróico. Não segue com tanto rigor a orientação fluidal, ostentando por vezes disposição perpendicular dos eixos $\underline{C}$ entre eles, numa mes ma amostra (Microfotografia 7). Os piroxênios mostram linhas de clivagem bem desenvolvidas, nas secções basais (Microfotografias 7 e 8 ).

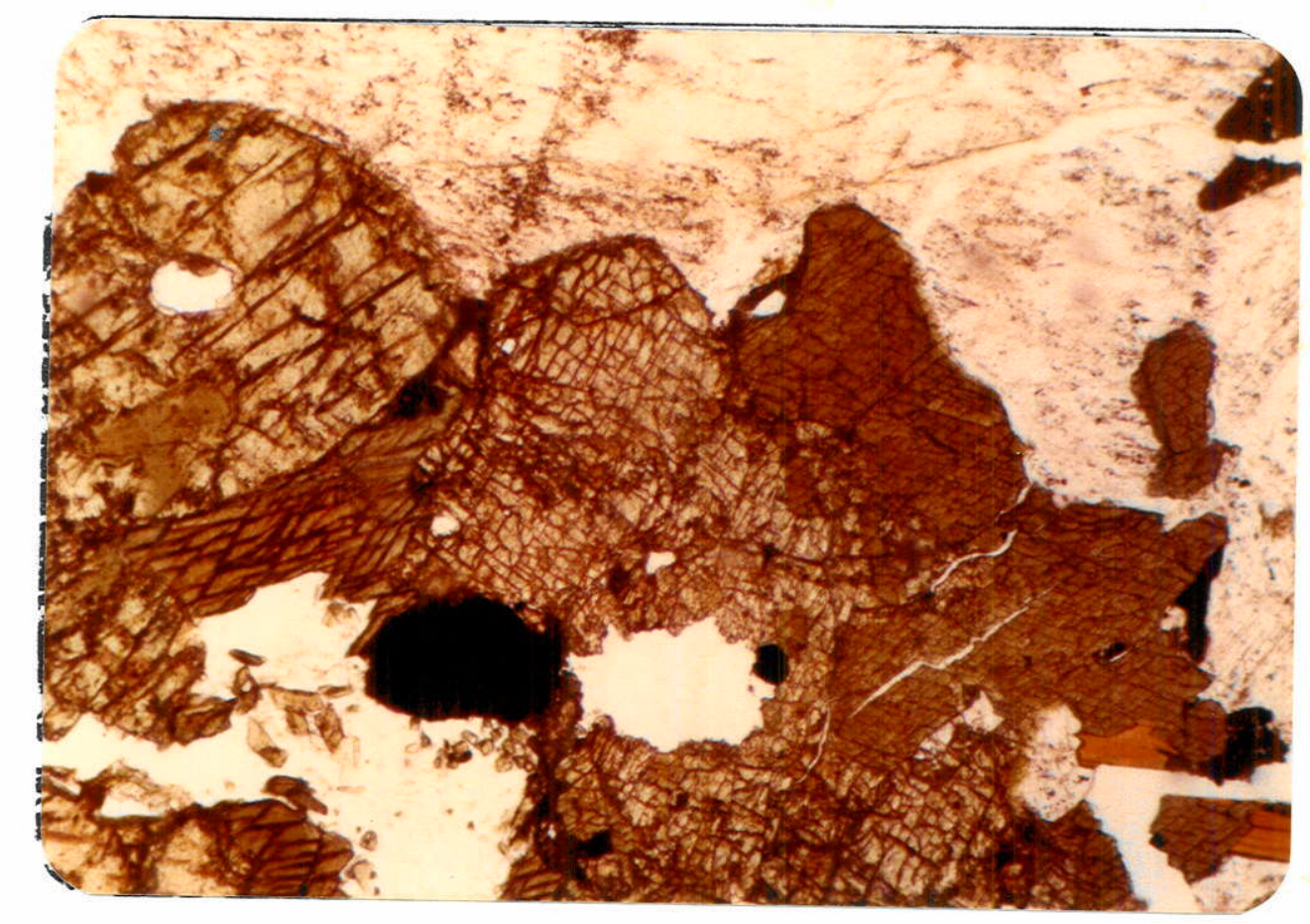

Microfotografia 7 - Diopsídio e hornblenda mostrando secções basais com linhas de clivagem bem desenvolvi das com o segundo substituindo o primeiro, $\underline{e}$ videnciando também a disposição ortogonal en tre os piroxēnios.

o diopsỉdio sempre ocorre associado a outros mäficos, raramente isolados, neste caso dentro dos cristais de ortociásio. A distribuição do diopsîdio com o seus associados é ho mogênea na rocha, ocorrendo entre os cristais de feldspato potás sico por justaposição. 


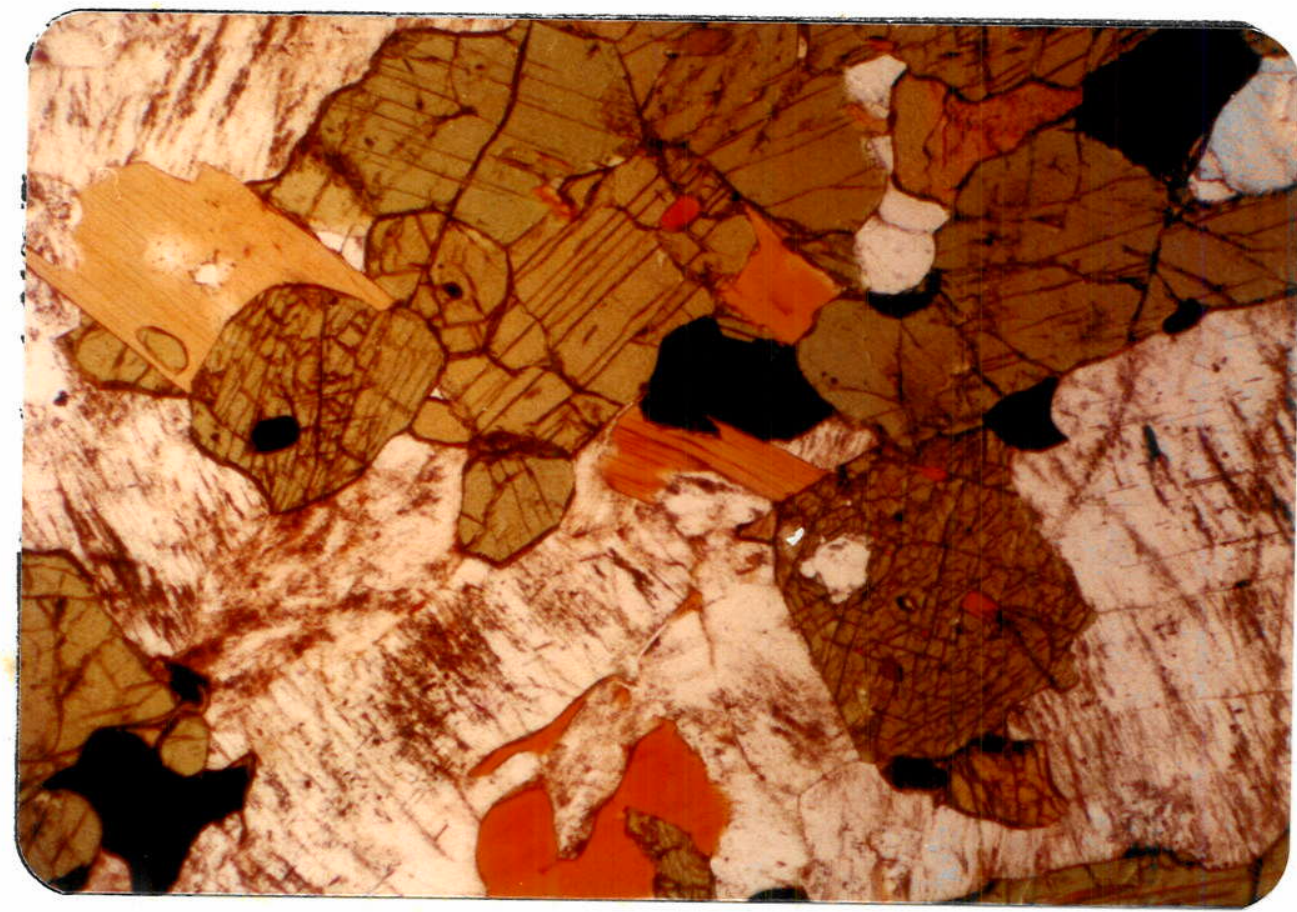

Microfotografia 8 - Substituição direta de piroxênio por biotita, que tambēm substitui a hornblenda. Notar seç̧ão basal do piroxênio com linhas de cli vagem bem desenvolvida. Nicóis //, aumento $25 x$.

Quando o diopsỉdio ocorre associado à hornblenda e/ou biotita, fica nitida a substituição do piroxênio pelos dois ūitimos, sendo o contato sempre irregular com formas de corrosão, indicando substituição (Microfotografias 7, 9, 10,11, $12,13)$. Ocorrem verdadeiros restos de diopsidio, totalmente irregulares, dentro dos cristais de hornblenda (Microfotografias $9,10,11)$. Tanto os contatos de substituição, como os verdade ros restos dentro dos anfibōlios, indicam ser o diopsídio de cristalização anterior à hornblenda e a biotita. Portanto um processo inverso caso tivēssemos um fenōmeno de fenitização.

0 diopsidio apresenta-se bastante fraturado,quase sempre em direção perpendicular ao eixo $\underline{c}$ do cristal, quando este é paralelo à orientação da rocha. Nas rochas semi decompos tas precipitou-se hidrōxido de ferro ao longo dos planos de clí vagem e fraturas. Em alguns casos as bordas do mineral estão calcitizadas. 


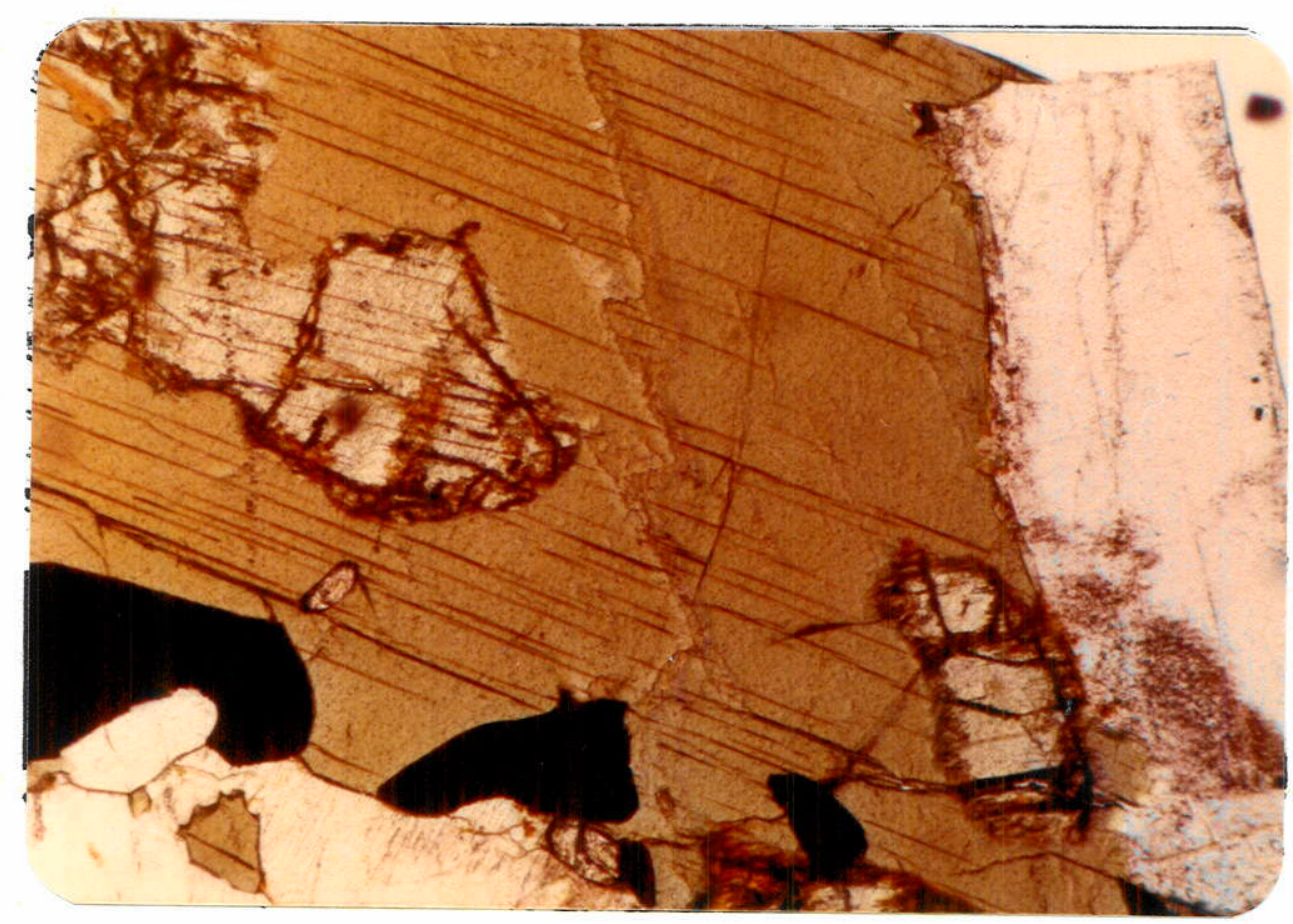

Microfotografia 9 - Substituição do piroxênio por anfibōlio.observar pequeno cristal ovalado de zircão dentro da hornblenda. Nicóis//, aumento $32 \mathrm{x}$.

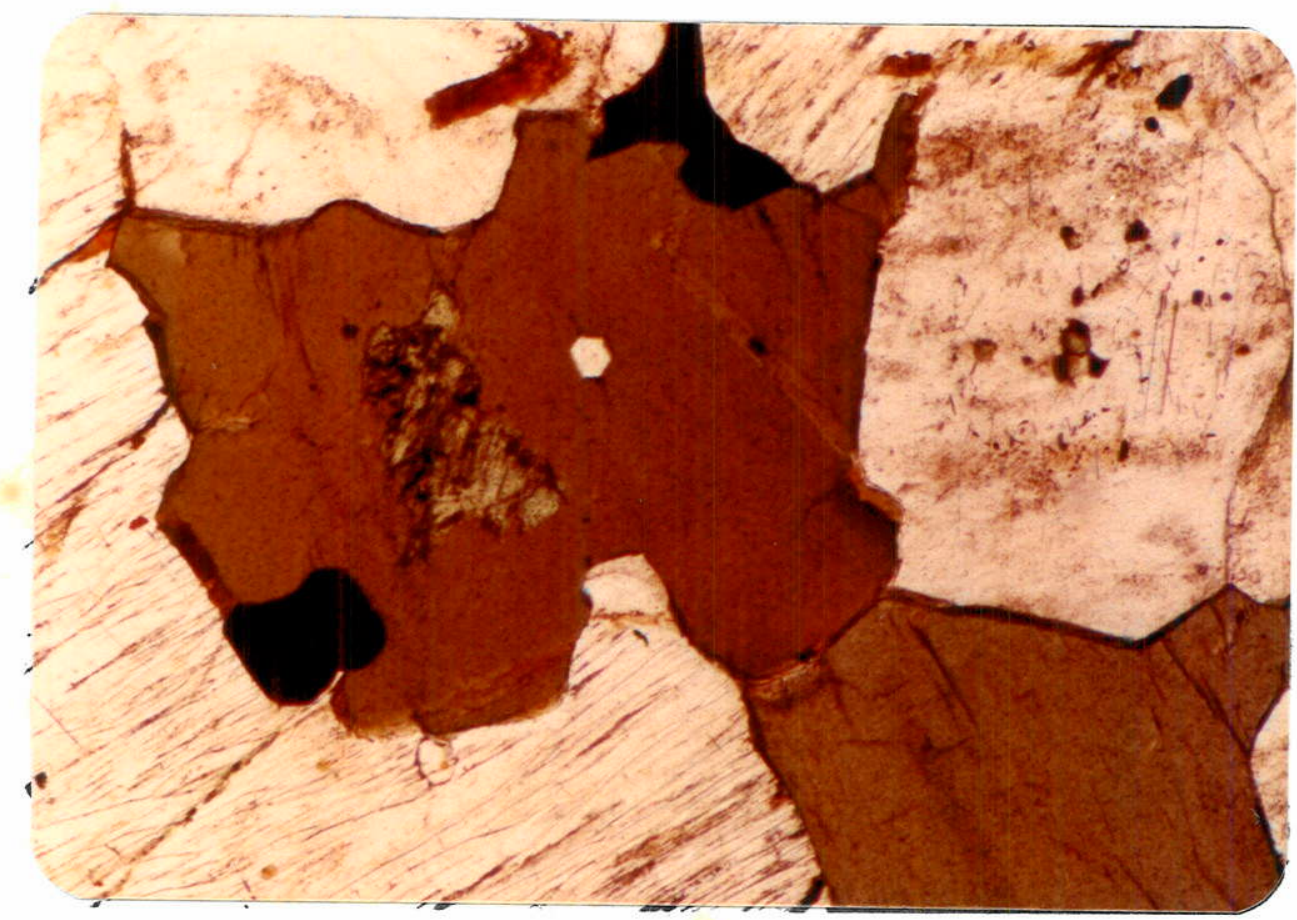

Microfotografia 10 - Verdadeiro resto de piroxênio dentro da hornblenda associada à magnetita.Nicóis//, aumento $32 \times$. 


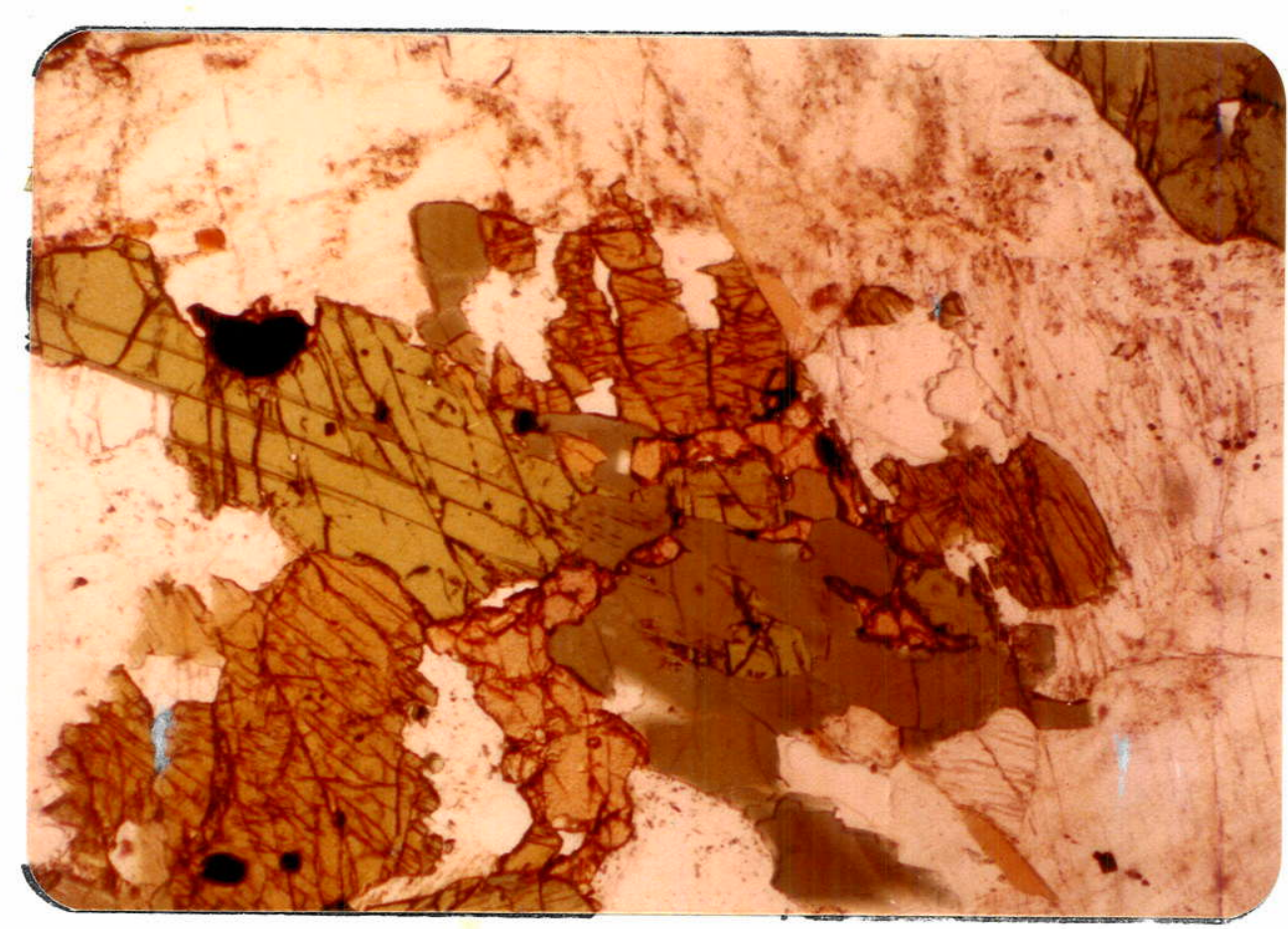

$-57-$

Microfotografia 11 - Restos de piroxênio (no caso aegirina-augita) dentro da hornblenda associada à titani ta e opacos. Nicóis//, aumento $25 \times$.

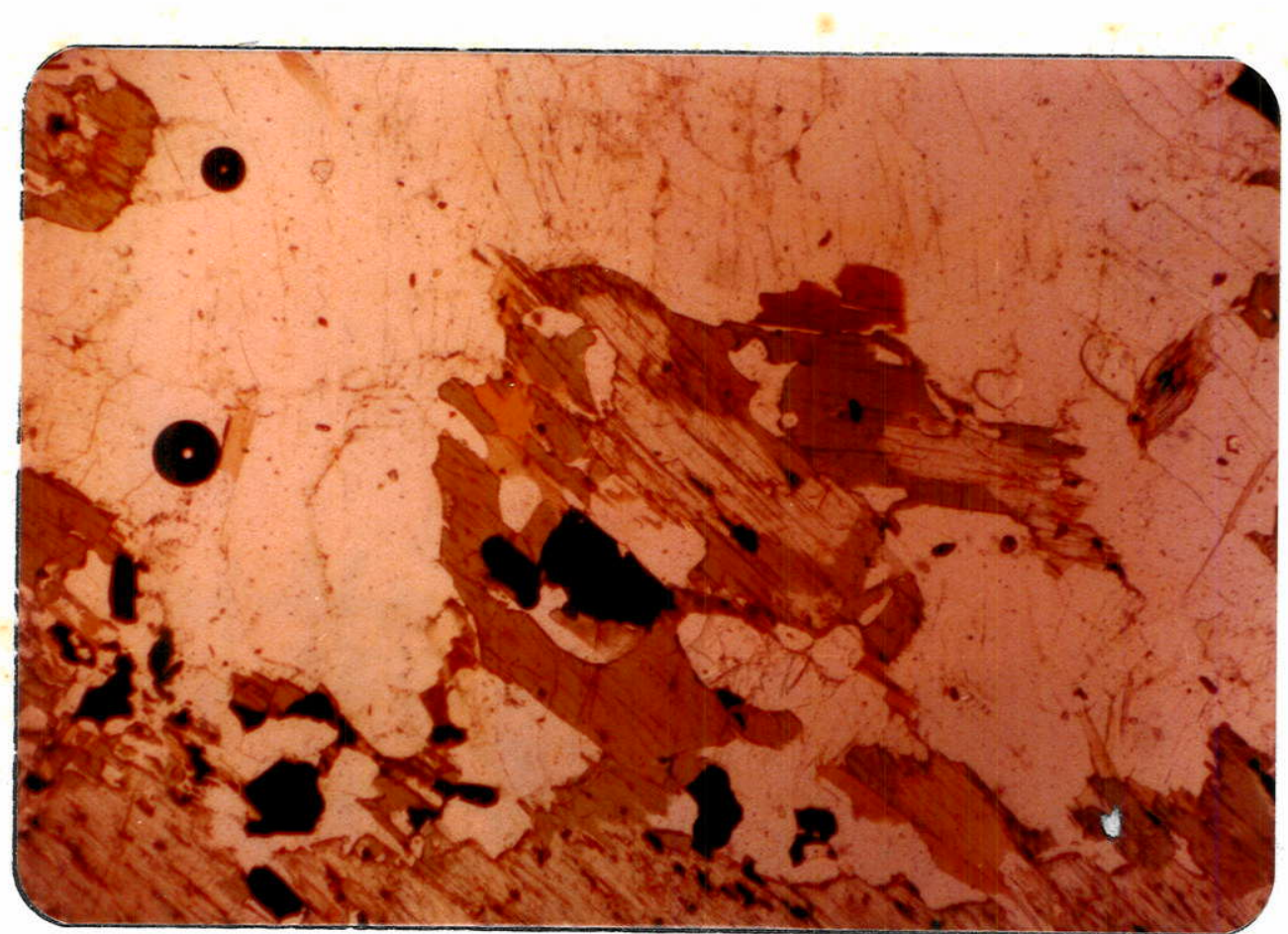

Microfotografia 12 - Substituição de piroxênio por hornblenda e deste por biotita. Nicóis//, aumento $10 x$. 


\section{- Aegirina-augita}

Como acontece com o diopsidio na parte interna,a aegirina-augita ē o mäfico que predomina na zona circular externa. As caracteristicas texturais são semelhantes ao diopsidio com exceção da coloração verde mëdio, pleocroismo fraco mas bem evidente. Nas demais características o comportamento da aegirina -augita é semelhante ao diopsídio, sendo também substituído por hornblenda e/ou biotita.

\section{- Hornblenda}

A hornblenda forma cristais anhedrais a subhedrais, normalmente de tamanho bastante variāvel, porém de um modo geral, um pouco maior que os piroxēnios, sendo às vezes geminada. 0 pleocroismo ē bem evidente. Este anfibōlio ē o mäfico que menos obedece à orientação fluidal ostentada pela rocha.Mos tra, numa mesma seç̧ão delgada, secções basais com duas direções de clivagem bem desenvolvidas, e individuos obliquos com uma só direção de clivagem ao longo do eixo $\subseteq$ (Microfotografia 7 ).

Fica muito evidente o fato da hornblenda estar substituindo tanto o diopsidio quanto a aegirina-augita. A substituição é feita tanto nas bordas como nos nūcleos dos piroxênios, ou ambos ao mesmo tempo, até à substituição total (Microfó tografia $7,9,10,11,12,13)$.

Em diversos anfibólios, principalmente na parte externa do maciço, são verificadas bordas com cores azuladas, le vemente pleocröicas. Nos cristais onde ocorre o fenōmeno parece haver um zoneamento mais ou menos homogèneo, onde no centro tem- se hornblenda normal e à medida que se afasta do centro a colo ração do anfibölio passa gradativamente para cores azuladas. Podem ainda ocorrer, pequenos cristais completamente azulados onde não se verifica zoneamento nenhum. Trata-se provavelmente de um anfibólio sódico afim da arfvedsonita,possivelmente eckermanita. Faltam outros dados, de natureza especialmente química, para se confirmar a identificação. 
E interessante ressaltar que tanto na parte inter na como na parte externa ocorrem rochas onde não se verifica a ocorrência de anfibólios, inclusive o afloramento portador de ne felina $(A-115)$. No momento não temos como explicar o fenômeno.

O grau de fraturamento dos anfibölios é bem menor que nos piroxênios. Os anfibōlios são mais resistentes à decompo sição que os piroxênios, sendo dificil a sua alteração que quando ocorre, manifesta-se por preenchimento das linhas de clivagem por hidrōxido de ferro, com raras bordas de alteração a clorita.

\section{- Biotita}

E o mineral, entre os mäficos, que apresenta maior variação de tamanho, desde lamelas submicroscōpicas atē a cerca de $1 \mathrm{~cm}$. São anhedrais a subhedrais, com pleocroismo marrom aver melhado bem evidente, clivagem segundo (001), podendo apresentar extinção pouco ondulante indicando pequena deformação, quando ou após sua cristalização.Dos minerais mäficos e o que melhor obede ce à orientação fluidal (Microfotografia 14), mas não se trata de regra geral. Ocorre sempre intercalado ou associado aos piroxênios e/ou anfibōlios, com distribuição homogênea na rocha. Nos piroxênios, a biotita se desenvolve ao longo dos planos de cliva gem, desde cristais pontuais atē cristais com dimensões milimé tricas. Tal relação evidencia sua idade mais nova. 0 mesmo fenômeno é observado nas bordas dos piroxēnios. (Microfotografias 4, $8,13)$.

Nos anfibölios a associação com a biotita se faz principalmente nas bordas, tambëm com formas de corrosão, mas não tão bem desenvolvidas como nos piroxênios, o que indica ser a biotita mais nova que os anfibólios (Microfotografias $8,12,13$ ).

A biotita pode ter em seu interior halos pleocrōi cos, originados provavelmente por fenómenos de radiação a partir dos microcristais de zircão ou ainda titanita. Apresenta-se um pouco alterada, e quando isto acontece as bordas são cloritiza das. 


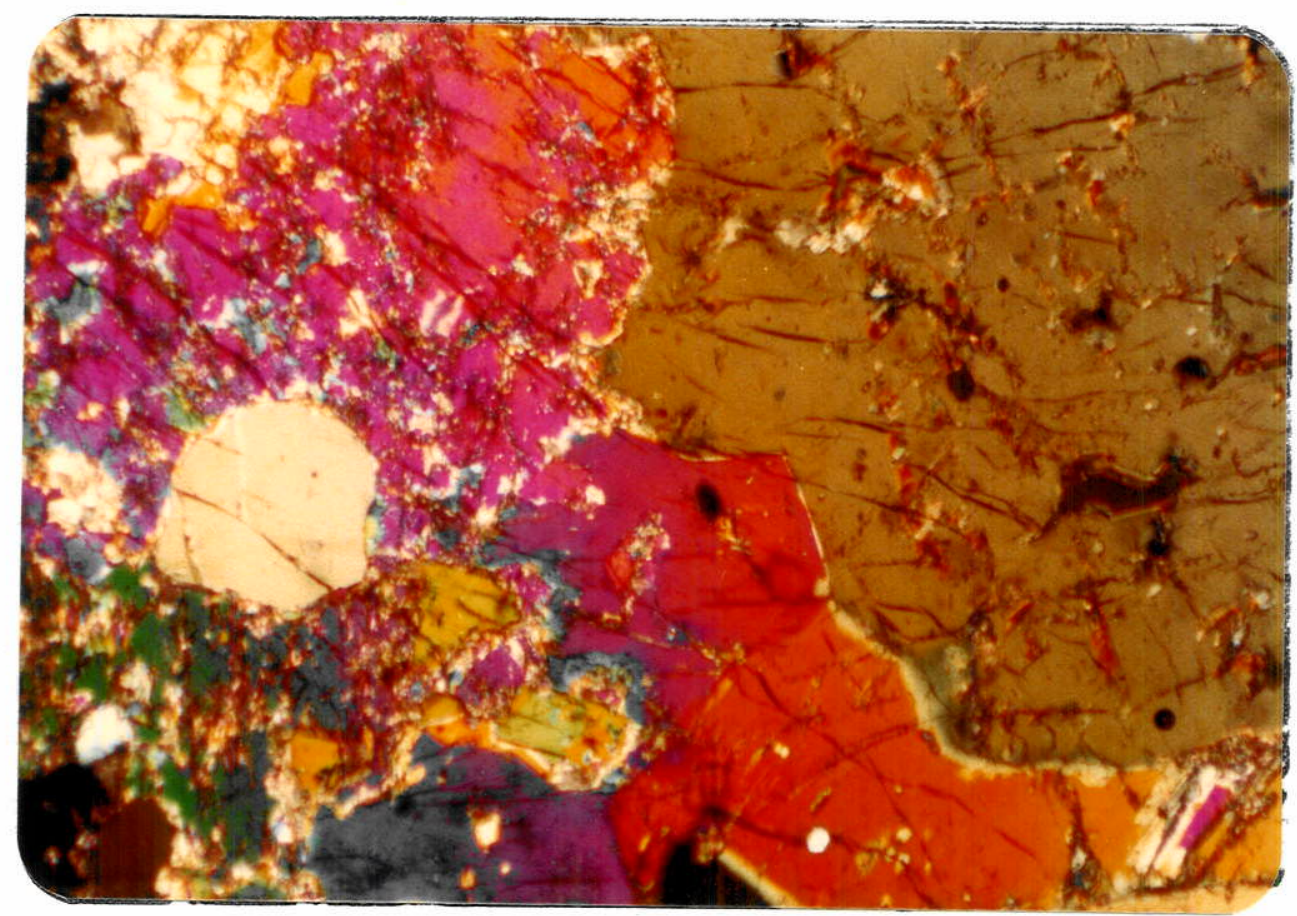

Microfotografia 13 - Contato de corrosão entre piroxênio e anfibólio (cor verde) sendo que ambos mostram inīcio de substituição por biotita.Nicóis $x$, aumento $32 x$.

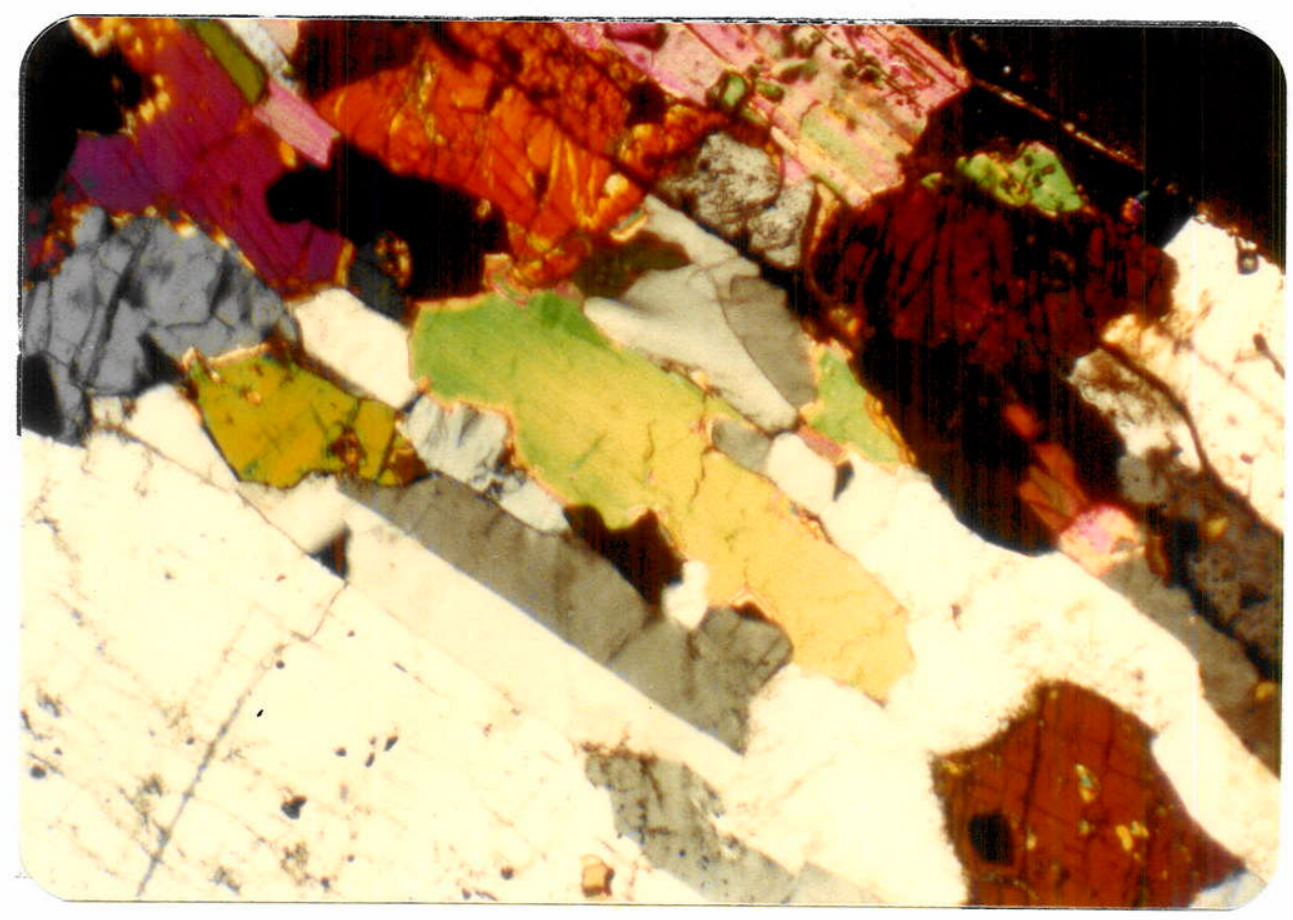

Microfotografia 14 - Sienito na qual se observa que a biotita acompanha a estrutura fluidal.Nicóis $x$, aumento $25 \times$. 
Os minerais acima descritos formam normalmente os componentes essenciais da rocha, com algumas excessões, como por exemplo quando da ausência dos anfibólios, ou quando a porcentagem volumētrica não atinge o percentual que justifique sua classificação como mineral essencial.

acessörios:

Segue abaixo uma descrição suscinta dos minerais

\section{- 01 igoclàsio}

Normalmente ocorrem sob a forma de restos, nas proximidades ou mesmo dentro dos cristais de ortoclásio. A granu lação é extremamente fina, com formas anhedrais, sendo que, pelas formas de corrosão são nitidamente englobados pelos feldspatos potāsicos.

De acordo com os àngulos de extinção, em geminados lei da Albita, o oligoclāsio possui teor médio de $22,5 \%$ de anortita.

E frequente a ocorrência de mirmequita, resultante do intercrescimento de quartzo no oligocläsio, formando textu ra tipica.

A sericita e a calcita são os principais produtos de alteração destes plagioclásios.

\section{- Quartzo}

ocorre sob a forma de pequenos cristais isolados e/ou agregados, quase sempre associados ao plagiocläsio ou inter crescidos neste sob a forma de mirmequita, entre os cristais maiores de ortociásio. Suas formas são totalmente irregulares, e mostram extinção fracamente ondulante, provavelmente devido aos esforços de penetração do material magmätico.

o quartzo ocorre somente na parte interna do macj ço sienitico. 


\section{- Apatita, Titanita e Zircão}

São acessōrios que ocorrem normalmente isolados ou ainda como inclusões nos minerais essenciais. A distribuição $\bar{e}$ homogēnea na rocha, não existindo uma associação preferencial destes minerais à exceção da titanita, que normalmente ocorre junto aos anfibólios ou piroxênios. A apatita e o zircão, em grãos isolados, ostentam formas arredondadas, anhedrais com pouca variação de tamanhos, sendo que as bordas do zircão normalmen te são de coloração escura.A titanita jā apresenta uma variação maior de tamanhos, formando cristais anhedrais e subhedrais com formas lozangulares basais mais ou menos desenvolvidas, ocorrendo de preferéncia na zona externa do maciço sienitico (tabelas 1 e 2).

\section{- Opacos}

Com formas anhedrais e subhedrais de granulação fina os opacos normalmente ocorrem associados a outros mäficos constituintes do sienito, raramente em grãos isolados dentro ou entre cristais de feldspato potássico. Quando semi decompostos e videnciam infiltração de hidróxido de ferro em minerais circunvi zinhos. A partir de teste com imã no pó da rocha, foi identifica do o mineral magnetita.

\section{- Nefelina}

Detectado num ūnico afloramento $(A-115)$. Apresen ta baixa birrefringência, uniaxial negativo, cristais anhedrais com bordas irregulares. Associada à nefelina, quando não isolada (Microfotografia 15), ocorre uma "massa" fibrosa, aparentemente mal cristalizada e acicular, birrefringência um pouco maior que os feldspatos potāssicos e não identificāvel ao microscópio. A nefelina e a "massa" sempre ocorrem entre os cristais de ortoclá sio.

Para confirmar a ocorrência de nefelina no sieni to, foram confeccionadas mais duas secções delgadas, a partir de rochas de pontos distintos nas imediações do mesmo afloramento. 


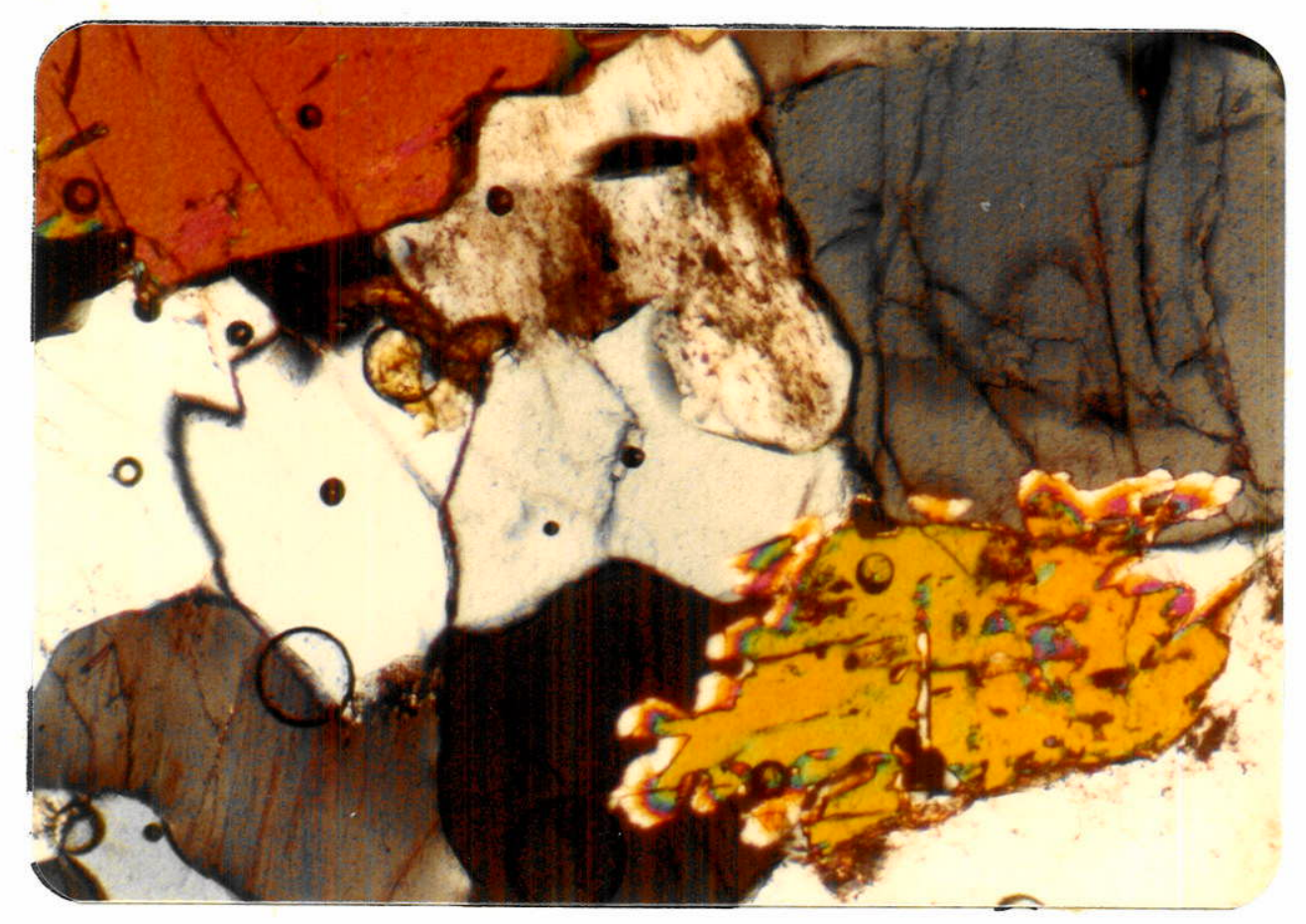

Microfotografia 15 - Nefelina (no centro) associada à ortoclásio, apatita e aegirina-augita. Nicóis $x$, aumento $32 \times$.

\section{V.4.3 - Xenōlitos que Ocorrem no Maciço Sienïtico}

\section{V.4.3.1 - Descrição Macroscópica}

Dois tipos de xenólitos foram observados no maciço, sendo um do tipo "schlieren" com contatos mais ou menos difusos, rico de biotita, com sucessivo empobrecimento deste mineral à medida que se afasta do centro do "xenórito". (Fotografia 4) 0 outro tipo tem contatos muito bem definidos, essencialmente composto por piroxénios sendo que os tabletes de ortociásio do sieni to acompanham o contorno externo do "xenólito".

\section{V.4.3.2 - Descrição Microscópica}

Microscopicamente os "xenólitos" do tipo "schlieren" são de estrutura maciça, textura hipidiomōrfica, equigranular fina a média, composta essencialmente de plagioclásio, biotita e opacos (ou espinēlio). Aparentemente são produtos de recristalização. Foram estudados os xenólitos dos afloramentos A-l7l e 
A-260. (Microfotografia 16).

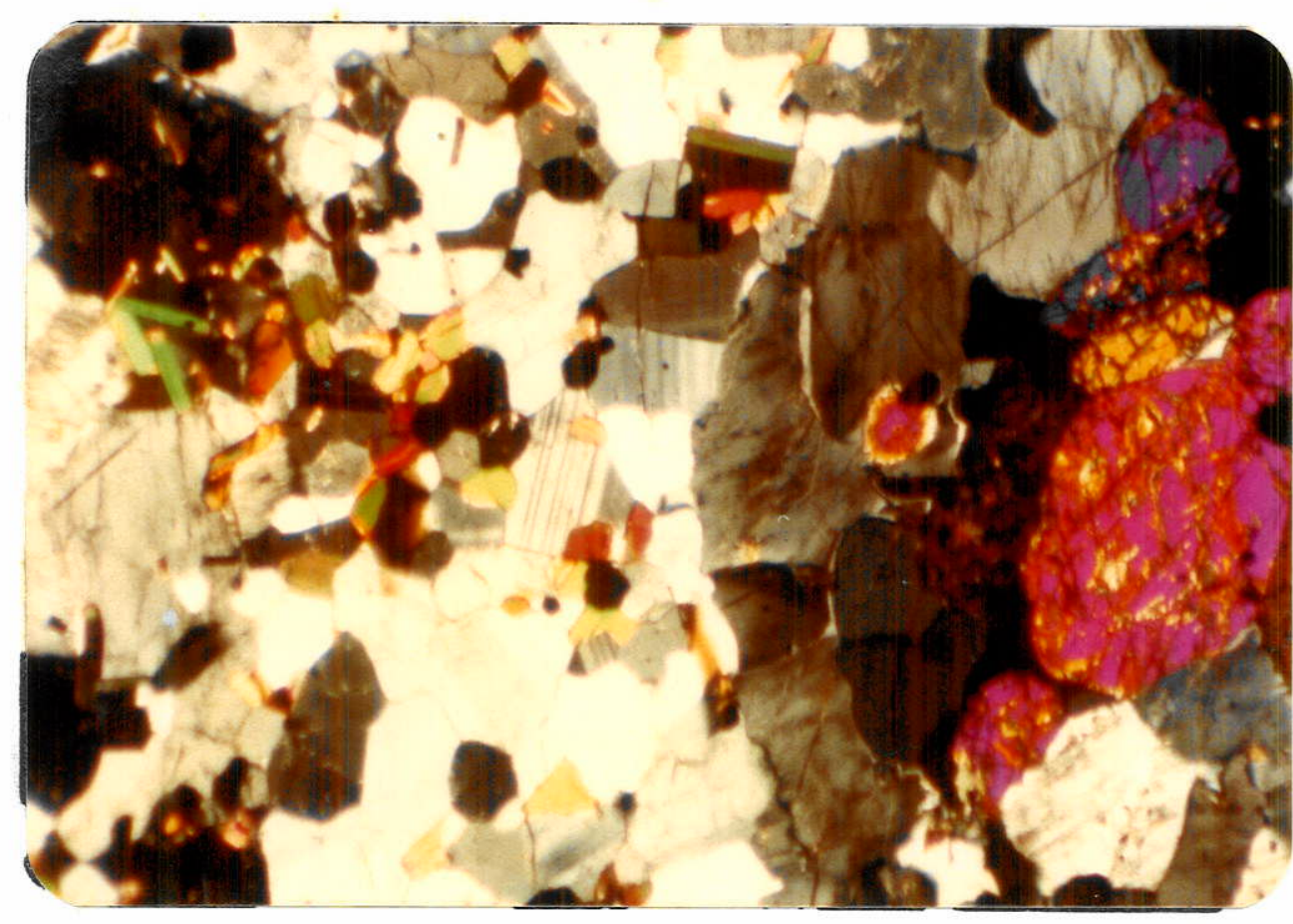

Microfotografia 16 - Afloramento A-171. "Xenólito" do tipo "schli eren" composto de plagioclásio, biotita e espinēitio (grãos pequenos, extintos). Nicóis $x$, aumento $25 \times$.

\section{- Plagioclásio}

Grãos equigranulares, euhedrais e subhedrais, ostentando geminação albita e periclina muito bem desenvolvidas. 0 teor de $42 \%$ em anortita, determinado pelo ângulo de extinção em indivĩduos geminados, revela que se trata de andesina. Estão leve mente alterados para sericita e mostram pequenas inclusões de biō tita e opacos.

\section{- Biotita}

Também formam grãos equigranulares sem direção definida, euhedrais a subhedrais. o pleocroismo é branco amareladomarrom avermelhado. Os contatos da biotita com os plagioclásios e opacos são por justaposição, com exceção das finas inclusões nos plagioclásios. As biotitas estão levemente cloritizadas nas bor- 
das.

\section{- Opacos}

São cristais anhedrais de contornos irregulares, de granulação pouco inferior aos acima citados. Ocorrem normalmente entre os plagiocläsios e a biotita com distribuição homogênea. Na amostra do afloramento A-171 em lugar de magnetita ocorre espinëlio verde, com granulação tambëm inferior em relação à biotita e andesina (Microfotografia 16). Trata-se provavelmente de hercinita. Ocorre numa proporção maior no centro do xenóli to, sendo que na região do contato sua ausência é quase total.

\section{- Acessörios}

Acessoriamente os xenōlitos ostentam cristais fi nissimos de apatita, titanita e zircão. Todos anhedrais e ocorrem homogeneamente na rocha entre os minerais essenciais.

0 segundo tipo de "xenōlito" com contatos muito bem definidos com as rochas sieniticas è de estrutura maciça, equigranular de granulação mëdia a grossa, subhedrais e anhedrais, composto quase que exclusivamente por piroxênios (aegirina-augita). Aparentemente este tipo de xenölito é representado por uma textura de acumulação de aegirina-augita e praticamente todos ocorrem justapostos, não apresentando nenhuma orientação preferen cial. (Microfotografias 17 e 18). Acessoriamente observa-se cris tais menores representados, em ordem decrescente, por apatita, tita nita, biotita e ortoclásio. Todos estes ocorrem entre os cristais de piroxênios com excessão da biotita que em alguns casos parece substituir o piroxênio. Microscopicamente neste tipo de xenōito também se observa o amoldamento dos ortoclásios ao contorno externo ovalado.

\section{V.4.4 - Diques Pegmatiticos no Maciço da Pedra Branca}

\section{V.4.4.1 - Descrição Macroscōpica}




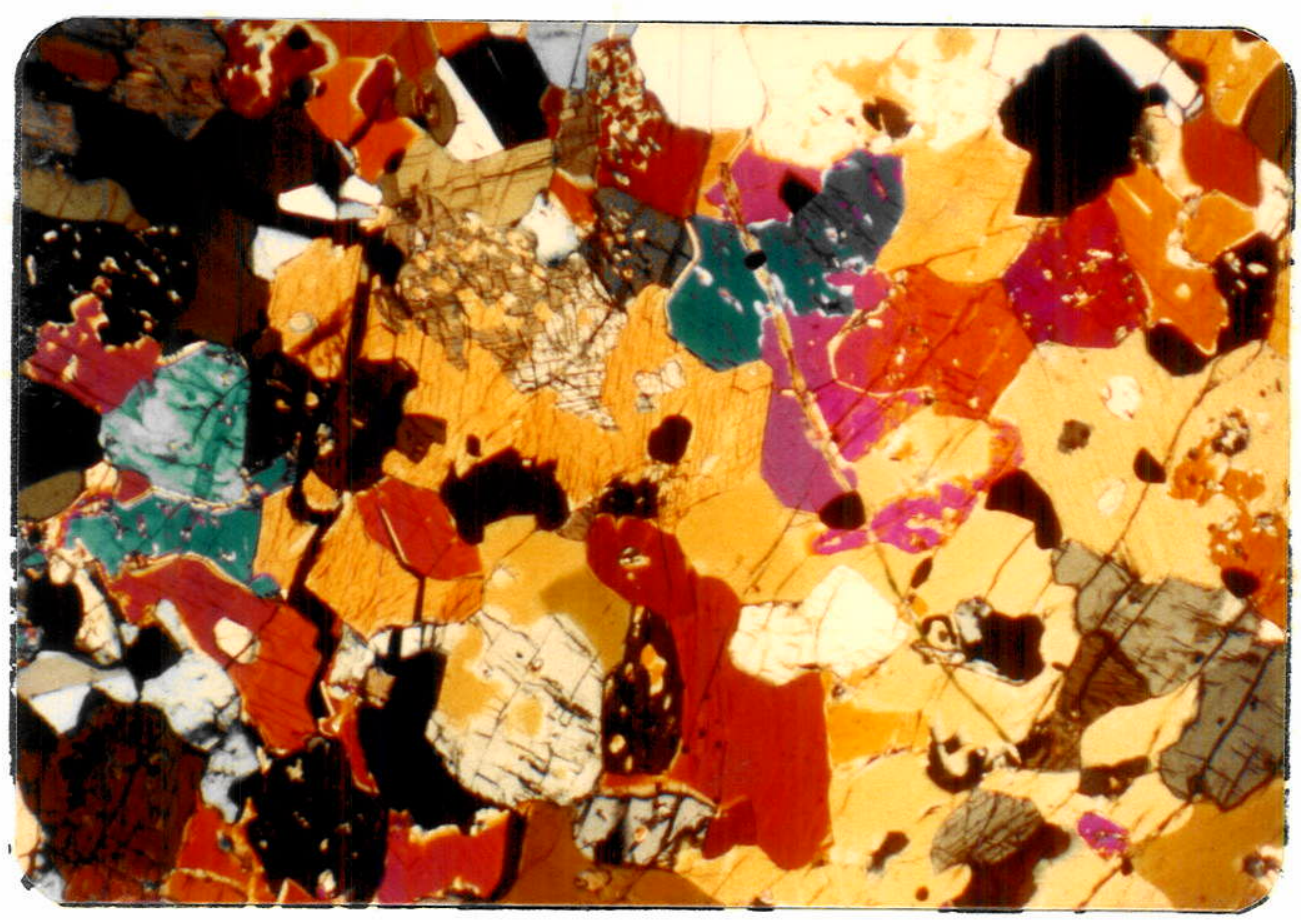

Microfotografia 17 - "Xenólito" composto quase que exclusivamente por aegirina-augita. Nicóis $x$, aumento $25 x$.

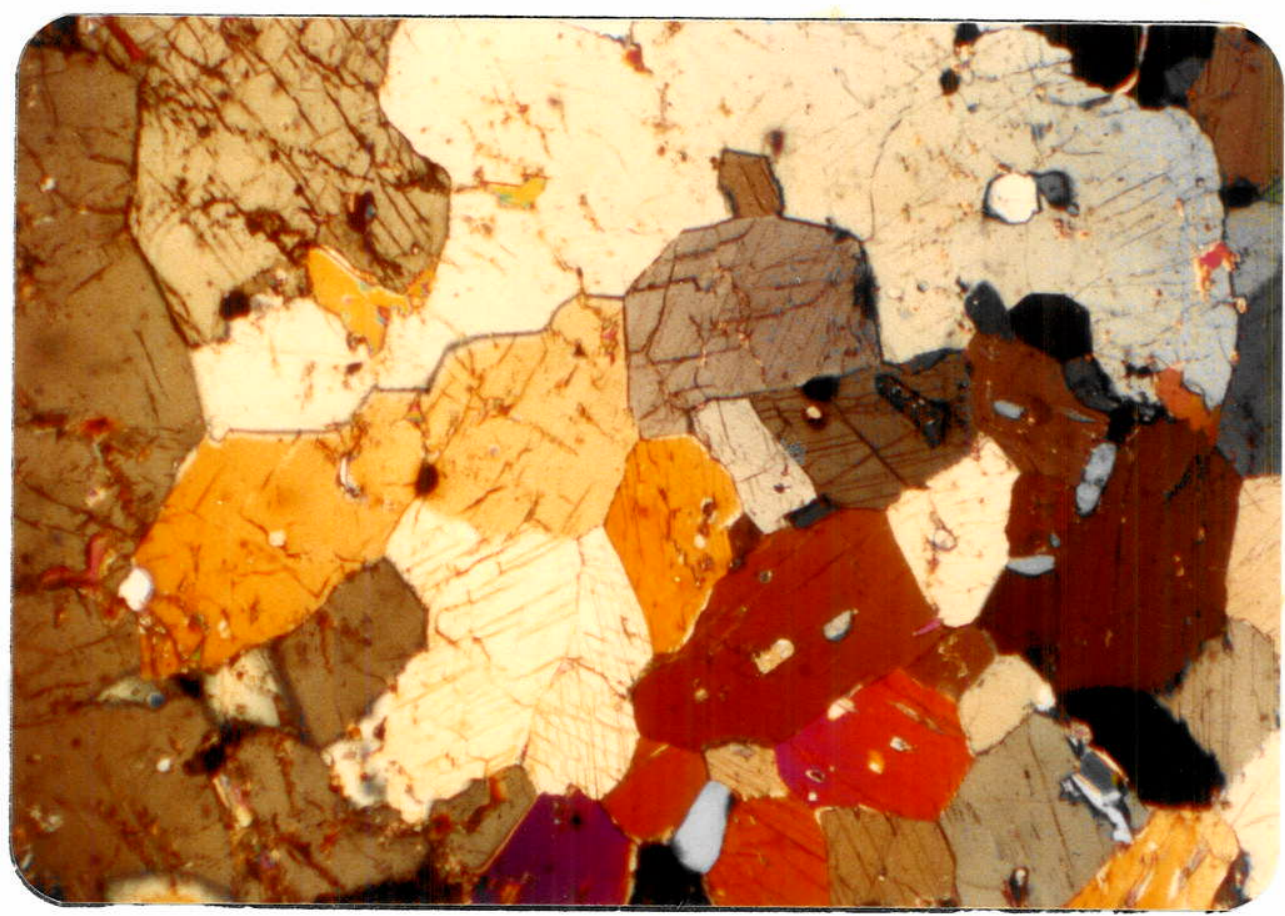

Microfotografia 18 - Detalhe da microfotografia 14, mostrando tex tura adcumulática dos piroxênios. Nicóis $x$, aumento $32 x$. 
Tratam-se de rochas maciças, com textura granular grossa a muito grossa, compostos essencialmente de feldspato potássico, quartzo e piroxēnio. Nos contatos, devido ao resfriamento rápido a granulação é bem mais fina que nas partes centrais.

Estes diques devem estar associados à fase final de cristalização dos sienitos, fase esta normalmente rica em soluções voláteis.

\section{V.4.4.2 - Descrição Microscōpica}

A estrutura e a textura ao microscōpio são idênticas às descritas macroscopicamente. Quanto à mineralogia são observadas as mesmas associações do corpo de sienito, em sua par te interna, ou seja, na zona supersaturada. A única diferença ré almente marcante é a granulação e a porcentagem maior em quartzo.

\section{- Ortociásio}

Apresenta as mesmas características dos feldspa tos da zona interna do maciço, isto é: o mesmo tipo de geminação; intercrescimento pertîtico apresentando tambēm, as finissimas in clusões sob a forma de "agulhas" e "pingos".

\section{- Quartzo}

E de ocorréncia bastante superior aos sienitos su persaturados ( 15 a $20 \%$ ), com bordas irregulares, anhedrais, com extinção fracamente ondulante. Ocorre entre os cristais de ortoclāsio e sempre associado a oligoclásio ou intercrescido com es te, sob a forma de mirmequita.

\section{- Diopsidio}

Tambēm de ocorrência semelhante aos sienitos da zona interna, sem orientação nenhuma, sendo substituido por hor $\underline{n}$ 
blenda e biotita.

\section{- Acessörios}

Como acessōios tem-se; hornblenda, biotita,opacos, titanita e apatita com todas as caracteristicas de ocorrēn cia semelhantes à zona interna supersaturada do maciço sienitico.

\section{V.5 - Rochas Sedimentares}

\section{V.5.1 - Descrição Macroscōpica}

Como já descrito no capitulo da geologia local, as rochas desta unidade são compostas essencialmente por arenitos, constituĩdos por grãos de quartzo na sua maioria numa matriz bastante alterada de composição quartzo feldspática.A rocha quando sã apresenta coloração acinzentada, variāvel quando decomposta, passando de cores esbranquiçadas até amareladas. Apresenta uma granulação muito fina. Sua estrutura ē maciça, sen do que o intemperismo superficial destaca, na mesma, as feições do acamamento original.

\section{V.5.2 - Descrição Microscōpica}

Os arenitos são essencialmente constituídos por grãos de quartzo, granulação muito fina, medianamente seleciona dos, angulosos com baixa esfericidade, sem orientação nitida. A granulometria estā compreendida dentro da classe areia fina.Não se observam minerais mäficos mas somente opacos, totalmente sem forma, preenchendo algumas fraturas. Ocorrem raros grãos de zircão com distribuição caōtica na rocha. A matriz è constituĩ da por um material argiloso, provavelmente gerado da alteração de feldspatos, e contēm fragmentos diminutos de quartzo. A rocha apresenta textura reliquiar de um provävel arenito fino,sen do que devido às características micro e macroscópicas observadas, bem como à sua localização no campo,junto ao contato com 
as intrusivas do Maciço Alcalino de Poços de Caldas, parece ter sofrido um metamorfismo de contato de baixo grau.

\section{V.6 - Rochas do Maciço Alcalino de Poços de Caldas}

Serä feita uma descrição resumida das litolo gias que compõem o Maciço Alcalino de Poços de Caldas na ärea mapeada, jā que não foi feita petrografia de detalhe.

\section{V.6.1 - Tinguaitos}

\section{V.6.1.1 - Descrição Macroscōpica}

Trata-se de rochas maciças, afanticas e subafa niticas, mesocráticas, com aspectos porfiriticos caracterizada atravēs de feno cristais de feldspato potässico e/ou piroxênio dispersos em massa afanitica. A coloração dos tinguaitos é preta esverdeada. Quando alterados os tinguaitos mostram diversos estāgios de bauxitização. A Norte de Andradas estas rochas apresentam uma ligeira estrutura fluidal lembrando lavas consolidadas, do que se infere tratar-se provavelmente de fonölitos.

\section{V.6.1.2 - Descrição Microscöpica}

Microscopicamente os tinguaitos confirmam sua estrutura porfiritica podendo apresentar fenocristais euhedrais de sanidina e aegirina ou somente fenocristais de sanidina ou ainda somente fenocristais de aegirina. Estes cristais, às vezes mostram-se zonados com núcleos menos sōdicos. A matriz dos fenocristais é extremamente fina composta por pequenos cristais de sanidina e pequenos prismas de aegirina. A disposição radiada dos minerais na massa às vezes ē observada tanto por parte dos feldspatos como dos piroxentios. Acessoriamente ocorrem opa$\cos$ (provavelmente magnetita), nefelina e aegirina-augita. Os opacos quase sempre estão associados aos piroxênios. A nefelina e aeģirina tem distribuição caótica na rocha. 


\section{V.6.2 - Nefelina Sienitos}

\section{V.6.2.1 - Descrição Macroscōpica}

Apresentam-se com coloração cinza claro a escuro e apōs sofrerem alteração exibem uma crosta esbranquiçada de provāvel composição bauxîtica. A estrutura ē maciça. A textura é equigranular com granulação fina, portando raros cristais de feldspato potássico de granulação média. Fica difícil a identifi cação de outros minerais.

\section{V.6.2.2 - Descricão Microscöpica}

São rochas de estrutura e textura maciças consti tuidas essencialmente de sanidina que se apresenta sob a forma de cristais alongados, raramente exibindo geminação carlsbad.Como minerais essenciais ainda temos: nefelina, tanto com formas anhedrais como subhedrais, associadas por justaposição ou dentro dos cristais de sanidina; analcita, que ostenta granulação varia vel, em cristais que devido a sua forma cristalogräfica, no passado, possivelmente formaram cristais de nefelina; aegirina, com cristais irregulares a regulares, prismäticos, com granulação va riāvel, regularmente distribuỉdos na rocha, sem associação ou orientação preferencial. A magnetita e a calcita ocorrem acessoriamente sendo o primeiro normalmente associado à aegirina, com alguns grãos parcialmente limonitizados. A calcita ocorre em for ma muito irregular, geralmente associada ou inclusa na sanidina.

\section{V.6.3 - Bostonitos}

\section{V.6.3.1 - Descrição Macroscōpica}

De uma maneira geral estas rochas se apresentam semi decompostas a totalmente decompostas com coloração cinza a marelada, granulação muito fina a afanitica, pigmentadas por mi nüsculas pontuações em sua maioria esbranquiçadas, o que lhes confere à primeira vista o aspecto de um arenito arcosiano fi- 
no, cimentado. Nas partes mais alteradas, a rocha se apresenta com uma camada amareio esbranquiçada, de aspecto poroso, sem quar tzo. Em vista do posicionamento de campo e das observações acima, tratar-se-ia de uma rocha alcalina efusiva. Embora a estrutu ra seja maciça o cerrado sistema de fraturas, em alguns aflora mentos, confere à rocha um aspecto brechoide, muito bem ressaltado pelo intemperismo. Não é possivel a identificação macroscópica de qualquer constituinte mineral.

\section{V.6.3.2 - Descrição Microscöpica}

Trata-se de rochas essencialmente constituidas por sanidina, em cristais totalmente irregulares e intercresci dos, sem orientação determinada. Em certas partes da rocha os cristais exibem crescimento radiado, aparentando glóbulos.0 sistema de microfraturas acha-se preenchido por material limonitico resultante da decomposição de opacos que ocorrem dispersos na rocha como mineral acessório. Raros são pequenos cristais de aegirina, totalmente decompostos e zircão. 
Os estudos geocronológicos foram efetuados atravēs da utilização dos métodos K-Ar e Rb-Sr. Pelo método K-Ar foram feitas três determinações em minerais isolados de uma mesma amostra e treze determinações atravēs do emprego do método 品Sr, selecionadas das vinte e sete amostras submetidas a anālise semiquantitativa prēvia de Rb e Sr. Os dados analiticos podem ser observados respectivamente nas tabelas 3 e 4 . A localização das amostras datadas são indicadas no mapa de pontos geológicos estudados em anexo.

$\mathrm{Na}$ determinação $\mathrm{K}-\mathrm{Ar}$ foram analisadas individual mente a hornblenda, biotita e ortociásio por serem favoräveis à retenção de argōnio. Os resultados devem ser interpretados como valores mînimos indicativos da época de resfriamento regional pa ra cada mineral analisado e "fechamento do reticulo cristalino do mineral". Deve ser ressaltado que mesmo à temperatura ambiente ainda ocorre o escape de argónio nos ortoclásios.

Pelo método Rb-Sr foram analisadas em rocha tota1, cinco amostras de granito, sete amostras de sienito e uma amostra de tinguaitos do Maciço Alcalino de Poços de Caldas. A discussão dos resultados atravēs deste método só foi possivel pa ra as rochas granīticas mediante interpretação do grāfico isocrô nico $\mathrm{Rb}^{87} / \mathrm{Sr}^{86}$ em relação a $\mathrm{Sr}^{87} / \mathrm{Sr}^{86}$. Os sienitos mostraram-se desfavorāveis ao método pelo alto teor em $S r(2185$ até 3945 ppm) em relação ao Rb (no máximo $197 \mathrm{ppm}$ ). O mesmo fenômeno ocarre com os tinguaitos.

O objetivo das anälises K-Ar foi o de determinar a real idade de resfriamento dos minerais brasilianos, verificar se houve fenomenos de metassomatismo por fenitização e abertura do sistema para o escape de argônio durante a intrusão do Maciço Alcalino de Poços de Caldas além de "checar" os dados $\mathrm{Rb} / \mathrm{Sr}$.

Nas determinações $\mathrm{Rb} / \mathrm{Sr}$ em rocha total o objetivo foi o de determinar a idade de formação das rochas, jā que 
se trata de rochas igneas. Entretanto a proporção Rb-Sr desfavorävel, impediu a obtenção de resultados representativos para as rochas sieniticas.

Lamentavelmente os dados geocronológicos são em nümero bastante reduzido devido à sobrecarga do Centro de pesqui sas Geocronolögicas quando da execução das anālises aqui apresen tadas.

\section{VI.1 - Mëtodo K-Ar}

Nas três determinações realizadas a partir de ro chas do afloramento $\mathrm{Cd}-125$ (tabela 3 ), correlacionāveis à idade de resfriamento desses minerais, é curiosa a diferença de idade apresentada pela hornblenda, de $899,09 \pm 76,83 \mathrm{~m} . \mathrm{a}$. em relação à da biotita; $631,38 \pm 18,05 \mathrm{~m} . \mathrm{a}$. e ortoclásio; 583,51 $\pm 32,39$ m.a..Se se considerar suas origens por cristalização magmática, mesmo sabendo-se que a diferença de temperatura para a retenção de argônio dos anfibölios em relação as biotitas è de $250^{\circ}$. 0 intervalo de 174 a $352 \mathrm{~m}$.a. entre a cristalização do anfibōlio e da biotita pode indicar que a hornblenda pertenceria a um even to tectónico prë-Brasiliano, guardando parcialmente seu argōnio. A se confirmar a premissa o sienito seria produto de fusão parcial de rochas pré-existentes.

Poderiamos supor tambēm, uma possivel cristaliza ção magmática a partir de um "mush" de cristais formados em gran des profundidades, com uma grande diferença de tempo entre a cristalização da hornblenda e a biotita. A ültima hipótese parece ser mais viāvel apesar de se desconhecer qualquer dado biblio gräfico sobre fenomenos semelhantes.

As idades reveladas pela biotita e o ortoclásio indicam que são perfeitamente vinculāveis aos eventos do cicro Brasiliano.

E necessärio ressaltar que o nümero de anālises feitas é muito pequeno para realmente informar sobre as ëpocas de resfriamento destes sienitos. Para o esclarecimento definiti- 
TABELA 3 - RESULTADOS DAS DETERMINAÇOES K-Ar

Nọ Laboratōrio

SPK

3513

3514

3526
Nọ de Campo

cd -125

$C d-125_{3}$

$C d-125$
Material

Anfibölio

Feldspato Potāssico

Biotita
Rocha

Hornblenda Sienito

Hornblenda Sienito

Hornblenda Sienito dade (Milhões de anos)

$$
\begin{aligned}
& 899,09 \pm 76,83 \\
& 583,51 \pm 32,39 \\
& 631,38 \pm 18,05
\end{aligned}
$$


vo da questão, torna-se indispensāvel no futuro, um maior número de dados K-Ar uma vez que o método Rb/Sr è totalmente desfavorāvel. Não obstante, os dados de campo, estruturais e petrogräfi cos realmente indicam serem os sienitos intrusivos em granitos de idade Brasiliana.

As idades aparentes da biotita e ortocläsioguar dariam relação com vārias gerações de granitóides constituintes do Grupo Pinhal (Wernick e Penalva, 1980). Os dados K-Ar da biotita e ortoclásio dos sienitos tambēm entram em concordância com trabalhos realizados no Sistema de Dobramentos Ribeira e Zona Cristalina Norte de São Paulo (Cordani e Bittencourt, 1967 ;Ebert e Brochini, 1968; Vandoros e Franco, 1969; Cordani e Kawashita, 1971; Hasui e Hama, 1972; Cordani et a1., 1973 e 1974; Wernick et al., 1976b; Wernick e Penalva, 1978).

\section{$V I .2$ - Mētodo Rb/Sr}

Dado que os sienitos e tinguaitos mostraram desfavorabilidade ao método pelo alto teor em $\mathrm{Sr}$ em relação ao Rb, foi possivel obter uma isócrona somente a partir das rochas granitticas. As idades convencionais Rb-Sr destes granitos são encon tradas na tabela 4, todas calculadas, empregando-se a razão inicial de 0,7080 o que implica considerarmos estes granitos vinculados entre si, a partir de um mesmo processo genético ou fonte magmätica.

A figura 5 mostra a isōcrona obtida em amostras de granitos equigranulares, representados pelos afloramentos A106 (amostras a,b,e), A-164 (amostra c) e uma amostra de granito porfiróide representada pelo afloramento A-92. As localizações dos afloramentos encontram-se, no mapa de pontos anexo.

A isōcrona de referência da figura 5 , por seu pequeno desvio padrão, indica uma homogeneização isotópica ocorrida a $570 \pm 6 \mathrm{m.a}$., caracteristica da fase final do Ciclo Brasi liano, como jā descrito anteriormente no método K-Ar. Pela razão inicial $\mathrm{Sr}^{87} / \mathrm{Sr}^{86}$ de 0,711 , relativamente alta, pode-se sugerir que o material granitico resultou de processos de remobilização 
TABELA 4 - VALORES DE RAZAO INICIAL PARA ROCHAS DA AREA DA PEDRA BRANCA

\begin{tabular}{|c|c|c|c|c|c|c|c|c|c|}
\hline $\begin{array}{l}\text { No de } \\
\text { Campo }\end{array}$ & Material & Rocha & $\begin{array}{c}\text { No Lab } \\
\text { (SPR) }\end{array}$ & $\begin{array}{c}\text { Rb Total } \\
(p p m)\end{array}$ & $\begin{array}{c}\text { Sr Total } \\
(p p m)\end{array}$ & $\begin{array}{c}S r^{87} / s r^{86} \\
\pm 15 \%\end{array}$ & $\begin{array}{c}\mathrm{Rb}^{87} / \mathrm{Sr}^{86} \\
\pm \quad 3 \%\end{array}$ & $Y_{0}$ Admitido $=$ & Idade Convencional \\
\hline$A-92$ & Rocha Total & $\begin{array}{l}\text { Granito } \\
\text { Porfirōide }\end{array}$ & 1861 & 152,0 & 496,5 & 0,7190 & 0,9800 & 0,7080 & $838,4 \pm 163 \mathrm{~m} \cdot \mathrm{a}$ \\
\hline$A-106 a$ & Rocha Total & Granito & 1863 & 247,3 & 211,9 & 0,7403 & 3,3900 & 0,7080 & $646,0 \pm 45,2 \mathrm{~m} \cdot \mathrm{a}$ \\
\hline A $164 \mathrm{c}$ & Rocha Total & Granito & 1862 & 348,8 & 61,5 & 0,8505 & 16,6500 & 0,7080 & $579,7 \pm 14,5 \mathrm{~m} \cdot \mathrm{a}$ \\
\hline$A-106_{b}$ & Rocha Total & Granito & 1864 & 210,6 & 248,5 & 0,7291 & 2,1500 & 0,7080 & $666,5 \pm 66,7 \mathrm{~m} \cdot \mathrm{a}$ \\
\hline$A-106 e$ & Rocha Total & Granito & 1865 & 226,5 & 225,4 & 0,7356 & 2,9200 & 0,7080 & $639,9 \pm 49,0 \mathrm{~m} \cdot \mathrm{a}$ \\
\hline$A-238$ & Rocha Total & Tinguaito & 1866 & 156,4 & 1717,5 & 0,7070 & 0,2600 & 0,7050 & \\
\hline$c_{d}-125 c$ & Rocha Total & Sienito & 1869 & 185,8 & 2440,0 & 0,7105 & 0,2201 & 0,7070 & \\
\hline$C d-125 b$ & Rocha Total & Sienito & 1868 & 143,2 & 3945,0 & 0,7081 & 0,1051 & 0,7070 & \\
\hline$A-260 a$ & Rocha Total & Sienito & 1867 & 154,2 & 2463,0 & 0,7098 & 0,1810 & 0,7070 & \\
\hline$A-250 b$ & Rocha Total & Sienito & 2068 & 186,2 & 2378,6 & 0,7091 & 0,2270 & 0,7070 & \\
\hline$A-291 d$ & Rocha Total & Sienito & 2069 & 197,1 & 2569,3 & 0,7082 & 0,2220 & 0,7070 & \\
\hline$c d-125 e$ & Rocha Total & Sienito & 2070 & 177,4 & 2185,2 & 0,7090 & 0,2350 & 0,7070 & \\
\hline$C d-125 e$ & Rocha Total & Sienito & 2067 & 146,0 & 3737,3 & 0,7087 & 0.1100 & 0,7070 & à \\
\hline
\end{tabular}




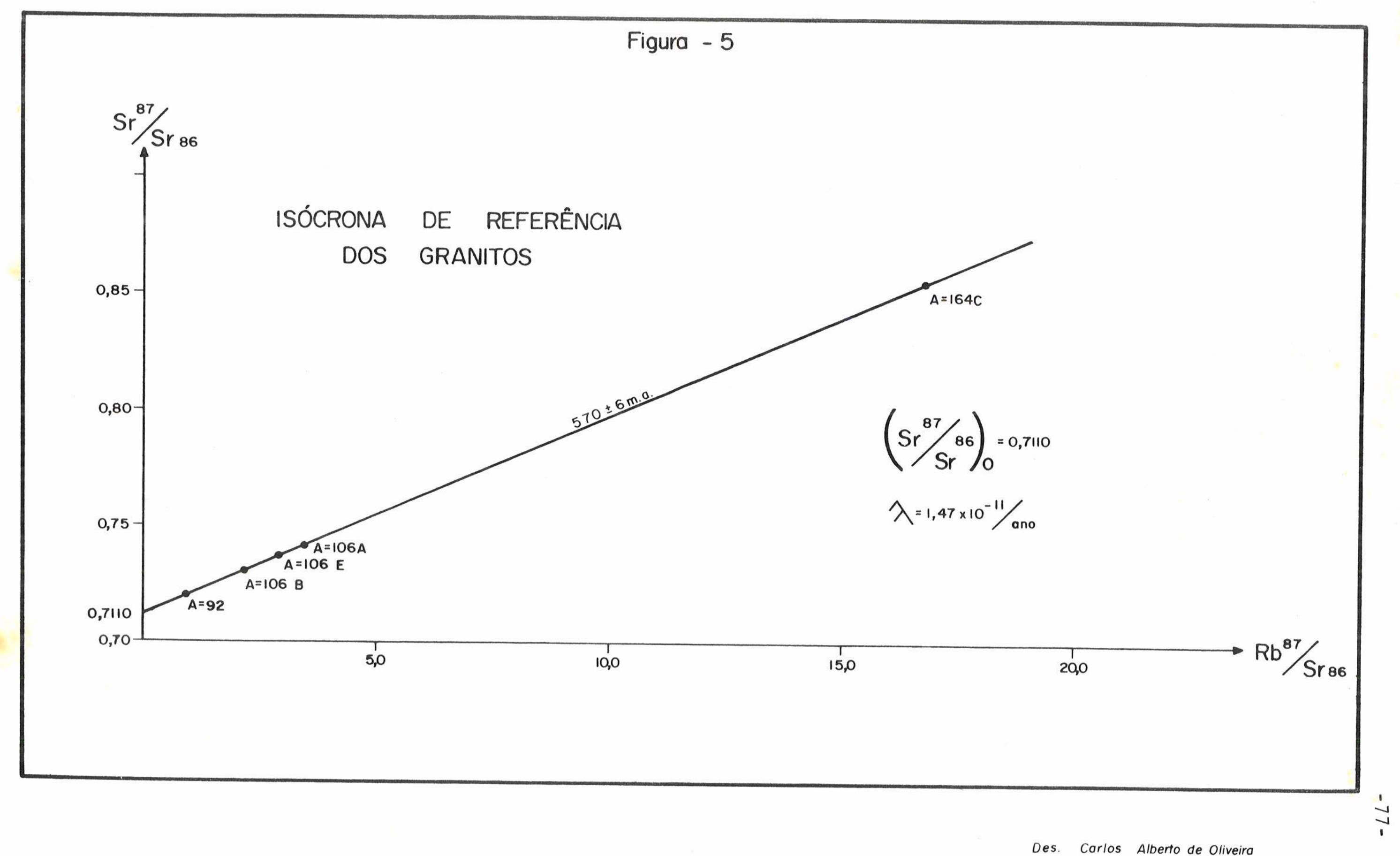

Des. Carlos Alberto de Oliveira 
e refusão da crosta, (Wernick e Gomes, 1977). A amostra A-92 re presentando um granito porfirōide, que, por suas relações de campo, $\bar{e}$ nitidamente anterior aos granitos equigranulares, tem idade convencional de $838,4 \pm 163 \mathrm{~m} . \mathrm{a}$., tratando-se pois, de uma fase precoce do Ciclo Brasiliano. A relativa frequencia de idades K-Ar entre 750 e $850 \mathrm{~m} . \mathrm{a}$. (Wernick, comunicação verbal), abre a possibilidade de que o Ciclo Brasiliano seja caracterizado por dois importantes eventos tectónicos, respectivamente com idades entre 850 e $750 \mathrm{~m}$. a. e $650 \mathrm{~m} . \mathrm{a}_{\text {. }}$ à semelhança do $\mathrm{C}$ clo Pan-Africano.

Devido ao alto teor em $S r$ nas rochas sieniticas (tabela 4), os pontos lançados na figura 6 se situam prōximos à origem, ficando a razão $\mathrm{Sr}^{87} / \mathrm{Sr}^{86}$ de cada amostra muito prōxima à razão inicial. Por serem muito ricas em $\mathrm{Sr}$, a distribuição $\mathrm{Rb}^{87} / \mathrm{Sr}^{86}$ tambēm varia pouco e com valores extremamente baixos.

Poderia se supor que as rochas sieniticas são produto de diferenciação das rochas graniticas com grande enriquecimento em $\mathrm{sr}$.

Na mesma figura 6 foi lançada a amostra A-238, representativa dos tinguaitos do Maciço Alcalino de Poços de Caldas. Como pode ser observado, apesar de toda a heterogeneida de na distribuição dos sienitos, não hä aparentemente qualquer relação temporal entre os tinguaitos e as rochas sieniticas da Pedra Branca. 
Figura - 6

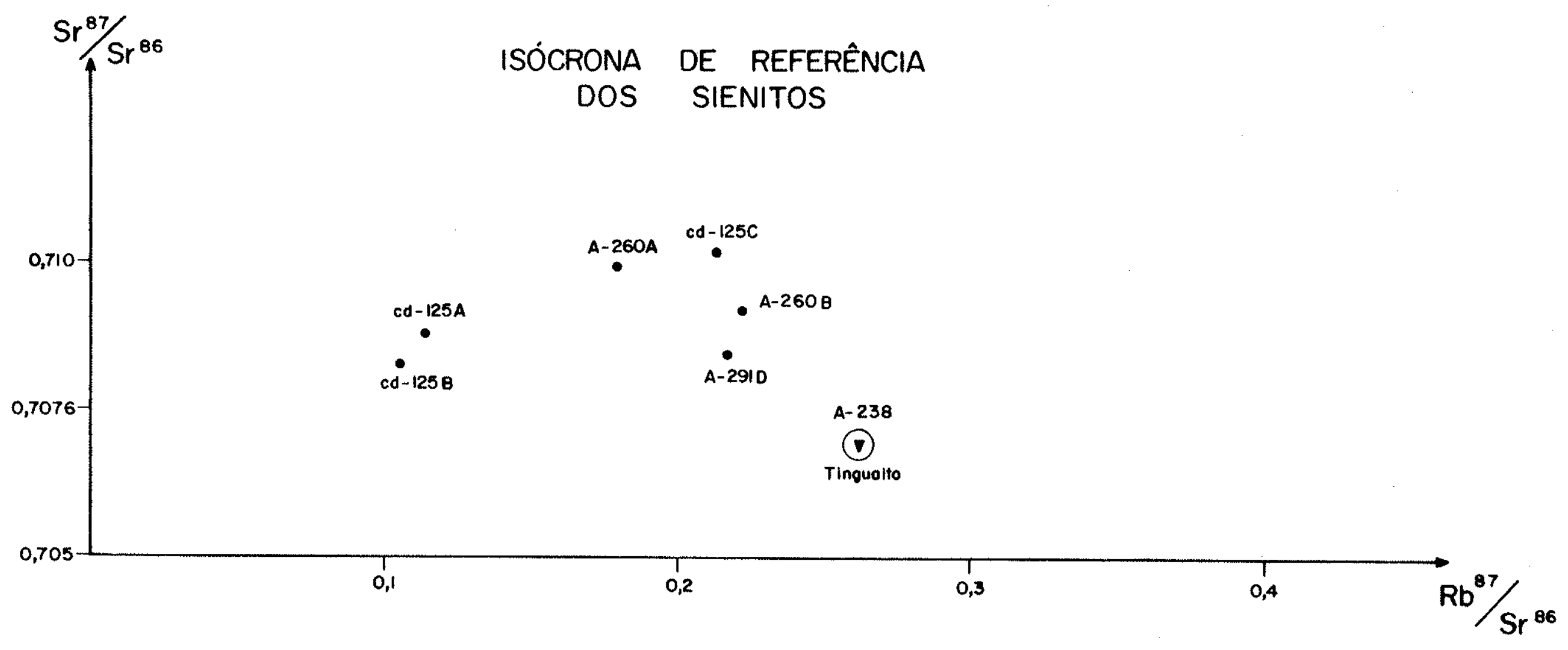

Des Carlos Alberto de Oliveiro 


\section{VII - DISCUSSAO DOS RESULTADOS}

\section{VII.1 - Evolução Geolögica LocaI}

Com base no conteūdo dos capitulos anteriores, tentaremos aqui uma breve sintese da evolução cronogeológica da ārea de Caldas, Santa Rita de Caldas, Ibitiüra de Minas e Andradas, conforme segue:

1) Formação de metassedimentos e meta igneas do Complexo Silvianópolis e/ou Grupo Amparo, correlacionāveis ao $\mathrm{Ci}$ clo Jequié ou Ciclo Transamazōnico.

2) Injeção de material granitico nas litologias a cima citadas formando migmatitos e concomitantemente a formação de granitos porfirōides cuja idade convencional Rb/Sr ē de 838,4 $\pm 163 \mathrm{m.a}$, portanto, correlacionāveis ao primeiro evento do $\mathrm{Ci}$ clo Brasiliano. Na ārea mapeada os granitos porfirōides ostentam distribuição circular.

3) Intrusão de granitos equigranulares cortando granitos porfirōides, com idade determinada atravēs de isōcrona de referência $\mathrm{Rb} / \mathrm{Sr}$ de $570 \pm 6 \mathrm{~m} . \mathrm{a}$., referível à fase pós-tectóni ca do Ciclo Brasiliano. Estes granitos, na área mapeada tambäm ocorrem com distribuição circular.

4) Intrusão de forma superficialmente circular, com $15 \mathrm{~km}$ de diāmetro, com paredes externas compondo um corpo cônico invertido, composto de sienitos ostentando estrutura planar de fluxo acompanhando a forma circular. Também é de idade Brasiliana, revelada atravēs de idades $K / A r$ de biotita e ortoclásio; $631,4 \pm 18$ e $583,5 \pm 32,4$ m.a. respectivamente. Estes sienitos apresentam-se zonados sendo a parte externa do maciço saturada a insaturada e saturada a supersaturada em $\mathrm{SiO}_{2}$ na parte central fe nômeno atribuĩvel a uma possivel cristalização por segregação mag mätica.

5) Sedimentação de arenitos correlacionăveis ao Grupo Tubarão de idade Permo-carbonifera. 
6) Formação, no Cretāceo Superior, do Maciço Alcalino de Poços de Caldas, de contorno circular. Abatimento recobrimento da parte ocidental do Maciço da Pedra Branca e granitos encaixantes por rochas vulcáncias alcalinas.

\section{VII.2 - Os Sienitos do Maciço da Pedra Branca}

Discutem-se aqui os argumentos que indicam uma origem magmātica dos sienitos antes que por fenitização, como até então postulado:

1) Os contatos externos do maciço sienītico são bruscos por efeito de penetração forçada, originando uma estrutu ra planar de fluxo, muito bem desenvolvida, que acompanha este contato, circular, externo. Em caso de fenitização este contato seria transicional.

2) As sucessivas substituições de piroxênios por anfibölios e destes por biotita, que ocorrem nestes sienitos, mais uma vez evidenciam uma cristalização magmātica normal. No caso de fenitização a cristalização metassomática seria totalmente oposta à mostrada pelos sienitos da Pedra Branca, isto é, teríamos a substituição da biotita por hornblenda e ambos seriam subs tituỉdos por piroxênios (alcalinos).

3) O zoneamento apresentado pelo maciço,com suas partes externas saturadas a insaturadas e saturadas a supersaturadas com atē $6 \%$ em $\mathrm{SiO}_{2}$ livre na sua parte interna, (contato com o Maciço Alcalino de Poços de Caldas) evidenciam mais uma vez uma cristalização magmātica para o referido maciço. Este zoneamento parece ocorrer sob a forma de transição gradual. No caso de fenitização, o zoneamento mineralógico seria inverso ao acima apresentado; haveria uma forte dessilicificação na região do contato com o maciço alcalino, com o consequente enriquecimen to em $\mathrm{SiO}_{2}$ à medida que se afasta deste contato.

4) A presença de "schlieren" e segregações no Mą ciço da Pedra Branca, denota cristalização magmätica. 
5) Embora em nümero muito reduzido, as anāilises K/Ar efetuadas em anfibólio, biotita e ortoclāsio, indicam uma cristalização de idade Brasiliana apesar da idade um pouco elevada do anfibōlio; com certeza o sistema não estava aberto para o argónio, quando da intrusão do Maciço Alcalino de Poços de Caldas.

6) Quanto à litologia o Maciço Sienitico da Pedra Branca apresenta composições semelhantes à rocha lamboanitica (gnaisse sienitico) de Piqueri, no Rio Grande do Sul,descrita por Picada (1966); ao sienito gnaisse da serra de Itiuba, no interior da Bahia, mencionado por Pedreira (1978), aos sienitos de S.Gonça 10, PA (Vandoros e Coutinho, 1966), e ao maciço sienitico ao Norte de Caldas, MG descrito por Wernick (1975). Salvo para a rocha de Piqueri as demais tem origem magmātica reconhecida. 


\section{VIII - AGRADECIMENTOS}

Ao Professor Doutor Josē Moacyr Vianna Coutinho, do Departamento de Mineralogia e Petrologia do Instituto de Geociências da Universidade de São Paulo, pela orientação desta dis sertação e assistência durante o Curso de Pós-Graduação;

Ao. Professor Doutor Heinz Ebert, pela orientação da fase inicial, por ter acompantiado atravēs de crīticas e suges tões a elaboração deste trabalho e pelo interesse que despertou em mim pela carreira cientifica;

Ao Conselho Nacional de Desenvolvimento Cientifi co e Tecnolögico (CNPq), pela concessão de Bolsas de Iniciação Cientîfica (Proc. 386/73) e Pōs-Graduação (Proc. 14687/74), que tornaram possĩvel a realização do presente trabalho;

Ao Departamento Nacional da Produção Mineral (DNPM), pela ajuda prestada por ocasião dos trabalhos de campo do Trabalho de Formatura de 1974, em convênio com a Faculdade de Filosofia, Ciências e Letras de Rio Claro;

Ao Centro de Pesquisas Geocronológicas da Univer sidade de São Pauto, nas pessoas do Professor Doutor Umberto $G$. Cordani e Professor Doutor Koji Kawashita, pela colaboração e orientação prestadas durante as anālises radiomētricas;

Aos Professores: Doutor Asit Choudhuri, Doutor Ebehard Wernick e Alberto Pio Fiori, do Departamento de Mineralo gia e Recursos Minerais do Instituto de Geociencias e Ciências E xatas da Universidade Julio de Mesquita Filho (UNESP) - Campus de Rio Claro; Doutor Jorge SiTva Bettencourt da Mineração Oriente Novo S.A. e Doutor Paulo Cesar Soares, consultor da Paulipetro S.A. e Mineropar S.A., que contribuiram na elaboração do pre sente trabalho, atravēs de sugestões, criticas e debates;

Ao Instituto de Geociēncias e Ciēncias Exatas,da Universidade Paulista Julio de Mesquita Filho (UNESP), que me proporcionou o ambiente necessário para o desenvolvimento das mi 
nhas atividades didäticas e de Pesquisa;

Ao Engenheiro Luis Vilar de Carvalho, Diretor da Companhia de Cimento Portland Rio Branco (PR), que me concedeu horas preciosas do expediente normal de trabalho, sem o qual seria impossível a realização do presente trabalho;

Ao Senhor Carlos Alberto de Oliveira, pelo excelente serviço de desenho;

A Senhora Claudete Salinas Franzosi, pelo presti moso serviço de datilografia;

A todos que direta ou indiretamente, participa ram na execução desta đissertação;

Meu muito obrigado. 
ALMEIDA, F.F.M. - 1964 - Fundamentos geolögicos do relevo paulis ta. In "Geologia do Estado de São Paulo". São Paulo. Secretaria da Agricultura, I.G.G. B01. nọ 41, pp. 169-263.

ALMEIDA, F.F.M.; HASUI, Y. e NEVES, B.B.B. - 1976 - The upper precambrian of South America. Bo1. I.G.U.S.P., Vo1.7,pp.4580 .

AMARAL, G.; CORDANI, U.G.; KAWASHITA, K. e REYNOLDS, J.H.- 1966 Potassium-argon dates of basaltic rocks from Southern Brazi1. Geoch. et Cosm. Acta, Vo1.30, pp. 159-189. Oxford.

ARTUR, A.C. - 1980 - Rochas Metamörficas dos arredores de Itapira-SP. IGUSP. Dissertação de Mestrado. $193 \mathrm{pp}$. (inēdita).

ARTUR, A.C.; WERNICK, E. e KAWASHITA, K. - 1979 - Dobramentos Su perimpostos na Região de Itapira (SP): Caracterização e cró nologia. Atas do II Simpōsio Regional de Geol. (Soc. Bras. Geol. - Nücleo de São Paulo), Vol.1, pp. 59-70.

BJORNBERG, A.J.S. - 1959 - Rochas clästicas do Planalto de Poços de Caldas. Fac.Fil.Ciênc.Letras, USP. Bol.237 (Geologia 18). pp.65-122.

BROGER, W.C. - 1920 - Die Eruptivgestaine des Kristianagebietes IV: Das Fenegebiet in Telemark, Norwegen.Videnskapsselskapa ta Skrifter, I (Mat. Naturv.) Klasse, 1920, 9. XII 408 pp.

CHOUDHURI, A.; EBERT, H.; WINTERS, A.A.M. - 1978 - Os metassedimentos e paragnaisses da região norte de Pouso Alegre, Sul de Minas Gerais. An. XxX Congr.Bras.Geo1., Recife pp.69-82.

CHOUDHURI, A.; FIORI, A.P.; WINTERS, A.A.M.; BETTENCOURT, J.S. e RODRIGUES, J.E. - 1978 - A note on small bodies of eclogite as inclusiones in hing grade gneisses, Nort of Pouso Alegre, Minas Gerais. Rev.Bras.Geociênc.Vol.8, nọ T, pp. 63-68.

CHRISTOFOLETTI, A. - 1970 - Anāilise Morfomētrica de Bacias Hidro gräficas do Planalto de Poços de Caldas. Tese de Livre- Docência. FFCL - Rio Claro. 
CLOOS, H. - 1923 - Das Batholithenproblem. Fortschr. Geol. und Pal., Helf 1 , no 80 .

CORDANI, U.G. e BITTENCOURT, I. - 1967 - Determinação de idade potāssio-argōnio em rochas do Grupo Açungui. An. XXI Congr. Bras.Ge01. Curitiba. pp. 218-233.

CORDANI, U.G. e KAWASHITA, K. - 1971 - Estudo geocronolögico pe10 mëtodo $\mathrm{Rb}-\mathrm{Sr}$ de rochas graniticas intrusivas no Grupo Açungui. An. XXV Congr.Bras.Geol. São Paulo. pp. 105-110.

CORDANI, U.G.; DELHAL, J. e LEDENT, D. - 1973 - Orogēneses superposēs dans le precambrian du Brésil Sud-Oriental. (Etate de Rio de Janeiro et de Minas Gerais). Rev. Bras.Geociênc. no $3, V_{01} .1, \mathrm{pp} .1-22$.

CORDANI, U.G.; HALPERN, M. e BERENHOLC, M. - 1974 - Comentärios sobre as determinações geocronológicas da Folha de Porto Alegre. In "Carta Geológica do Brasil ao Milionésimo. Folhas Porto Alegre (SH-22) e Lagoa Mirim (Si-22). Texto explicati vo", MME-DNPM, Brasilia, pp. 70-84.

COUTINHO, J.M.V. - 1959 - Guia da la. Excursão (São Paulo-Poços de (aldas) do XIII Congresso Brasileiro de Geologia, SP Sociedade Brasileira de Geologia, 12pp.

EBERT, H. - 1968 - Ocorrēncia de fäcies granuliticas no sul de Minas Gerais e Areas Adjacentes, em dependência da estrutura orogênica: Hipótese sobre sua origem. An. Acad.Bras. Ciênc. 40 (Sup1.). pp. 215-229.

EBERT, H. - 1971 - Os paraibides entre São João Del Rey (MG) e Itapira (SP), e a bifurcação entre Paraibides e Araixides. Soc. Bras.Geol. - Núcleo de São Paulo. Bol. Especial nọ 1 (Resumo das Comunicações do XXV Congr.Bras.Geo1.) pp. 117 178.

EBERT, H. - 1972 - Observações estruturais no contato basal dos sedimentos da bacia do Paraná. Ana is XXVI Congr.Bras. Geol. Belēm. Vol.1, pp. 153-157.

EBERT, H. - 1974 - O Grupo Eleutērio e a Falha de Jacutinga (Nor deste de São Pauío). Soc.Bras.Geol. Núcleo do Rio Grande do 
Sul. Bol. Especial nọ 1 (Resumo das Comunicações do XXVIII Congr.Bras.Geol.) pp. 726-730.

EBERT, H. e BROCHINI, M.F. - 1968 - Estudos Estratigräficos e Geocronolögicos no Escudo Cristalino Brasileiro. Ciēncia e Cultura 20, pp. 621-625.

ECKERMANN, H. - 1946 - The Alkaline District of Alnd Island. Sver. Geol. Undersokning, 36. $176 \mathrm{pp}$.

ELLERT, R. - 1959 - Contribuição a geologia do Maciço Alcalino de Poços de Caldas. Fac.Fil.Ciēnc.Letras., USP. Bol.237 (Geologia 18) 1-63 pp.

ELLERT, R.; BJORNBERG, A.J.S. e COUTINHO, J.M.V. - 1959 - Mapa geológico do Maciço Alcalino de Poços de Caldas. Dep.Geol. Paleont., Fac.Fil. Ciēn. Letras., USP, 1:75000.

FIORI, A.P. - 1979 - Geologia da Região de Pouso Alegre - Machado: Anälise Estrutural de Dobramentos Superpostos. Tese de Doutoramento - IGUSP (inēdita). $200 \mathrm{pp}$.

FIORI, A.P.; WERNICK, E.; CHOUDHURI, A.; SOARES, P.C. E BETTEN COURT, J.S. - 1980 - Evolução geolōgica da parte SW do Estado de Minas Gerais. (no prelo).

FRANCO, R.R. e COUTINHO, J.M.V. - 1957 - Charnockitos e Rochas Associadas no Municipio de Amparo e Socorro, Estado de São Paulo. An.Acad.Bras.Ciēnc. Vol.28, nọ 3, pp. 303-311.

GARCIA DE OLIVEIRA, A. - 1974 - Mineralização de urânio e molibdênio no planalto de Poços de Caldas, MG. - An. do XXVIII - Cong.Bras.Geol., vol.1, pp. 207-221.

GOMES, C.B.; COUTINHO, J.M.V. e OLIVEIRA, A.B. - 1966 - Pargasita em Dolomitos Metamörficos do Municipio de Tapiratiba, SP. An.Acad.Bras.Ciēnc. Vol. 38, pp. 39-46.

GOMES, C.B.; RUBERTI, E. e WERNICK, E. - 1976 - Caracterização quimica de feldspatos de rochas graniticas. An. Acad.Bras. Ciênc., Vol.48. no 3. pp. 445-452.

GUERRA, A.T. - 1969 - Dicionärio geolōgico-geomorfolögico-Fundação IBGE, $439 \mathrm{pp}$. 
GUIMARAES, D. - 1947 - Origem das rochas alcalinas - Int. Tecn. Ind. MG. Bo 1.5, pp. 1-104.

HAMA, M. e CUNHA, H.C.S. - 1977 - Considerações sobre a idade radiomëtrica da Formação Pouso Alegre e dos granitos póscambrianos da região Sul do Estado de Minas Gerais e Nordes te do Estado de São Paulo. Atas do I Simpósio de Geol. Regió nal (Soc.Bras.Geol. - Nücleo de São Paulo) pp. 48-58.

HASUI, Y. e HAMA, M. - 1972 - Geocronologia do Grupo São Roque pelo mëtodo potāssio-argônio. Rev. Bras. Geociênc. Vol.2, no 1. pp. 8-24.

HEINRICH, E.W. - 1965 - Microscopic Identification of Minerals. McGraw-Hill Book Company (New York). 414 pp.

LEONARDOS, Jr, O.H.; DUNHAM, A.C.; PIRES, F.R.M. E FORMAM, J. M. A. - 1971 - Nota sobre a Formação Pouso Alegre, An. Acad. Bras. Ciênc. Vol. 43 (e): 131-134.

LOCZY, L. e LADEIRA, E.A. - 1976 - Geologia Estrutural e Introdu ção à Geotectōnica. Editora Edgar Blucher Ltda. 528 pp.

MEHNERT, K.R. - 1968 - Migmatites and the origin of granitic rocks. Elsevier Pub. Comp., New York, 325 pp.

OLIVEIRA, M.A.F. de - 1973 - Petrologia das Rochas Metamōrficas da Região de São Josē do Rio Pardo (SP). Rev. Bras.Geociên. Vo1.3 no. 2, pp. 257-278.

OLIVEIRA, M.A.F.de e ALVES, F.R. - 1974 - Geologia e Petrografia da Região de Caconde (SP). Anais do XXVIII Congresso Brasileiro de Geologia. Porto Alegre, Vol.5, pp. 133-143.

OLIVEIRA, M.A.F. de e ALVES, F.R. - Wollastonita em Associações Cálcicas da Fäcies Granulito, Caconde, SP. Rev. Bras. Geociênc. Vol.6 nọ 1, pp. 43-52. 
OLIVEIRA, M.A.F. de e HYPOLITO, R. - 1973 - Rochas Calco-silicáticas da Região de São Josē do Rio Pardo, SP. An.XXVII Congr. Bras.Geol., Vol.1, pp. 193-200, Aracaju.

PENALVA, F. e WERNICK, E. - 1973a - Feições estruturais de migmati tos ao Norte e Sul da Falha de Jacutinga, Leste do Estado de São Paulo. Ciência e Cultura, 25: 183.

PENALVA, F. e WERNICK, E. - 1973b - Compartimentação tectōnica em parte do Pré-Cambriano Paulista. Soc.Bras.Geol. - Nücleo da Bahia. Boletim Especial nọ 1 (Resumo das Comunicações do XXVII Congr.Bras.Geol.), Aracaju. pp. 128-129.

PEDREIRA, A. - 1978 - Roteiro das excursões do XXX Congr.Bras.Geol. p.22 - Recife - SBG - Nücleo Nordeste.

PICADA, R.S. - 1966 - Sobre a ocorrência de rochas lamboantiticas no Complexo Encruzilhada, R.G.S. - Escola de Geologia UFRGS. Notas e Estudos, vol.1, no 2. pp. 9-13.

PIRES; F.R.M.; LEONARDOS Jr, O.H. e PARENTI COUTO, J.G. - 1970-Gon ditos na Região de Pouso Alegre (MG). Min. e Met. 52 (312), pp. 237-239.

RODRIGUES, J.E. - 1976 - o falhamento transcorrente de Jacutinga.Dissertação de Mestrado - IGUSP (inëdita). $44 \mathrm{p}$.

SOARES, P.C. (Coordenador) - 1976 - Projeto Caldas II. Convēnio FFCL - DNPM. Relatōrio. Depto. Geociēnc. Rio Claro.

SOARES, P.C. e FIORI, A.P. - 1976 - Lögica e sistemätica na anālise e interpretação de fotografias aēreas em geologia. Not. Geomorf. Campinas. Vol.16, nọ 32. pp. 71-104.

TORQUATO, J.R. - 1974 - Geologia do SW de Moçãmedes e suas relações com a evolução tectōnica da Angola. Tese de Doutoramen to - IGUSP - (inēdita). $234 \mathrm{pp}$.

ULBRICH, H.H.G.J.; ULBRICH, M.N. e BAGNOLI, E. - 1978 - Estrutura e petrografia do lujaurito de Poços de Caldas, MG - XXX Conq. 
Bras.Geo1. Res.Com. pp. 92.

VANDOROS,P. e COUTINHO, J.M.V. - 1966 - Estudo geolögico e geocro nológico da ārea de São Gonçalo, Paraiba. Bol. SBG. v.15, no 4. pp. 15-26.

VANDOROS, P. e FRANCO, R.R. - 1969 - Determinação de idade de gra nitos da região de Mogi das Cruzes, São Paulo, pelos mëtodos K-Ar e Rb-Sr-An.Acad.Bras.Ciēnc. Vol. 38, no 2. pp. 289 292.

WERNICK, E.- 1967 - A geologia na região de Amparo (Leste do Esta do de São Paulo). FFCL - Rio Claro. Tese de Doutoramento. $235 \mathrm{pp}$.

WERNICK, E. - 1972a - Sobre a Ocorrência de Rochas Calco-silicata das nas Proximidades de Duas Pontas, Municipio de Arcadas, Leste do Estado de São Paulo. Ciēnc. e Cult., Vol.24 nọ 4, pp. 358-367.

WERNICK, E. - 1972b - Granitos Pörfiros dos Arredores de Serra Negra, Valinhos e Amparo e suas Relações com o Maciço de Morungaba, Leste do Estado de São Paulo. Rev. Bras.Geociēnc. Vol.2 no 2, pp. 129-138.

WERNICK, E. - 1975 - Projeto Caldas I. Convēnio FFCL - DNPM. Rela törio. Depto. Geociênc. Rio Claro.

WERNICK, E. - 1977 - (Coordenador) "Projeto Ouro Fino", Convênio FFCL - DNPM. Relatōrio. Depto. Geociēnc. Rio Claro.

WERNICK, E. - 1978a - Contribuição à estratigrafia do Prē- Cambriano do Leste do Estado de São Paulo e áreas vizinhas.Rev. Bras.Geociênc., Vol. 8, nọ 3, pp. 206-216.

WERNICK, E. - 1978b - Contribuição à geologia do Maciço de Guaxupé, SP e MG. An. Acad.Bras.Ciēnc. Vol.50, nọ 3. pp. 337-352.

WERNICK, E. e ARTUR, A.C. - 1974 - Petrofabric de Migmatitos dos arredores de Amparo, SP. Rev. Bras.Geociēnc., Vol. 4, no 1. pp. $27-39$. 
WERNICK, E. e FERNANDES, N.A. -1972 - Triclinicidade de feldspatos potássicos de rochas graniticas do Maciço de Morungaba, SP. An. XXVI Congr.Bras.Geol., Belēm. Vol.1 pp. 51-56.

WERNICK, E. e FIORI, A.P. - 1979 - Contribuição à geologia da borda sul do Craton de São Francisco. (no pre?o).

WERNICK, E. e GOMES, C.B. - 1977 - Geoquimica de maciços granïti cos da região do Ribeira. Parte III: considerações petrológicas. An.Acad.Bras.Ciēnc. Vol.49, nọ 1. pp. 157-169.

WERNICK, E. e PENALVA, F. - 1973 - As relações entre os Grupos Amparo e Itapira (SP). Soc. Bras.Geol. Nücleo da Bahia. Boletim Especial no 1 (Resumo das comunicações do XXVII Congr. Bras.Geo1.). pp. 116-117.

WERNICK, E. e PENALVA, F. - 1974a - Migmatização e feldspatiza ção de charnockitos e granulitos no Leste paulista e sul de Minas Gerais. An. do XXVIII Conqr.Bras.Geol., Porto Alegre. Vo1. 5. pp. 155-160.

WERNICK, E. e PENALVA, F. - 1974b - Depösitos molassöides da For mação Eleutērio, SP - MG. Soc. Bras.Geol. Nücleo Rio Grande do Sul. Boletim Especial no 1. (Resumo das Comunicações do XXVIII Congr.Bras.Geol.). pp. 723-726.

WERNICK, E. e PENALVA, F. - 1978 - Contribuição ao conhecimento das rochas granitöides do sul do Brasil. Rev. Bras.Geociênc. vol. 8, no 2. pp. 113-133.

WERNICK, E. e PENALVA, F, - 1980 - O Grupo Pinhal na Região Nordeste do Estado de São Paulo e Areas Vizinhas do Estado de Minas Gerais. Bol. IGUSP., Vol. 11, pp. 1-20.

WERNICK, E.; FERNANDES, N.A. e ALMEIDA Jr, N.F. - 1976a - Gonditos de Socorro e Itapira, SP. Min. Metal., Vol. 39 (372) : 16-21 pp.

HERNICK, E.; PANTOJA, J.L. e NICOLA, J.P. - 1976C - Megacristais do maciço granitico de Socorro (SP e MG). Soc.Bras. Geol. 
Nücleo de Minas Gerais. Boletim Especial no 1. (Resumo das. Comunicações do XXIX Congr.Bras.Geol.). pp. 329.

WERNICK, E.; FIORI, A.P.; BETTENCOURT, J.S. E CHOUDHURI, A. -1979A tectónica rigida do fim do Ciclo Brasiliano e sua implicação na estruturação da borda $S$ e $S W$ do Craton do São Francis co: Tentativa de um modelo preliminar. (no prelo).

WERNICK, E.; OLIVEIRA, M.A.F. de; KAWASHITA, K.; CORDANI, U.G. e DELHAL, J. - 1976b - Estudo geocronolögico pelo método RbSr em rochas do Bloco Jundiai e Regiões adjacentes.Rev. Bras. Geociênc., Vol. 6, nọ 1. pp. 125-135.

WINTERS, A.A.M - 1975 - A Geologia da Serra da Pedra Branca; Cal das Andradas (MG). Relatório Final da Bolsa de Iniciação Cientifica $\mathrm{CNPq}$ (inēdito). 


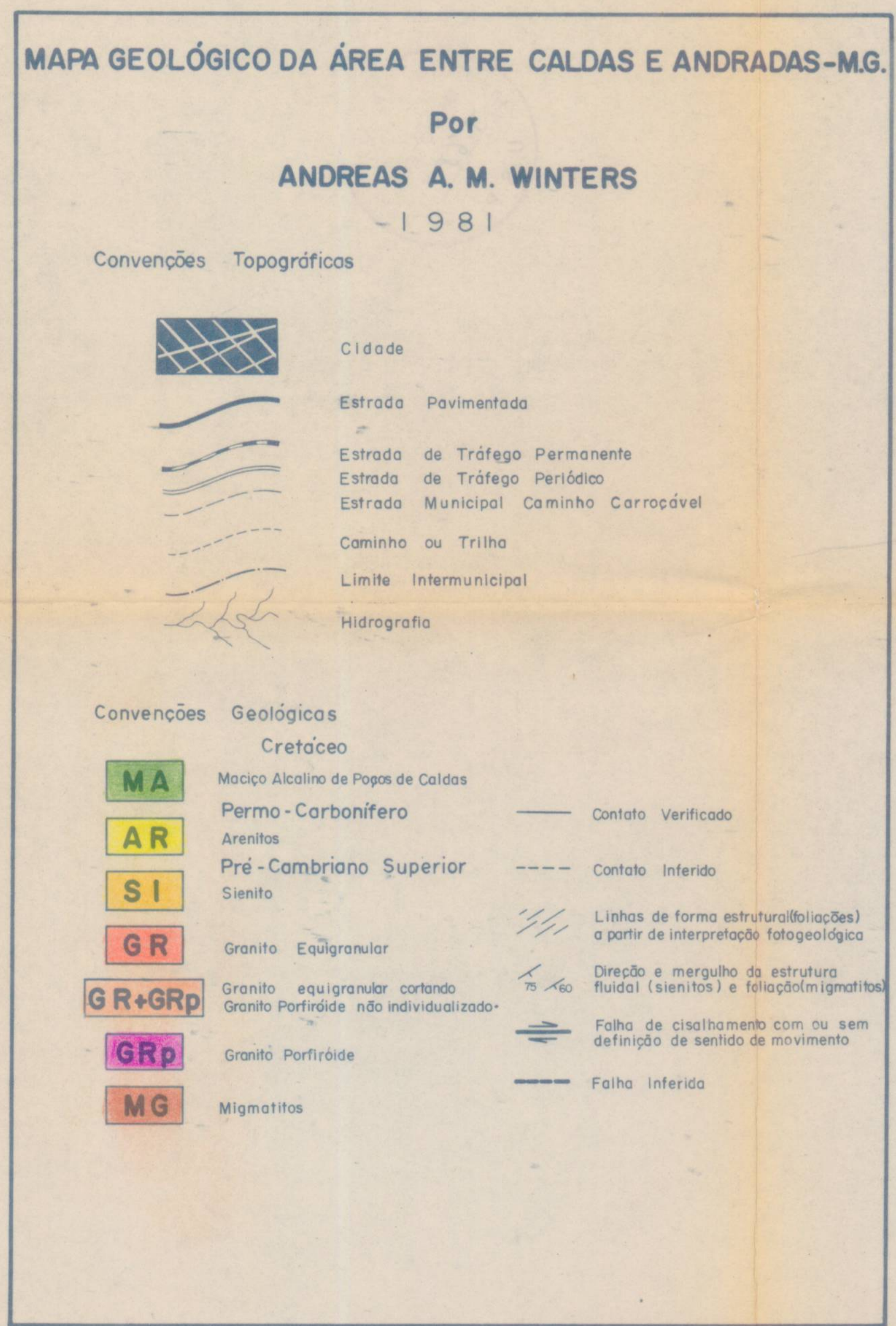

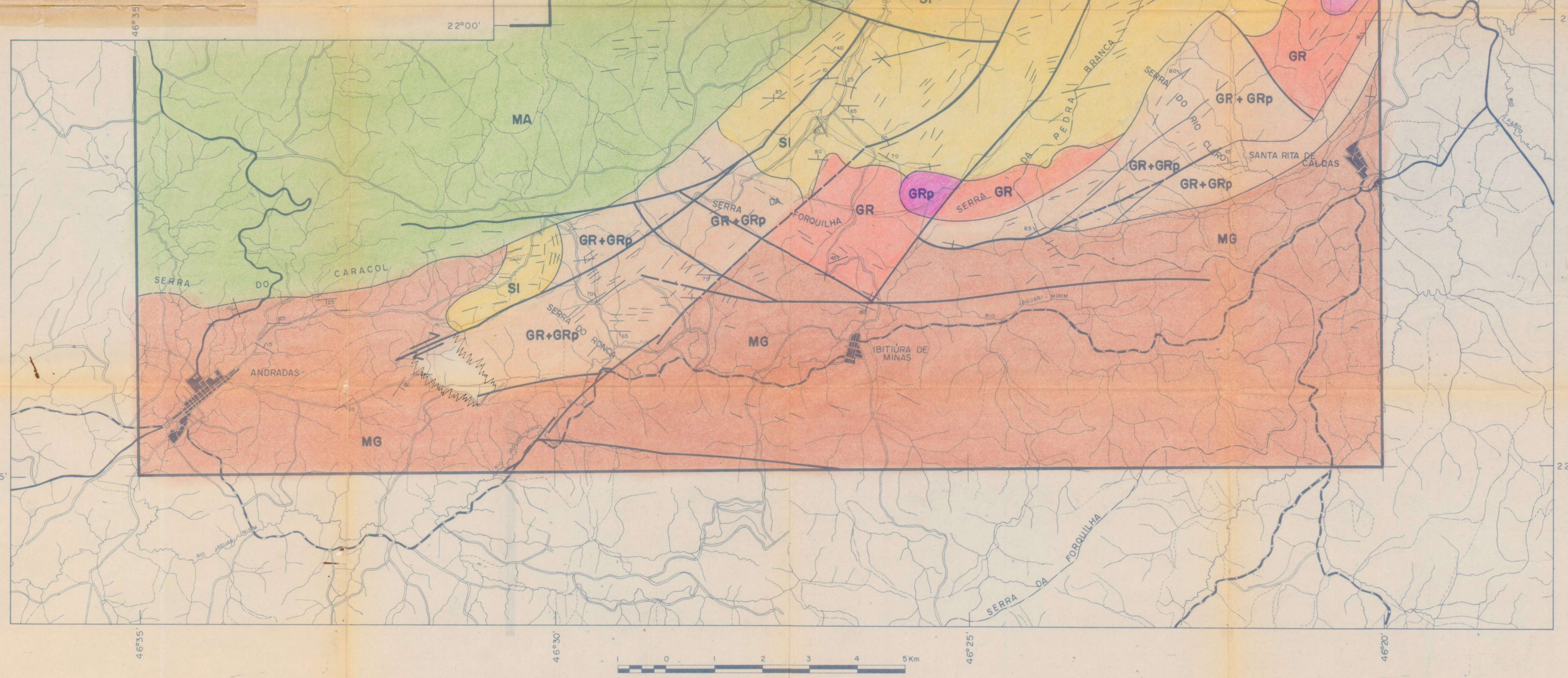




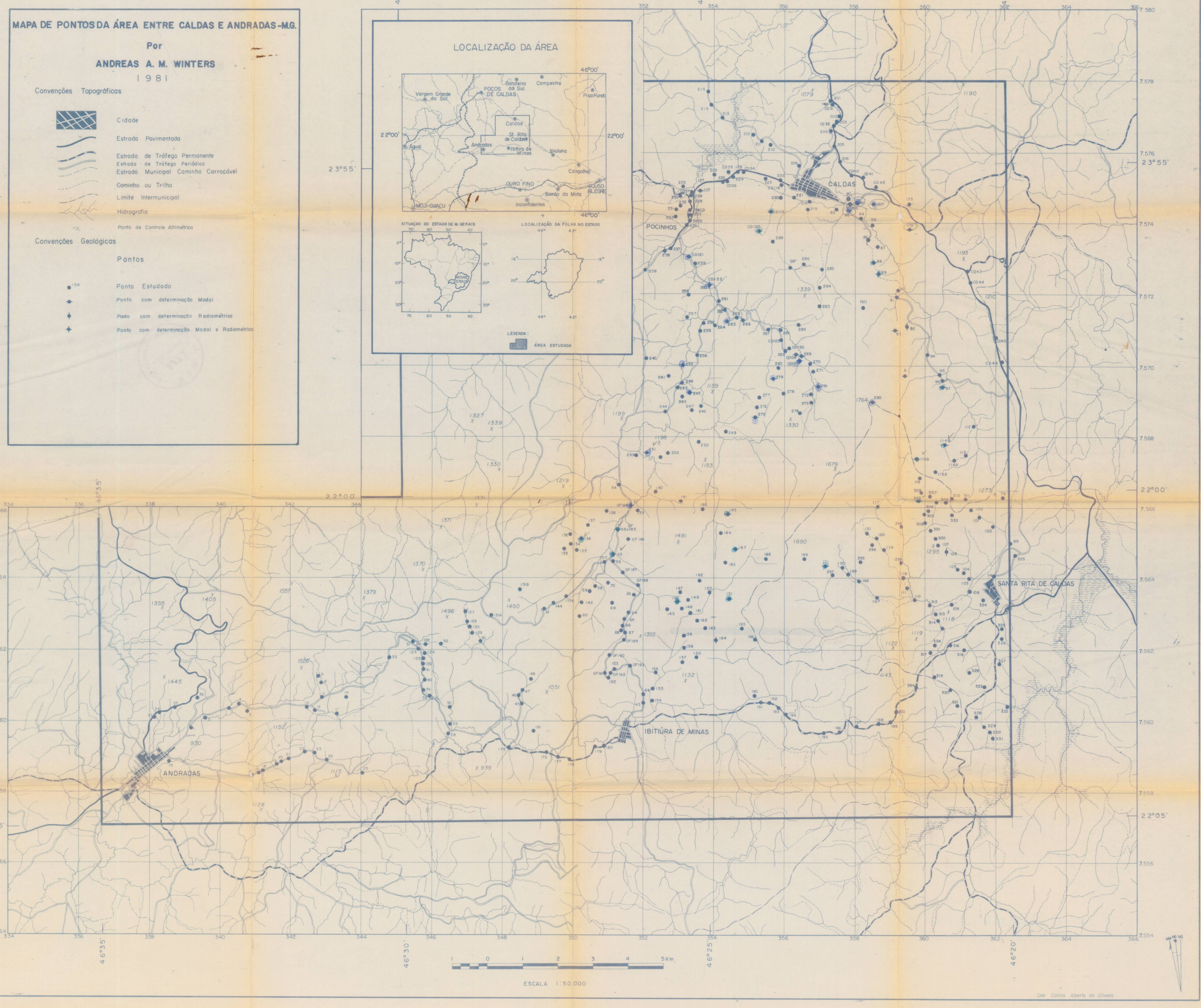

